PNL-3465

UC-70

\title{
Annual Report on the Development and Character- ization of Solidified Forms for Nuclear Wastes, 1979
}

\author{
L. A. Chick \\ G. L. McVay \\ G. B. Mellinger \\ F. P. Roberts
}

December 1980

Prepared-for the U.S. Department of Energy under Contract DE-AC06-76RLO 1830

Pacific Northwest Laboratory Operated for the U.S. Department of Energy by Battelle Memorial Institute 
NOTICE

This report was prepared as an account of work sponsored by the United States Government. Veither the United States nor the Department of Energy. nor any of their employees, nor any of their contractors. subcontractors, or their employees, makes any warranty, express or implied, or assumes anv legal liability or responsibility for the accuracy. completeness or usefulness of any information, apparatus, product or process disclosed, or represents that its use would not infringe privately owned rights.

The views. opinions and conclusions contained in this report are those of the contractor and do not necessarily represent those of the United States Government or the United States Department of Energy.

PACIFIC NORTHWEST LABORATORY

operated by

BATTELLE

for the

UNITED STATES DEPARTMENT OF ENERGY

Under Contract DE-AC06-76RLO 1830

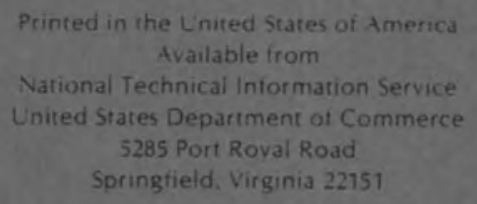

Price: Printed Copvs. $\therefore$ Microfiche $\$ 3.00$

-Pages Selling Price

$\begin{array}{ll}001-025 & \$ 4.00 \\ 026-050 & \$ 4.50 \\ 051-075 & \$ 5.25 \\ 076-100 & \$ 6.00 \\ 101-125 & \$ 6.50 \\ 126-150 & \$ 7.25 \\ 151-175 & \$ 9.00 \\ 176-200 & 59.00 \\ 201-225 & \$ 9.25 \\ 226-250 & 59.50 \\ 251-275 & 510.75 \\ 276-300 & 511.00\end{array}$




\section{8}

ANNUAL REPORT ON THE DEVELOPMENT

AND CHARACTERIZATION OF SOLIDIFIED

FORMS FOR NUCLEAR WASTES, 1979
L. A. Chick
G. L. McVay
G. B. Mellinger
F. P. Roberts

December 1980

Prepared for

the U.S. Department of Energy

under Contract DE-AC06-76RLO 1830

Pacific Northwest Laboratory

Richland, Washington 99352 
Although the authors listed on the cover of this report were the primary contributors, the following PNL staff members also contributed by writing portions of the report and reviewing the final draft.
D. J. Bradley
J. M. Rus in
C. Q. Buckwalter
J. W. Shade
W. J. Gray
G. L. Tingey
Y. B. Katayama
J. W. Wald
R. 0. Lokken
W. J. Weber
R. P. May
J. H. Westsik, Jr. 


\section{ABSTRACT}

This annual report on the development and characterization of sulidified forms for nuclear wastes represents a major continuing effort by Pacific Northwest Laboratory (PNL) to understand the chemical composition, process conditions, and long-term behaviors of various nuclear waste forms. Major research and experimental findings from seven research programs are reported. Extended figure and table captions provide brief technical summaries of the findings. 


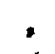

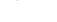


SUMMARY

Development and characterization of solidified nuclear waste forms is a major continuing effort at Pacific Northwest Laboratory (PNL). Contributions from seven programs directed at understanding chemical composition, process conditions, and long-term behaviors of various nuclear waste forms are included in this report. The major findings of the report are included in extended figure captions that can be read as brief technical summaries of the research, with additional information included in a traditional narrative format.

Waste form development proceeded on crystalline and glass materials for high-level and transuranic (TRU) wastes. Leaching studies emphasized new areas of research aimed at more basic understanding of waste form/aqueous solution interactions. Phase behavior and thermal effects research included studies on crystal phases in defense and TRU waste glasses and on liquid-liquid phase separation in borosilicate waste glasses. Radiation damage effects in crystals and glasses from alpha decay and from transmutation are reported.

\section{WASTE FORM DEVELOPMENT}

Alternative Waste Forms

A scoping study demonstrated that silica and bentonite clay additives improve the properties of typical TRU incinerator ash and blended wastes.

Comparison of the leaching behavior, volatility, and mechanical strength of eight highlevel waste forms showed that supercalcine, glass, and glass ceramic materials can be grouped together as highly durable waste forms; that sintered calcine and concrete materials have low durability; and that hot pressing or the addition of frit to calcine produces intermediate durability waste forms. Controlled devitrification of basalt glass resulted in a glass ceramic material with improved chemical durability.

Coating supercalcine pellets with pyrolytic carbon $(\mathrm{PyC})$ and/or alumina resulted in protective barriers that were resistant to leaching. PyC coatings can successfully be applied at low temperatures. The usefulness of carbon as a protective coating was demonstrated in experiments that showed that graphite reacts several orders of magnitude more slowly in water than do glasses, supercalcine, alumina, zirconia, granite, and mullite.

\section{Glass Waste Forms}

Development of empirical models to predict glass properties in an 11-component glass composition field yielded information on effects of nuclear waste glass oxides on viscosity, volatility, and crystalline phase behavior. 0xides that cause the viscosity to increase tend to cause the volatility to decrease. Chromium, nickel, iron, and zinc promote crystallinity in air-quenched samples whereas alkalis, alkaline earths, and silicon inhibit crystallinity in such samples. Nickel and zinc increased crystallinity most in slow-cooled specimens whereas boron was the most effective in reducing crystallization.

Borosilicate glasses for immobilization of TRU ash wastes were developed and characterized. Of six oxides present in the widely variable ash compositions, $\mathrm{Cr}_{2} \mathrm{O}_{3}$ and $\mathrm{NiO}$ had the 
lowest solubilities and $\mathrm{Fe}_{2} \mathrm{O}_{3}$ and $\mathrm{TiO}_{2}$ had the highest solubilities in a base glass.

Increasing the content of ash waste in a base glass causes higher viscosity and electrical resistivity but results in improved chemical durability.

Krypton-85 Gas Waste Forms

Sputter-deposited metal and sintered porous glass show promise as solidified waste forms for krypton-85. Multicomponent amorphous metals containing as much as 10 at.\% krypton were produced. Both the sputtered metals and the glass show excellent krypton retention with less than $1 \%$ of the krypton being released during a 10-year period at temperatures of 300 and $420^{\circ} \mathrm{C}$, respectively.

\section{LEACHING INVESTIGATIONS}

Fundamental Leaching Phenomena

Studies of fundamental leaching phenomena received increased emphasis. It was reported that $\mathrm{H}^{+}$rather than $\mathrm{H}_{3} \mathrm{O}^{+}$is the water species that ion exchanges with alkali metal ions in glass. It was demonstrated that an electrical potential is generated on the surface of glass and that the magnitude of the potential is proportional to the leach rate. Application of a reverse or "bucking" potential was shown to retard leaching.

\section{Leaching Environment Effects}

Leach rates of glass after 3 years in a static test were 5 times slower than leach rates after the same period in a dynamic test in which the solution was changed every 6 months. Release rates of most actinide elements were slower than release rates of silicon from glass. of five leachants, sodium bicarbonate solution was found to attack glass most aggressively while deionized water and salt brine resulted in the lowest release rates. Leach rates of fully radioactive glass were found to be unchanged after 8 years of storage in a dry environment prior to initiation of leaching.

\section{Comparison of Waste Forms}

Comparison of leaching behavior of waste forms showed that a supercalcine, a borosilicate glass, and a synroc leached at essentially similar rates over the temperature range of 25 to $350^{\circ} \mathrm{C}$. Cesium leached approximately 100 times faster from spent fuel than from 8-year-old fully radioactive glass. Plutonium leach rates from Portland cement and polyester-styrene TRU waste forms were two to three orders of magnitude lower than those for urea-formaldehyde materials.

\section{Waste Package Leaching}

Initial results from waste package leaching studies confirm that such systems involve complex reactions. Cesium, potassium, and molybdenum tended to build up in solution while calcium and strontium tended to precipitate in salt-bearing waste package tests. 0xidizing conditions caused uranium to migrate from glass into adjacent granite in another test. 


\section{PHASE BEHAVIOR AND THERMAL EFFECTS}

Phase behavior studies produced information about crystallinity in TRU and defense waste glasses. Addition of aluminum to a TRU waste glass was found to increase spinel crystal formation by displacing iron from the glass network. The roles of aluminum, manganese, nickel, iron, lithum, and sodium in crystal phase behavior of three defense waste borosilicate glasses were studied in detail. The glass containing the transition metals and lithium produced the most favorable microstructure after long-term annealing.

Liquid-liquid phase separation occurred in all borosilicate waste glasses studied. Phase separation is believed to be detrimental to chemical durability although the magnitude of this effect has not yet been determined. Addition of carbon to a glass melt reduced the extent of phase separation.

\section{RADIATION EFFECTS}

Radiation damage studies were performed on a number of specific crystalline phases and candidate waste forms. Internal alpha-recoil and external alpha bombardment studies suggest that lattice expansion resulting from alpha bombardment in nonactinide-containing waste phases can be greater than that occurring in actinide-containing phases. In addition, the results establish that alpha and alpha-recoil damage in high-level nuclear waste solids cannot be accurately simulated by fission damage studies.

Annealing of radiation damage was found to occur over similar temperature ranges for five borosilicate waste glasses. Release of stored energy proceeded in a single stage and was complete at $360^{\circ} \mathrm{C}$ for all the glasses.

An accelerated study of the effects of transmutation of cesium to barium on glasses, pollucite, and supercalcine was begun by irradiating the test samples in a reactor to produce ${ }^{134} \mathrm{Cs}$, which has a 2-year half-life. X-ray diffraction and microscopy as we 11 as leach testing and density measurements will be performed on the samples. 


\section{CONTENTS}

ACKNOWLEDGMENTS

ABSTRACT

SUMMARY

INTRODUCTION

WASTE FORM DEVELOPMENT - G. B. Mellinger, ed.

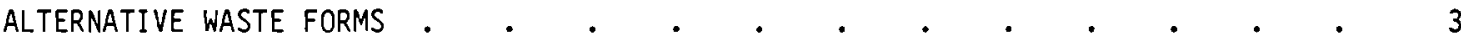

TRU Waste Forms - J. M. Rusin . . . . . . . . . . . 3

Comparative Study - J. W. Wald, J. M. Rusin, R. O. Lokken, and J. W. Shade . 5

Basalt Glass Ceramics - R. 0. Lokken . . . . . . . . . . . . 10

Coated Particle Development - J. M. Rusin, W. J. Gray, and J. W. Shade . 12

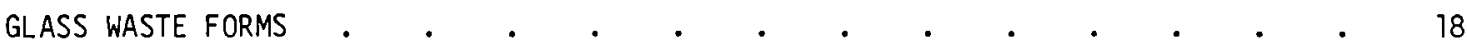

Glass Composition Study - L. A. Chick and G. B. Mellinger . . . . 18

TRU Glass Development - G. B. Mellinger . . . . . . . . . . 23

KRYPTON-85 CONTAINING SOLID WASTE FORMS - G. L. Tingey . • • • • • $\quad 24$

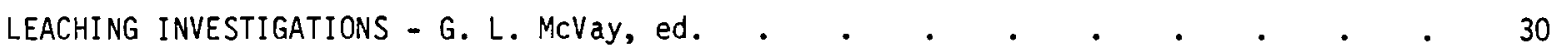

FUNDAMENTAL LEACHING PHENOMENA - G. L. McVay • • • • • • • • • $\quad$ - 30

LEACHING ENVIRONMENTAL EFFECTS - D. J. Bradley, J. H. Westsik, and G. L. McVay . 35

COMPARISON OF WASTE FORMS - J. H. Westsik and Y. B. Katayama . . . . 43

WASTE PACKAGE LEACHING - J. W. Shade . . . . . . . . . . 46

PHASE BEHAVIOR AND THERMAL EFFECTS - L. A. Chick, ed. . . . . . . . . . 53

EFFECTS OF ALUMINUM AND IRON ON SPINEL FORMATION IN WASTE GLASSES - G. B. Mel1inger 53 DEVITRIFICATION BEHAVIOR OF THREE DEFENSE WASTE GLASSES - R. P. MaY • • $\quad 55$

LIQUid-Liquid PHASE SEPARATiON - L. A. Chick and M. Tomozawa . . . $\quad 59$

RADIATION EFFECTS - F. P. Roberts, ed. . . . . . . . . . . . . . . 63

RADIATION DAMAGE IN CRYSTALLINE CERAMICS - W. J. Weber . . . . . . $\quad 63$

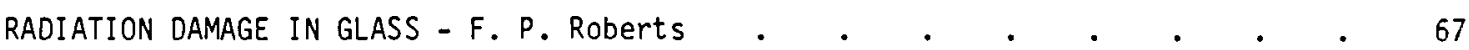

EFFECTS OF TRANSMUTATION ON WASTE FORMS - W. J. GRAY.$\quad \cdot \quad \cdot \quad \cdot \quad \cdot \quad \cdot 68$

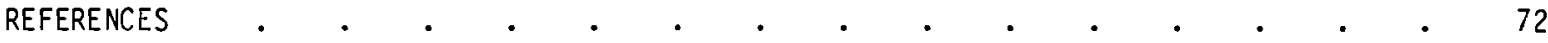


1 Solution Analys is of Leachate from TRU Waste Forms Containing Ash . . . $\quad$. 5

2 Volatility Measurements for Selected Comparative Study Samples . . • . $\quad$. 9

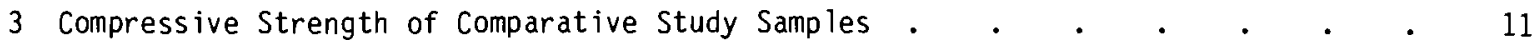

4 Effect of Leaching on the Surface of a Basalt Glass Ceramic . . . . . $\quad$. 13

5 Low-Temperature PyC CVD Coating on Simulated Nuclear Waste Pellets . $\quad$ • 15

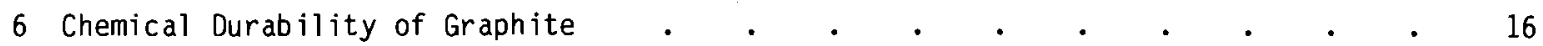

7 Effects of Glass Components on Viscosity at $1250^{\circ} \mathrm{C}$. $\quad . \quad$. . . . . $\quad$. 20

8 Effects of Glass Components on Volatility at $1300^{\circ} \mathrm{C} \quad \ldots \quad$. $\quad . \quad . \quad . \quad . \quad 21$

9 Effects of Glass Components on Crystallity After Air Quenching and Slow Cooling . 22

10 Electrical Resistivity and Viscosity of Glass $79-160$ at $1050^{\circ} \mathrm{C}$ as a

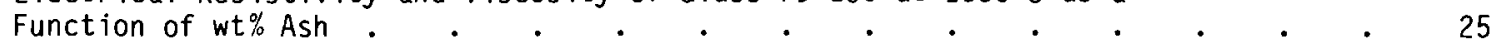

11 Leaching of Glass 79-160 as a Function of wt\% Ash . . . . . . . . . . $\quad$. 26

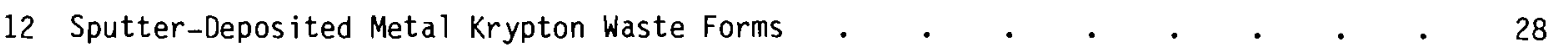

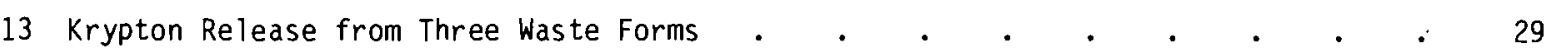

14 Ion Exchange of Hydrogen Species with Sodium in a Simple Glass . $\quad . \quad$ - $\quad 31$

15 Phenomena of Electrical Surface Potentials on Glass During Leaching . $\quad$ • $\quad 32$

16 Measurement of $\mathrm{pH}$ Versus Time Near and Away from the Glass Surface . $\quad$ • 36

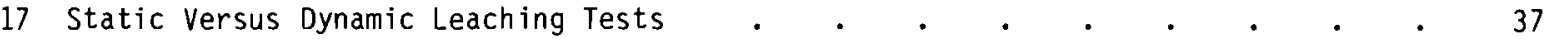

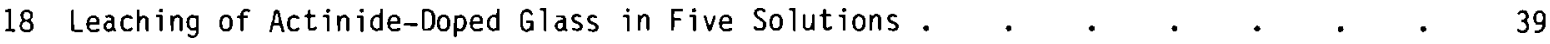

19 Actinide and Technetium Releases from Glass $76-68$ Leached in $150^{\circ} \mathrm{C}$ Deionized Water 42

20 Comparison of Three Leaching Techniques on 8-Year-01d Radioactive Waste Glass $\quad 44$

21 Leaching of Glass, Supercalcine, and Synroc as a Function of Temperature $\quad$ • 45

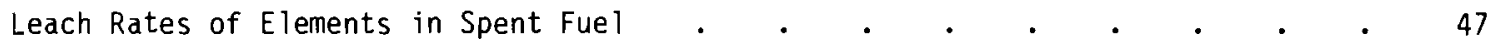

Leaching of Plutonium from Three TRU Ash Waste Forms in Five Leachants . . $\quad$. 49

Effect of Iron and Aluminum on Formation of Spinel Crystals in a Glass . $\quad . \quad 55$

Crystal Phases Formed In Three Defense Waste Glasses During Two Heat Treatments $\quad 57$

27 Phase Yield Curves for 4-Day Anneals of Three Defense Waste Glasses . $\quad$ - 58

28 Liquid-Liquid Phase Separation in Reference Nuclear Waste Glasses . . $\quad . \quad 61$

29 Reduction of Dispersed Phase Volume Fraction by Adding Carbon _ . $\quad$ - $\quad$. 62

30 Radiation Damage in Crystalline Phases from Alpha Bombardment by an External Source 65 
31 Recovery of Radiation Damage in Crystalline Phases by Thermal Annealing . $\quad 66$

32 Comparison of Lattice Parameter Change Produced by Three Irradiation Sources

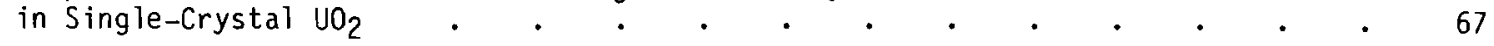

33 Recovery from Radiation Damage in Curium-Doped Borosilicate Glasses $\quad$ • $\quad$ • 69 
1 Bulk Density and Crystalline Phases Present in Waste Form Samples Used in Comparative Study .

2 Leaching Behavior of Comparative Study Waste Forms . . . . . . . 8

3 Leaching Behavior of Coated Supercalcine Multibarrier Waste Forms . . . . 14

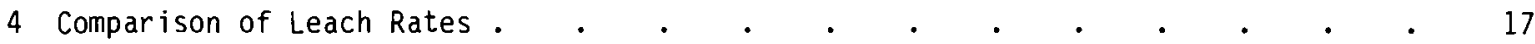

5 Glass Composition Study Test Matrix . . . . . . . . . . . . . 19

6 Solubility Limits of Various TRU Waste Oxides in a Representative

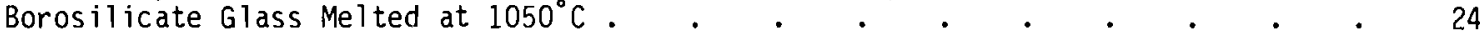

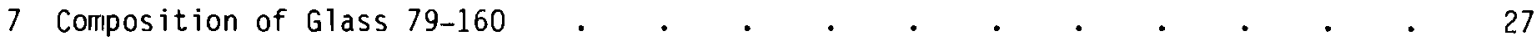

8 Comparison of Incremental Leach Rates of Elements for Each Solution Type . $\quad 48$

9 Results of the Effects of Solution Type on Each Element . . . . . . . 48

10 Brine Composition from Waste Package Tests . . . . . . . . . . 51

11 Composition of Base Glass Used in Spinel Formation Study . . . . . . $\quad 55$

12 Savannah River Laboratory Simulated Waste Glass Compositions . . . . . 56

13 Tests Completed or Under Way in Radiation Damage . . . . . . . . . . 64

14 Experimentally Determined Constants for Damage Ingrowth Expression and the Predicted Change in Unit Cell Volume at Saturation . . . . . . .66

15 Constants $A$ and $B$ in Alpha Decay Damage Expression and Density Change at Saturation 68 


\section{INTRODUCTION}

The safe handling, packaging, transport, storage, and disposal of nuclear waste are major concerns of industry, government, and the public. For the past decade, the U.S. Department of Energy (DOE) has funded projects to examine the following general areas of nuc lear waste research:

- solidification of waste

- examination of the behavior of waste in both original and solidified forms and under varying chemical and environmental conditions

- conversion of waste to a form that can be transported safely from the source to a repository

- examination of the potential for safe, long-term storage.

Nuclear waste management is a term that refers to an overall, coordinated effort to examine the problems associated with safe storage and/or disposal of nuclear waste. Presently, nuclear waste management is the largest single research and development (R\&D) activity at Pacific Northwest Laboratory (PNL). (a)

This is the fourth annual report that has been prepared to summarize PNL R\&D activities on solidified waste forms. The first and second annual reports (Mendel et al. 1977; Ross et al. 1978) were prepared as a result of the Program Plan for the Comprehensive Characterization of Solidified High-Level Wastes issued in late 1975 (Mendel et al. 1975). These first two reports focused primarily upon the characterization of commercial waste glasses. The third annual report (Ross and Mende1 1979) was expanded to include more waste materials, including defense waste glasses, commercial waste glasses, spent fuel, and alternative waste forms. Data from these first three reports were compiled in a comprehensive report (Mendel 1978).

The scope of this year's report has been broadened to include waste form development and characterization data generated under seven research programs. These programs and their general objectives are:

- High-Level Waste Immobilization Program (HLWIP), D. E. Larson, Program Manager

The objective of the HLWIP is to develop and demonstrate a technology base for converting existing and potential future high-level waste to a suitable form and packaging it for disposal in a repository. The waste form emphasized by the program is borosilicate glass.

- Waste Rock Interaction Technology Program (WRIT), R. J. Serne, Program Manager

WRIT's objective is to develop the necessary tests, data, and predictive capability on the release and subsequent geochemical interactions of radionuclides with engineered barriers and natural geologic media to predict the concentration and nature of species of the radionuclides in ground waters potentially flowing through waste repositories.

(a) Operated for DOE by Battelle Memorial Institute. 
- Alternative Waste Forms Program (AWFP), J. M. Rusin, Program Manager

The mission of AWFP is to develop and evaluate selected processes and waste forms as alternatives to the reference borosilicate glass process for immobilizing high-level radioactive liquid wastes. Specific waste form technologies being developed are coatings and matrices that are included in the multibarrier concept.

- Transuranic Waste Immobilization Program (TRUWIP), C. R. Palmer, Program Manager

The objective of the TRUWIP is to conduct a comparative assessment of alternative immobilization technologies for selected transuranic (TRU) wastes. One or more systems will be recommended for development and demonstration to begin in fiscal year (FY) -1982.

- Krypton Solidification Program (KSP), G. L. Tingey, Program Manager

KSP's objective is to investigate methods of immobilization of krypton in sputter-deposited metals and low-density glasses and to characterize the resulting solid products.

- Radiation Damage in Ceramics Program, Sponsored by the Office of Basic Energy Sciences (BES), DOE, W. J. Weber, Principal Investigator

The purpose of this program is to obtain a fundamental understanding of ioninduced radiation damage in nonmetallic solids.

- Leaching of Glass and Ceramics Program, Sponsored by BES, DOE, G. L. McVay, Principal Investigator

The objective of this BES program is to gain a basic understanding of ceramic materials degradation and ionic release while in contact with aqueous solutions. Progress in HLWIP, WRIT, AWFP, TRUWIP, and KSP is now reported collectively on a quarterly basis; the most recent report is PNL-3000-5 (Platt and Powell June 1980). Contributions from the seven programs have been combined into four sections in this annual report:

- Waste Form Development

- Leaching Investigations

- Phase Behavior and Thermal Effects

- Radiation Effects

Most of the figures and tables are accompanied by extended captions. These captions briefly explain the results and the implications of those results to nuclear waste management. 


\section{WASTE FORM DEVELOPMENT}

Waste form development at PNL has included crystalline ceramics, cement, and glass. Various coatings for multibarrier waste forms have also been studied. In addition, solidified forms for containment of krypton gas have been developed. Although later sections of this report deal with specific properties studies in detail, some property data are included in this section for analysis of waste forms under development.

The properties monitored in waste form development are predominantly related to the ability of the waste form to isolate radioactive materials from the environment. Release by dispersions of fine-size particulates, volatility of radionuclides in a transportation-related fire, and leaching are three scenarios on which the experimental programs have focused. Some properties related to processing of the waste form are also reported. Further details about test methods and their application to waste form development may be found in previous annual reports.

\section{ALTERNATIVE WASTE FORMS}

Crystalline alternative waste forms have received a great deal of attention in recent years, and they have a number of favorable features that recommend them for nuclear waste encapsulation. They may be made with high chemical durability to minimize the risk of longterm release of radioactive materials, and they may be thermodynamically stable materials that will minimize phase changes that might occur in the waste form if elevated temperatures are experienced in the waste repository or in a transportation accident. Concrete waste forms can accept a great deal of waste variation and do not require high-temperature processing.

Several programs have explored these types of waste forms. The TRUWIP investigated and tested various types of sintered ceramic waste forms for TRU ashes and blended wastes. In the AWFP, a study was made that compared several alternative ceramic waste forms to a glass. The properties of a recrystallized basalt glass ceramic were also investigated in this program.

TRU Waste Forms

A scoping study was conducted for the TRUWIP to determine if durable sintered ceramic waste forms could be made from TRU wastes blended with selected additives. Two simulated waste compositions characteristic of the Rocky Flats Plant were used. One composition is a blend of Rocky Flats Plant TRU waste (RFP-blend), and the other is a specific alpha-ash (RFPalpha) typical of a fluidized-bed incinerator (Ziegler et al. 1977). The wastes were simulated by mixes of individual chemical compounds.

Four series of samples were studied for each waste composition:

- waste without additives

- waste with glass frit additive ${ }^{(a)}$

- waste with silica additive (-200 mesh)

- waste with clay additive (bentonite). (b)

(a) \#3GF29E (-200 mesh), 0. Hommel Company, Carnegie, PA 15106.

(b) Fisher Scientific Laboratory Grade Powder. 
Use of such additives may enhance the properties of the final waste form by

- increasing sintering by providing a vitreous phase

- increasing consolidation by providing a low-temperature matrix

- producing stable crystalline phases.

The samples used in this study were pellets $(\sim 1.6-\mathrm{cm}$ diameter $\mathrm{x} \sim 1.3-\mathrm{cm}$ long) formed by cold pressing and sintering in an air atmosphere for 2 hours at temperatures of 700 to $1100^{\circ} \mathrm{C}$.

Sintered samples were characterized by measuring bulk density, true density, impact behavior, and leachability. Volatility information was determined from measurements of the weight loss that occurred during sintering, which ranged from 12 to 20 wt $\%$ for alpha ash and 10 to 13 wt \% for blended wastes without additives. With sintering additives weight losses ranged from 1 to $15 \mathrm{wt} \%$ for the alpha-ash samples and 6 to $13 \mathrm{wt} \%$ for the blended waste samples.

Bulk densities of sintered samples ranged from 1.32 to $2.16 \mathrm{~g} / \mathrm{cm}^{3}$ for the blend-additive samples and 1.11 to $2.10 \mathrm{~g} / \mathrm{cm}^{3}$ for the alpha-additive samples. In general, the frit additives produce denser waste forms at 700 and $800^{\circ} \mathrm{C}$. Porosity ranged from 17 to 54 vol\% for the blend-additive samples and 14 to 60 vol\% for the alpha-additive samples. The higher porosity materials were those containing $\mathrm{SiO}_{2}$ and bentonite that were fired at lower temperatures. Samples containing these additives require higher temperatures to increase sintering and reduce porosity.

Impact behavior was determined using a modified punch and die apparatus (Bunnell 1979). A weight was dropped on the punch to obtain a total impact of $158.4 \mathrm{ft}-1 \mathrm{~b}$. Particle size distribution of the impacted samples was determined by sieve analysis. (It should be noted that impact tests on sintered waste forms are difficult to analyze since some of the fractured sample is pressed together or agglomerated by the impact.) The fraction less than 37 um produced by impact ranged from 7 to $17 \mathrm{wt} \%$ for the waste forms containing the blended waste. For those made with alpha ash the respirable fraction ranged from 3 to $23 \mathrm{wt} \%$. Typical values for glass monoliths are around $10 \mathrm{wt} \%$.

Leach resistance was determined by placing 1 gram of -200-mesh powder in $10 \mathrm{ml}$ of deionized water (DIW). The test specimens were held at $90^{\circ} \mathrm{C}$ for 72 hours, followed by filtration and leachate analysis using an induction-coupled plasma emission spectrophotometer (ICP). Figure 1 demonstrates the effects of additives, additive loading, and sintering temperatures for four of the waste elements. These data suggest that additives can significantly improve waste form resistance to leaching and that sintering temperature is important in producing durable crystalline reaction phases. For both wastes those samples containing bentonite at $67 \mathrm{wt} \%$ and sintered at or above $1000^{\circ} \mathrm{C}$ exhibited the best leaching resistance.

This scoping study demonstrated that the properties of typical TRU incinerator ashes and waste blends can be improved using additives to form sintered ceramic waste forms. Leachability appears to be the most influential parameter in selection of a single additive. Volatility, impact resistance, and density of the various additive waste forms fall within a narrow range. Samples with bentonite at the $67 \mathrm{wt} \%$ level and sintered at temperatures of $\geq 1000^{\circ} \mathrm{C}$ offer considerable promise for both alpha ash and blended waste immobilization. 


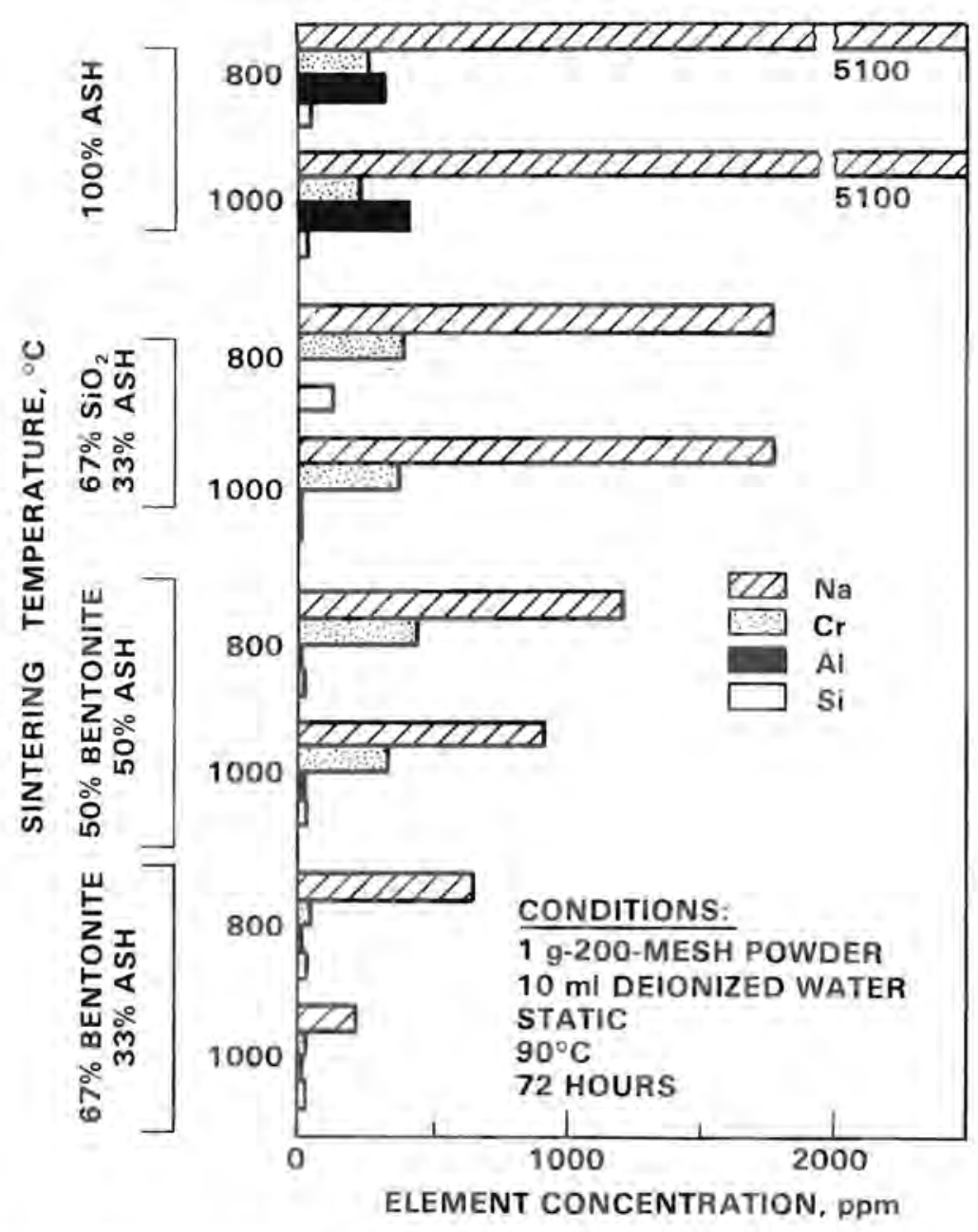

FIGURE 1. Solution Analys is of Leachate from TRU Waste Forms Containing Ash

Waste form samples containing simulated fluidized-bed incinerator ash and additives of silica and bentonite clay were fabricated by cold pressing at $140 \mathrm{MPa}(20,000 \mathrm{psi})$ and sintering for 2 hours at temperatures between 700 and $1100^{\circ} \mathrm{C}$. Leaching behavior was determined at $90^{\circ} \mathrm{C}$ for 72 hours by placing 1 gran of -200 -mesh powder in $10 \mathrm{ml}$ of deionized water. Data for selected samples suggest that additives can significantly improve waste form resistance to leaching. Sintering temperature is important in producing durable crystalline reaction phases. Samples containing bentonite at $67 \mathrm{wt} \%$ and sintered at or above $1000^{\circ} \mathrm{C}$ exhibited the best leaching resistance.

\section{Comparative Study}

Several alternative processes and waste form options exist for the immobilization of nuclear wastes. These options can be categorized into seven groups (Rusin 1978) including the reference monolithic glass process: glass, crystalline ceramics, glass ceramics, hot-pressed ceramics, coatings, concrete, and metal matrix. Although data exist on the characterization 
of these alternatives, it is difficult to conduct product comparisons due to a lack of standard testing procedures. A characterization study utilizing comparative tests was initiated at PNL by the AWFP to assess product inertness of alternative waste forms. A parallel study is also underway to assess process complexity. Final assessment of alternative waste forms will be made by comparing product integrity and process complexity. Specific waste form options were selected that were representative of each basic waste form category. The simulated nuclear waste loading varied from 5 to $100 \%$ depending upon waste form type.

Eight simulated waste forms were prepared for property comparisons. Seven of the waste forms were tailored from a calcined liquid waste that was high in sodium; that is, a PW-9 waste stream (Ross 1978). The glass, PNL composition 76-68, was prepared from a PW-8a waste stream (Ross 1978), which has an even higher sodium and iron content. The five product types investigated were sintered ceramics, glass ceramics, hot-pressed ceramics, concrete, and glass as the reference waste form.

The crystalline ceramic products were cold-pressed cylinders of powder that were subsequently densified by firing in air. Materials included PW-9 calcine, PW-9 calcine plus 50 wt\% glass frit, (a) and SPC-5B supercalcine (MCElroy et al. 1979). In addition, PW-9 calcine pellets were produced by hot pressing. Formulation of glass ceramics was based upon a celsian type (Lutze et al. 1979) and was prepared containing 20 wt\% PW-9 calcine. Two concrete products were produced from Type II Portland cement ${ }^{(b)}$ and either 10 wt\% PW-9 calcine or 10 wt\% crystallized SPC-5B supercalcine. The crystalline phases in the samples as determined by $x$-ray diffraction are identified in Table 1 , as are representative bulk properties.

Three basic tests were performed on all the comparative studies materials to assess product inertness: static leaching, elevated temperature volatility, and mechanical strength through impact and load-to-failure compression tests.

Static leach testing of alternative waste forms was performed to evaluate the effects of time, temperature, solution, sample surface area, and volume of leach solution on leach behavior. Ion concentrations in solution were measured by the ICP technique. Leach testing covered a time-temperature span of 1 to 9 days between 30 and $200^{\circ} \mathrm{C}$ at a surface area-tosolution volume ratio (SA/SV) range of 0.6 to $60 \mathrm{~m}^{-1}$. The principal leachant was deionized water; however, salt brine and an acid buffer solution were also used on a limited basis.

To provide a unit of leachability that is valid for comparison of waste forms with differing compositions, the detected elemental analyses from the leachates have been normalized to the bulk compositions of the waste forms using the following equation:

$$
\begin{aligned}
& \text { leachability of } \\
& \text { element } x \text { from } \\
& \text { waste form }
\end{aligned}\left(\text { normalized } \frac{\mathrm{g}}{\mathrm{m}^{2}}\right)=\frac{\text { [mass of element } x \text { in solution] }(\mathrm{g})}{\left[\begin{array}{c}
\text { mass fraction } \\
\text { of element } x \text { in } \\
\text { waste form }
\end{array}\right] \text { (unitless) }\left[\begin{array}{c}
\text { geometric surface } \\
\text { surface area of } \\
\text { sample }
\end{array}\right]\left(\mathrm{m}^{2}\right)}
$$

This unit is employed wherever possible throughout the report.

(a) 0. Hommel Co., code OHCO 3GF29E

(b) Lehigh Portland Cement Co., Type I I, ASTM C-150 
TABLE 1. Bulk Density and Crystalline Phases Present in Waste Form Samples Used in Comparative Study

\begin{tabular}{|c|c|c|c|}
\hline WASTE FORM & $\begin{array}{c}\text { WASTE } \\
\text { LOADING } \\
\text { wt } \%\end{array}$ & $\begin{array}{c}\text { BULK } \\
\text { DENSITY, } \\
\mathbf{g} / \mathbf{c m}^{3}\end{array}$ & $\begin{array}{c}\text { PRINCIPAL CRYSTALLINE } \\
\text { PHASES }\end{array}$ \\
\hline SINTERED PW-9 & 100 & 3.55 & $\begin{array}{c}\mathrm{CeO}_{2} \\
\left(\mathrm{Zr}, \mathrm{Ce}_{\ldots} \ldots \mathrm{O}_{2}\right. \\
\mathrm{RuO}_{2}\end{array}$ \\
\hline $\begin{array}{l}\text { SUPERCALCINE } \\
\text { SPC-5B }\end{array}$ & 50 & 2.4 & $\begin{array}{c}(\mathrm{Ca}, \mathrm{Sr}, \mathrm{Ba})_{2}(\mathrm{NaAlSiO})_{5}\left(\mathrm{MoO}_{4}\right)_{2} \\
(\mathrm{Na}, \mathrm{K}) \mathrm{AlSiO} \mathrm{SiO}_{4} \\
(\mathrm{Cs}, \mathrm{Na}) \mathrm{AlSi}_{2} \mathrm{O}_{6} \\
\mathrm{RuO}_{2} \\
\mathrm{Ca}_{2}(\mathrm{RE})_{8}\left(\mathrm{SiO}_{4}\right)_{6} \mathrm{O}_{2}\end{array}$ \\
\hline $\begin{array}{l}\text { SINTERED } \\
\text { GLASS FRIT } \\
+50 \% \text { PW-9 }\end{array}$ & 50 & 2.21 & $\begin{array}{l}\mathrm{BaMoO}_{4} \\
\mathrm{PuO}_{2}\end{array}$ \\
\hline GLASS 76-68 & 33 & 3.0 & $\begin{array}{l}\mathrm{PuO}_{2} \\
\mathrm{Pd}\end{array}$ \\
\hline $\begin{array}{l}\text { CELSIAN } \\
\text { GLASS } \\
\text { CERAMIC }\end{array}$ & 20 & 3.1 & $\begin{array}{c}\mathrm{BaAl}_{2} \mathrm{Si}_{2} \mathrm{O}_{8} \\
\mathrm{BaMOO}_{4} \\
\mathrm{RE}_{2} \mathrm{Ti}_{2} \mathrm{O}_{7}\end{array}$ \\
\hline $\begin{array}{l}\text { CEMENT } \\
+ \text { PW-9 } \\
+ \text { SPC-5B }\end{array}$ & $\begin{array}{r}10 \\
5\end{array}$ & $\begin{array}{l}1.71 \\
1.85\end{array}$ & $\begin{array}{l}\mathrm{Ca}(\mathrm{OH})_{2} \\
\mathrm{Ca}_{3} \mathrm{SiO}_{5}\end{array}$ \\
\hline
\end{tabular}

Bulk densities and crystalline phases present in the comparative study samples are shown. High bulk density and waste loading are advantageous in a waste form since they will reduce the volume of the product that must be transported to and stored in a repository. As is shown, a number of crystalline phases may be present. Some, such as $\mathrm{Ce}_{2}$, are chemically durable; others, such as $\mathrm{Na}_{2} \mathrm{MoO}_{4}$, are not. Glass 76-68 is primarily vitreous; however, small amounts of $\mathrm{RuO}_{2}$ and $P d$ are present as discrete crystalline phases.

Leach data for five of the materials studied are given for $90^{\circ} \mathrm{C}$ for 9 days (SA/SV $=60 \mathrm{~m}^{-1}$ ) and $200^{\circ} \mathrm{C}$ for 3 days $\left(S A / S V=60 \mathrm{~m}^{-1}\right.$ ) in Table 2 . It can be seen that the sintered calcine waste form does not successfully retain any of the elements of concern. In fact, after these periods of time and temperature, the sintered calcine waste form had completely broken apart. When the same waste calcine was added to a matrix former such as cement or a glass-forming frit, the leach resistance improved significantly. Retention of sodium and cesium are still quite low with the cement matrix. When waste ions are incorporated in a crystalline or glassy matrix such as supercalcine or glass, another increase in leach resistance is noted. Glass and supercalcine show similar trends under both hydrous and hydrothermal conditions with glass exhibiting a greater retention of sodium and molybdenum, supercalcine having a greater retention of cesium, and both forms being approximately equal in strontium retention. As found in other high-temperature tests (as shown in Figure 23 p. 49) elemental leach rates of glass and supercalcine are not very different.

Initial volatility evaluations on all comparative studies materials were conducted at elevated temperatures typical of previous work (Rusin et al. 1979) and were performed on 
TABLE 2. Leaching Behavior of Comparative Study Waste Forms

\section{ELEMENTAL LOSS, normalized $\mathrm{g} / \mathrm{m}^{2}$}

\begin{tabular}{|c|c|c|c|c|c|}
\hline ELEMENT & SINTERED PW-9 & $\begin{array}{l}\text { CEMENT + } \\
10 \% \text { PW-9 } \\
\end{array}$ & $\begin{array}{l}\text { SINTERED } \\
\text { GLASS FRIT } \\
+50 \% \text { PW } 9 \\
\end{array}$ & $\begin{array}{c}\text { SUPERCALCINE } \\
\text { SPC-5B } \\
\end{array}$ & GLASS 76.68 \\
\hline $\mathbf{N a}$ & 6800 & 2370 & 91 & 33 & 25 \\
\hline Si & N.A. & 0.4 & 9 & 4 & 6 \\
\hline $\mathrm{Sr}_{\mathbf{r}}$ & $<0.7$ & 91 & 2 & $<0.4$ & $<0.6$ \\
\hline Mo & 6800 & 30 & $\mathbf{7 4}$ & 33 & 25 \\
\hline Cs & $\mathbf{3 8 0 0}$ & 1800 & 4 & 0.4 & 6 \\
\hline
\end{tabular}

$200^{\circ} \mathrm{C}, 3$ DAYS, SA $/ \mathrm{SV}=60 \mathrm{~m}{ }^{1}$

\section{SINTERED}

CEMENT + GLASS FRIT SUPERCALCINE

\begin{tabular}{|c|c|c|c|c|c|}
\hline ELEMENT & SINTERED PW-9 & $10 \%$ PW-9 & $+50 \%$ PW-9 & SPC-5B & GLASS 76-68 \\
\hline $\mathbf{N a}$ & 4700 & 1360 & 47 & 100 & 51 \\
\hline Si & N.A. & 0.5 & 10 & 3 & 23 \\
\hline $\mathrm{Sr}$ & $<0.5$ & 20 & $<0.3$ & 1 & $<0.2$ \\
\hline Mo & 4700 & 20 & 30 & 250 & 55 \\
\hline Cs & 1.4 & 8 & 0.6 & 0.9 & 12 \\
\hline
\end{tabular}

Leach resistance is one of the most important factors in waste form evaluation. Static leach tests were performed on five waste forms in deionized water at 90 and $200^{\circ} \mathrm{C}$. The data indicate that the sintered calcine waste form $\mathrm{PW}-9$ does not retain $\mathrm{Na}$, Mo, and $\mathrm{Cs}$ when leached at $90^{\circ} \mathrm{C}$. It, in fact, does not remain a solid.

When the same waste calcine is added to a matrix former such as cement or a glassforming frit, the leach resistance improves significantly. Retention of Na and Cs, however, is still quite low with the cement matrix. Glass and supercalcine are similar under both temperature conditions; however, glass exhibits a greater retention of $\mathrm{Na}$ and Mo, supercalcine has a greater retention of $\mathrm{Cs}$, and both forms are approximately equal in $\mathrm{Sr}$ retention.

The apparent fact that the sintered $\mathrm{PW}-9$ calcine and cement waste forms have fewer ions in solution at $200^{\circ} \mathrm{C}$ than at $90^{\circ} \mathrm{C}$ may be due to either precipitation of crystalline phases or plate-out on to the autoclave walls. This effect would be a function of solubility and thus was probably not observed for the more durable supercalcine and glass waste forms due to fewer ions in solution.

right circular solid cores with a geometric surface area of $472 \mathrm{~mm}^{2}$. Four temperatures were chosen for the test: $700,900,1100$, and $1300^{\circ} \mathrm{C}$, with a hold time at temperature of 3 hours. Volatility was measured on all samples by determining the weight change before and after heating.

Volatility measurements for four materials are illustrated in Figure 2, and sintered PW-9 calcine is seen to be the poorest performer. As in the other tests, it would seem to follow that without a host matrix former mechanical agglomeration of particles is not adequate to keep dispersion (volatility) down. An order of magnitude decrease in volatility is realized when the waste stream is tied to a crystalline host, as in the case of supercalcine. The volatile losses in the glass, supercalcine, and glass ceramic waste forms are about two orders of magnitude lower than sintered PW-9 calcine at the lower temperature 


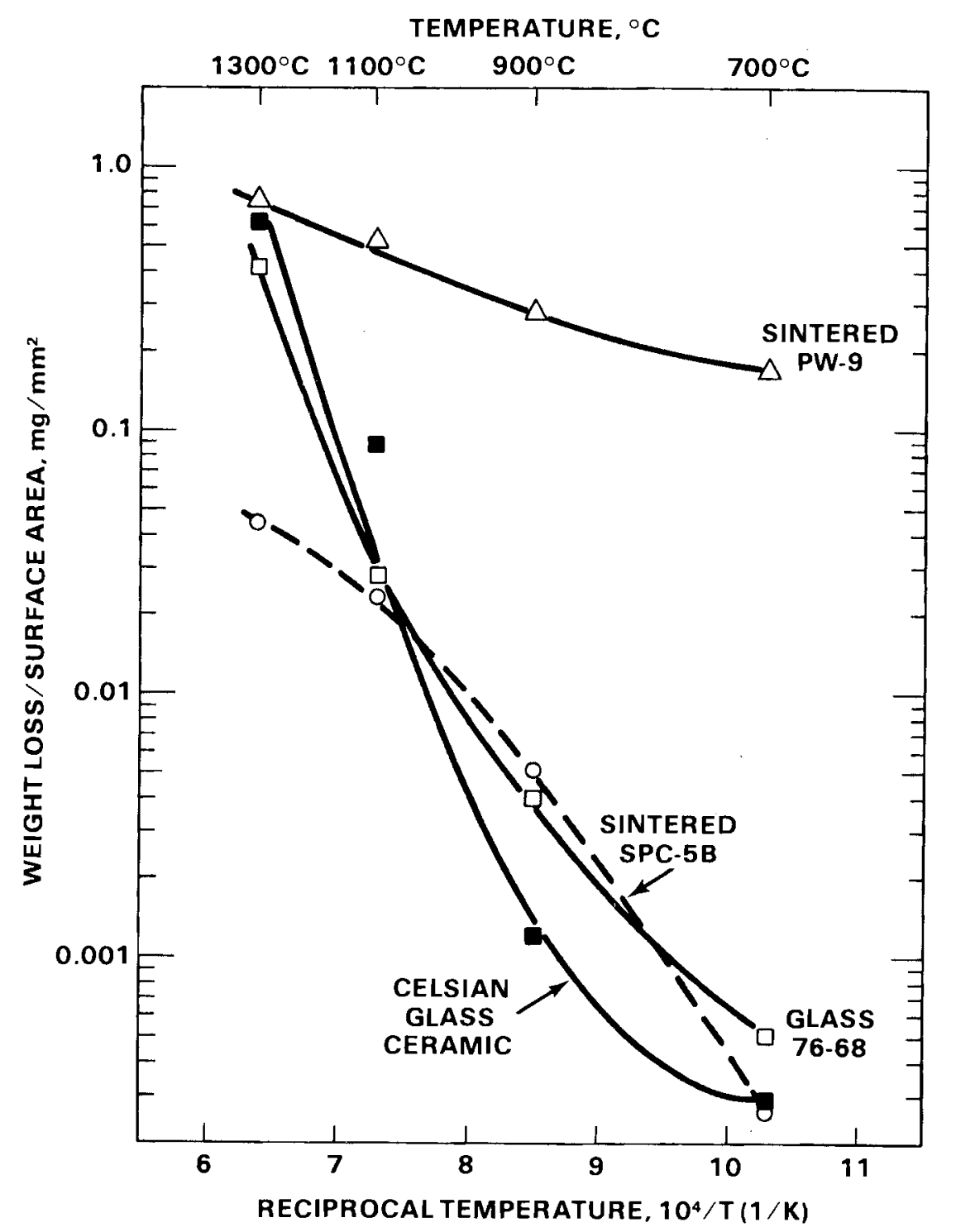

FIGURE 2. Volatility Measurements for Selected Comparative Study Samples

Volatility is an important process parameter and a factor in risk analysis. Volatile loss was measured by determining the weight loss after heating at selected temperatures for 3 hours. The test indicated that sintered PW-9 calcine was the poorest performer, with the largest weight loss at all temperatures. As in the other tests, it would seem to follow that without a host matrix former mechanical agglomeration of particles is not adequate to reduce volatility. The curves indicate that when the waste calcine is incorporated in a crystalline or glassy host an order of magnitude decrease in volatility occurs.

By comparing the crystalline host form--supercalcine--to the glassy host form--76-68 glass--it is evident that the glass has comparatively lower volatility at low temperatures $\left(700-900^{\circ} \mathrm{C}\right)$ and the supercalcine has lower volatility at high temperatures $\left(1100-1300^{\circ} \mathrm{C}\right)$. As the glass reaches a low viscosity state (approximately $1050^{\circ} \mathrm{C}$ ) its volatility increases probably because the depleted surface can be replenished with fresh volatile components by the action of convection currents. The celsian glass ceramic behaves similarly to glass 76-68, especially in the higher temperature range where it too becomes molten. 
regime $\left(700-900^{\circ} \mathrm{C}\right)$; however, for the glass and glass ceramic they increase to nearly the same values at the upper temperature regime $\left(1100-1300^{\circ} \mathrm{C}\right)$. This indicates that as the glass-containing forms approach or exceed their melting points volatile losses increase significantly.

Volatile measurements for glass 76-68 closely agree with previous work (Gray 1980); however, volatile losses for the supercalc ine SPC-5B waste form are higher than for previous supercalcine types. These higher losses may be attributed to higher sodium concentration in this supercalcine type since sodium has been found to be a volatile species in the supercalcine system.

To compare the mechanical strength of the wide range of glass and ceramic waste forms examined in this study requires a test that can be applied meaningfully throughout. Compressive strength test results are illustrated in Figure 3. Although the diametral compression test does not assess impact-type $r$ isk analys is questions, it does give a meaningful measure of comparative mechanical strength since it is applicable to the entire range of materials studied. Deviations were found to be approximately $+10 \%$.

Sintered PW-9 and cement matrix materials have the lowest strength values of the materials measured; however, by applying hot pressing or adding $50 \%$ of a glass-forming frit to the calcine, average strength values can be increased by about $60 \%$. This apparently results from an enhanced mechanical bonding realized by increased particle agglomeration. The supercalcine waste form shows an increase in average strength of $\sim 120 \%$ over the next lowest material. In this case, the increase is due to increased physical bonding resulting from the ingrowth of crystalline phases and the interaction with an amorphous phase. This represents an improvement over the simple mechanical bonding of discrete particles in cement or simple calcine systems. The glass and glass ceramic waste forms represent matrices containing fewer defects than the ceramic materials with the continuum or vitreous material providing the main basis of the strength.

In summary, it was found that supercalcine, glass, and glass ceramic waste forms had similar characteristics and can be grouped together as highly durable waste forms. The sintered PW-9 calcine and concrete waste forms have low durability. Hot pressing or the addition of a frit to the $\mathrm{PW}-9$ calcine produces improved intermediate durability waste forms.

Basalt Glass Ceramics

Basalt glass and basalt glass ceramics are being studied as potential waste forms by the AWFP. Basalt can be melted at temperatures from 1200 to $1400^{\circ} \mathrm{C}$ to form a black vitreous material and then can be recrystallized into a fine-grained glass ceramic (Beall and Ritter 1976). Basalt-based waste forms containing 20 wt\% waste oxides have advantages over other waste forms in that the material would be in close chemical equilibrium with a basalt repository. Additionally, since glass ceramics have undergone thermal treatments at temperatures ranging from 800 to $950^{\circ} \mathrm{C}$, their structures are relatively resistant to further alteration. 
AVERAGE STRENGTH, $\times 1000 \mathrm{psi}$

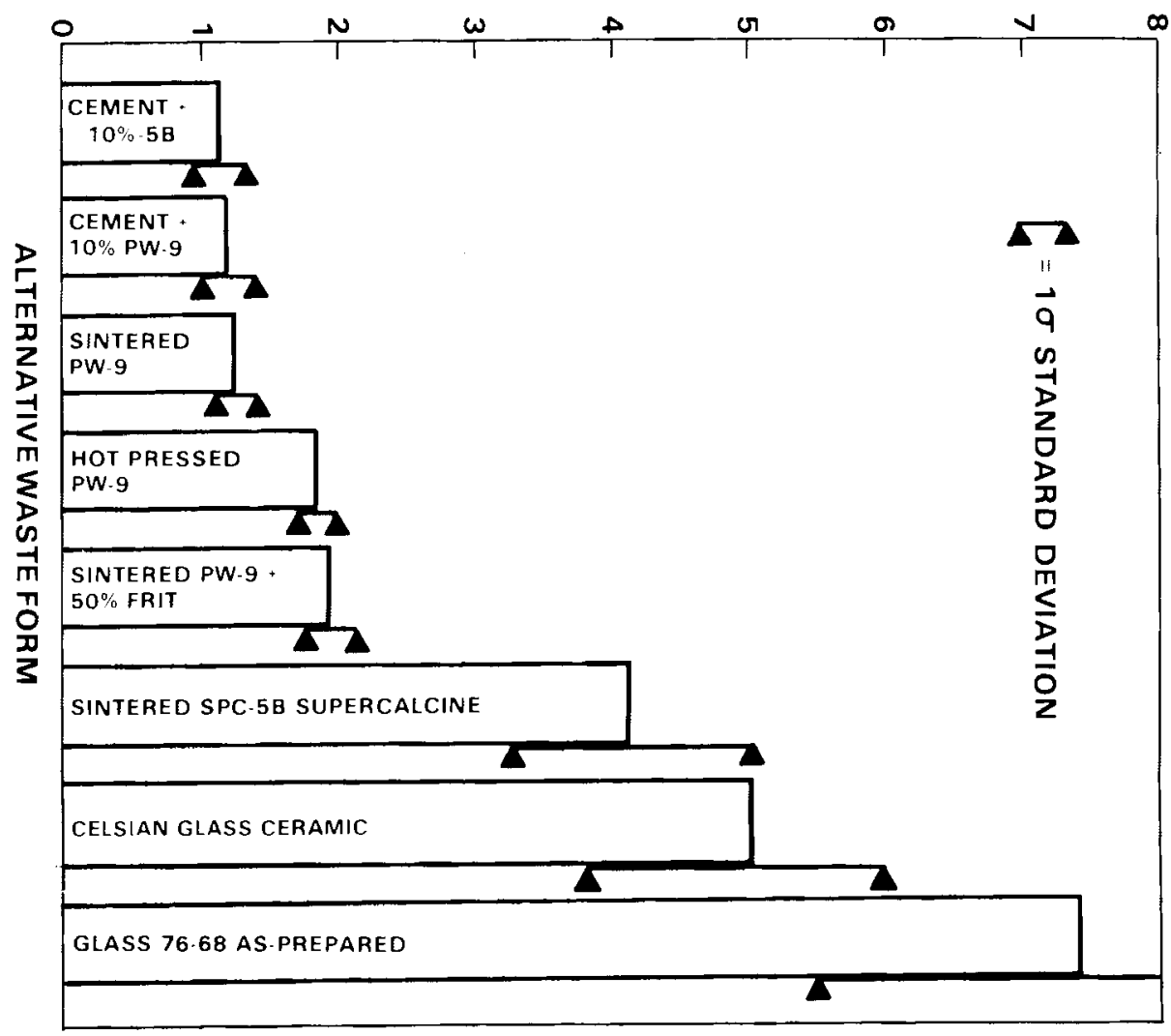

FIGURE 3. Compressive Strength of Comparative Study Samples

The compressive strength of a waste form is an important factor in risk analysis (for example, in assessing the consequences of a transportation accident). Although the diametral compression test does not directly address impact-type risk analys is questions, it does give a meaningful measure of comparative mechanical strength since it is applicable to the entire range of materials studied. Glass 76-68, celsian glass ceramic, and supercalcine SPC-5B have high compressive strengths when compared to sintered PW-9 and cement products. This is apparently due to a stronger continuum bond resulting from a glassy matrix or crystalline ingrowth over a simple mechanical agglomeration of particles.

Basalt-based waste forms were produced by melting Pamona basalt with 20 wt\% PW-9 calcine at $1400^{\circ} \mathrm{C}$ and heat treating for 4 hours at $670^{\circ} \mathrm{C}$ and for 8 hours at $920^{\circ} \mathrm{C}$. Static leach tests in deionized water were conducted on both glass and glass ceramic samples to determine how recrystallization affected chemical durability. The samples were leached for 9 days at 90 or $150^{\circ} \mathrm{C}$.

The results indicate that recrystallization increased leach resistance. The amount of individual species leached from the glass ceramic was less than from the vitreous material, 
and the major crystalline phase produced during heat treatment was a calcium magnesium silicate or augite. The amounts of calcium and magnesium leached from the glass ceramic at $90^{\circ} \mathrm{C}$ were $0.60 \mathrm{~g} / \mathrm{m}^{2}$ (normalized) and $0.22 \mathrm{~g} / \mathrm{m}^{2}$, respectively; and the amounts of calcium and magnesium leached from the basalt glass were $2.48 \mathrm{~g} / \mathrm{m}^{2}$ and $2.00 \mathrm{~g} / \mathrm{m}^{2}$, respectively. This suggests that the formation of augite crystals results in a material that is more resistant to loss of calcium and magnesium than is the basalt glass (see Figure 4). Other materials in the waste form showed similar decreases in leachability after recrystallization.

Coated Particle Development

One method of assuring that nuclear wastes are isolated from the environment is to have successive barriers in place that limit radionuclide release. Adding inert coatings to waste-bearing particles is one possible means for accomplishing this.

Three areas have been investigated in coated particle work. The ability of pyrolytic carbon (PyC) coatings or dual layer coatings of carbon and $\mathrm{Al}_{2} \mathrm{O}_{3}$ to 1 imit waste leaching was tested as part of the AWFP. In another portion of this program, PyC coatings deposited by a low-temperature process were evaluated. Finally, the reaction of graphite with water was tested in an effort to understand the mechanisms and rates of reaction of carbon coatings in an aqueous environment.

\section{Leach Resistance of Coated Supercalcine Spheres}

One of the objectives of the AWFP is to develop coated particle waste forms that become part of the multibarrier concept upon encapsulation. The goal of the present leach resistance study is to assess the effectiveness of $\mathrm{PyC}$ and $\mathrm{Al}_{2} \mathrm{O}_{3}$ coatings in immobilizing simulated fission products in supercalcine cores.

Supercalcine is a crystalline assemblage of solid solution phases made by modifying the composition of high-level liquid waste ( $\mathrm{HLLW}$ ) with selected additives (primarily $\mathrm{SiO}_{2}, \mathrm{CaO}$, and $\mathrm{Al}_{2} \mathrm{O}_{3}$ ) prior to calcining. Two formulations, SPC-2 and SPC-4, were studied. Spherical pellets ( 1-2 $\mathrm{mm}$ in diameter) were formed by disc pelletization and subsequently sintered in air between 1100 and $1200^{\circ} \mathrm{C}$ for consolidation and crystal development.

Chemical vapor deposition (CVD) was selected as a feasible method of coating ceramic cores because the technology had been demonstrated for high-temperature gas-cooled reactor (HTGR) fuel particles. Coatings were applied to the 1- to 2-mm particles using either fluidized or vibrating beds.

The coatings were evaluated by metallographic and scanning electron microscope (SEM) examination and by leach resistance. Five types of spheres were studied: Two were uncoated SPC-2 and SPC-4; one was SPC-2 coated with PyC; one was SPC-4 coated with $\mathrm{Al}_{2} \mathrm{O}_{3}$; and the last was SPC-2 with an inner PyC and an outer $\mathrm{Al}_{2} \mathrm{O}_{3}$ coating. The geometric surface areas of these spheres ranged from 0.08 to $0.16 \mathrm{~cm}^{2}$. The spheres were leached in deionized water and in a $0.5-\mathrm{M} \mathrm{NaCl}$ solution for 14 and 28 days at 50,90 , and $150^{\circ} \mathrm{C}$ with an SA/SV of $10 \mathrm{~m}^{-1}$.

Leach data for selected elements are shown in Table 3. Examination of these results suggests that the duplex $\mathrm{PyC}_{-} \mathrm{Al}_{2} \mathrm{O}_{3}$ coating is superior; however, this conclusion may be misleading because duplex coatings are somewhat thicker than single coatings. Comparison of 

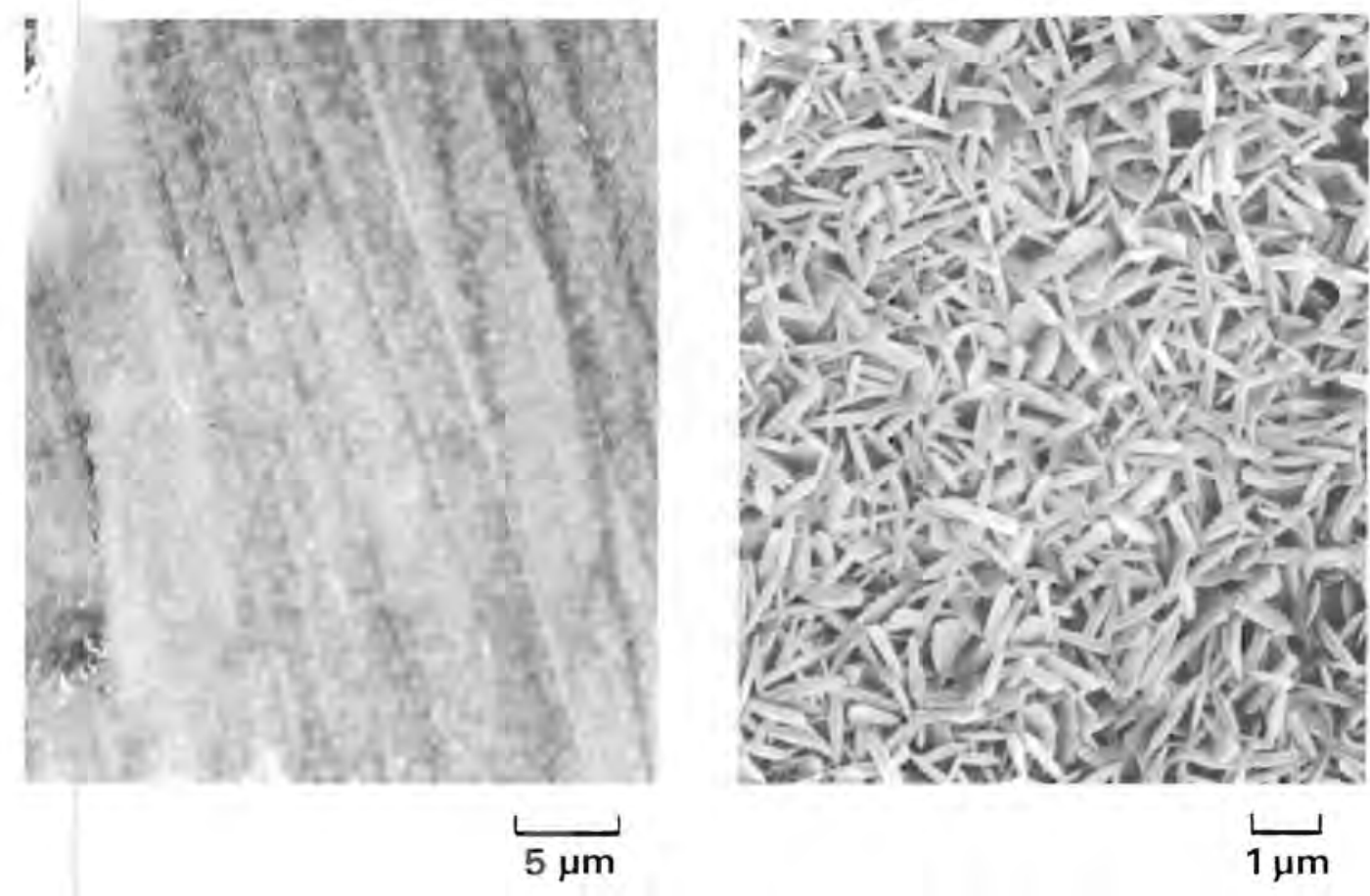

FIGURE 4. Effect of Leaching on the Surface of a Basalt Glass Ceramic

A basalt glass ceramic waste form was prepared by mixing 20 wt\% PW-9 calcine (simulated power reactor waste) with basalt, melting, and recrystallizing for 12 hours (4 hours at $670^{\circ} \mathrm{C}$ and 8 hours at $920^{\circ} \mathrm{C}$ ). A two-phase microstructure is evident in the prepared sample surface with lines caused by 600-grit polishing. After leaching for 9 days at $150^{\circ} \mathrm{C}$ in deionized water, the glassy matrix was dissolved. The remaining crystals are platelets slightly smaller than 1 micron with an approximate composition of $\mathrm{CaMgSi}_{2} \mathrm{O}_{6}$.

the PyC with the $\mathrm{Al}_{2} \mathrm{O}_{3}$ coating in the $90^{\circ} \mathrm{C}$ leach tests suggests that the $\mathrm{Al}_{2} \mathrm{O}_{3}$ coating is generally more effective, particularly in containing the more mobile elements such as Cs and $\mathrm{Na}$. Moreover, a single $\mathrm{Al}_{2} \mathrm{O}_{3}$ coating is about as effective as the duplex $\mathrm{PyC}$ and $\mathrm{Al}_{2} \mathrm{O}_{3}$ coatings. Leach tests at $150^{\circ} \mathrm{C}$, however, indicate that both $\mathrm{PyC}$ and $\mathrm{Al}_{2} \mathrm{O}_{3}$ coatings were almost equally effective although PyC was possibly a little better. The $150^{\circ} \mathrm{C}$ tests were conducted with a separate batch of PyC-coated spheres that yielded Cs leach results comparable with the $\mathrm{Al}_{2} \mathrm{O}_{3}$ and duplex coatings. SEM examination of PyC-coated spheres used in the $90^{\circ} \mathrm{C}$ tests indicated a CS buildup in the coating that probably resulted from processing conditions. Consequently, the effects of processing conditions leading to more durable coatings are currently being investigated.

There appears to be an advantage to using lower temperatures in applying PyC coatings due to a decrease in Cs volatility from the supercalcine cores. The ability to coat glass marbles is an additional incentive to the development of low-temperature coating processes since glass softens at $\sim 600^{\circ} \mathrm{C}$ and would be molten at typical coating temperatures of 1100 to $1200^{\circ} \mathrm{C}$. 
TABLE 3. Leaching Behavior of Coated Supercalcine Multibarrier Waste Forms LEACHING CONDITIONS

$90^{\circ} \mathrm{C}$ - 28 DAYS

$\mathrm{SA} / \mathrm{SV}=10 \mathrm{~m}^{-1}$

ELEMENT LEACHED $\mathbf{g} / \mathbf{m}^{2 *}$

\begin{tabular}{|c|c|c|c|c|c|c|c|c|c|}
\hline \multirow[b]{2}{*}{ CORE } & \multirow[b]{2}{*}{ COATING } & \multirow[b]{2}{*}{ Si } & \multicolumn{3}{|c|}{$\begin{array}{c}\text { IN DEIONIZED } \\
\text { WATER }\end{array}$} & \multicolumn{4}{|c|}{ IN $0.5-\mathrm{M} \mathrm{NaCl}$} \\
\hline & & & $\mathrm{Ba}+\mathrm{Ca}$ & Sr & $\mathrm{Cs}$ & $\mathrm{Si}$ & $\mathrm{Ba}+\mathrm{Ca}$ & $\overline{S i}$ & Cs \\
\hline SPC-2 & NONE & 0.59 & 0.52 & 0.22 & 0.112 & 0.60 & 0.77 & 0.27 & 0.032 \\
\hline SPC-2 & PyC & 0.004 & 0.017 & 0.01 & 0.14 & 0.014 & 0.071 & 0.011 & 0.068 \\
\hline SPC-4 & NONE & 0.46 & 0.16 & 0.12 & 0.19 & 0.42 & 0.44 & 0.20 & 0.045 \\
\hline SPC-4 & $\mathrm{Al}_{2} \mathrm{O}_{3}$ & 0.007 & 0.01 & $<0.001$ & 0.011 & 0.014 & 0.051 & 0.001 & 0.012 \\
\hline SPC-4 & $\mathrm{PyC} / \mathrm{Al}_{2} \mathrm{O}_{3}$ & 0.007 & 0.01 & $<0.001$ & $<0.005$ & 0.13 & 0.061 & 0.003 & 0.011 \\
\hline
\end{tabular}

* LEACH UNITS NOT NORMALIZED BY DIVIDING BY ELEMENT WEIGHT FRACTION IN WASTE FORM.

Coatings of carbon and/or alumina may reduce the leach rates of multibarrier waste forms. Waste form pellets that were coated in this experiment were supercalcine crystalline phase assemblages ( $\sim 2 \mathrm{~mm}$ in diameter) formed by disc pelletizing and sintering between 100 and $1200^{\circ} \mathrm{C}$. Ten-micron coatings of pyrolytic carbon (PyC), alumina, or duplex coatings of $\mathrm{PyC}$ (inner) and $\mathrm{Al}_{2} \mathrm{O}_{3}$ (outer) were applied by either fluidized or vibrating bed processes. Leach results indicate that the duplex coatings are most effective in improving leach resistance but that single coatings of PyC or alumina are nearly as effective. The $\mathrm{CS}$ release indicated in the $90^{\circ} \mathrm{C}$ PyC leach results was probably due to high-temperature carbon deposition. At the $1100-1200^{\circ} \mathrm{C}$ deposition temperature, Cs diffused into the PyC coating. Development of a lower temperature PyC deposition process (see Figure 5, p. 15) may alleviate this problem.

Studies at Battelle Columbus Laboratories have demonstrated that dense carbon coatings can be deposited at temperatures in the range of 325 to $525^{\circ} \mathrm{C}$ using nickel tetracarbonyl, $\mathrm{Ni}(\mathrm{CO})_{4}$, as a catalyst. The $16-\mu \mathrm{m}$ carbon coating shown in Figure 5 was deposited at $425^{\circ} \mathrm{C}$. Leach testing and efforts to increase the coating rate are now underway.

Reaction of Graphite with Water

To verify the high leach resistance of carbon coatings, leach (oxidation) tests were conducted at 200 to $300^{\circ} \mathrm{C}$ in an autoclave using deionized water and powdered graphite. Gas from the vessel was analyzed for $\mathrm{CO}_{2}$ and other gases using a gas chromatograph. Details of the experiment are published elsewhere (Gray 1980).

Figure 6 shows reaction rates of graphite in water and air-oxidation results obtained on samples from the same batch of powdered graphite. Results are not shown for temperatures lower than $200^{\circ} \mathrm{C}$ because so little $\mathrm{CO}_{2}$ was generated that none above that in air $(\sim 0.03 \%)$ was detected. The reaction rate of graphite in water is shown to be much higher than in air, which is thought to be because the reaction in water is with dissolved oxygen rather than with the water itself (Gray 1980). It is also apparent that the reaction in water is catalyzed because the reaction rate in water is higher and the apparent activation energy is lower than for the same graphite in air. 


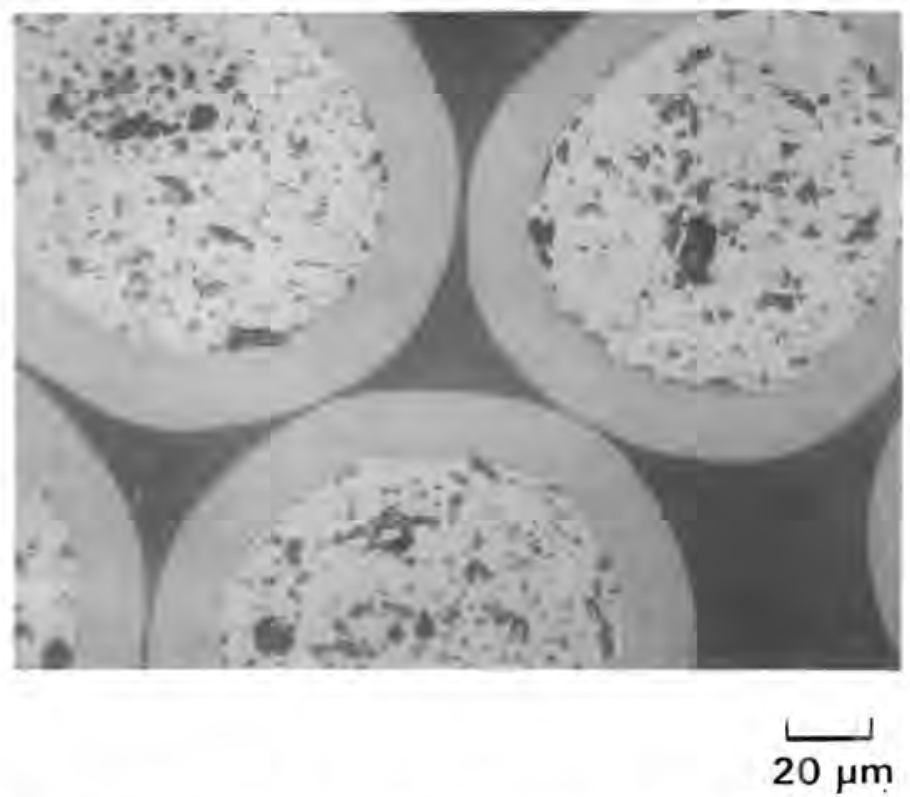

FIGURE 5. Low-Temperature PyC CVD Coating on Simulated Nuclear Waste Pellets

Graphite has the potential to provide a highly resistant leach barrier for nuclear waste forms. Typical processing temperatures for CVO PyC coatings range from 900 to $1500^{\circ} \mathrm{C}$. Process complexity and product volatility increase with temperature; thus, it is important to lower coating temperatures. The micrograph illustrates the type of dense PyC coating that can be achieved using nickel as a catalyst to lower deposition temperature. The coating was applied at $425^{\circ} \mathrm{C}$ using a mixture of $\mathrm{C}_{2} \mathrm{H}_{2}, \mathrm{H}_{2}$, and $\mathrm{Ni}(\mathrm{CO})_{4}$. The deposition rate was $\sim 4 \mu \mathrm{m} / \mathrm{h}$, and the total thickness was $\sim 16 \mu \mathrm{m}$.

Leach tests were also conducted at 250 and $300^{\circ} \mathrm{C}$ using graphite pellets with surface areas much smaller than the powdered material. No additional $\mathrm{CO}_{2}$ concentration above that in air was found, which indicates that it is legitimate to divide the amount of $\mathrm{CO}_{2}$ generated by the large surface area of the powdered graphite and thus obtain a low leach (oxidation) rate per unit area.

Table 4 lists leach rates of two potential waste forms and six other materials for comparison with data presented here. Although different methods were used to determine the leach rates, order-of-magnitude comparisons are appropriate. Thus, graphite is shown to be 4 to 5 orders of magnitude more durable than the best other material listed.

Unlike these experimental conditions where oxygen was readily available, there will be little or no air in sealed waste repositories and even the ground water is likely to be relatively oxygen-free. Thus, data shown in Figure 6 represent a worst case in the sense that the oxidation rate by water in an oxygen-free system would be much lower. However, at least three other factors could change oxidation rates: 


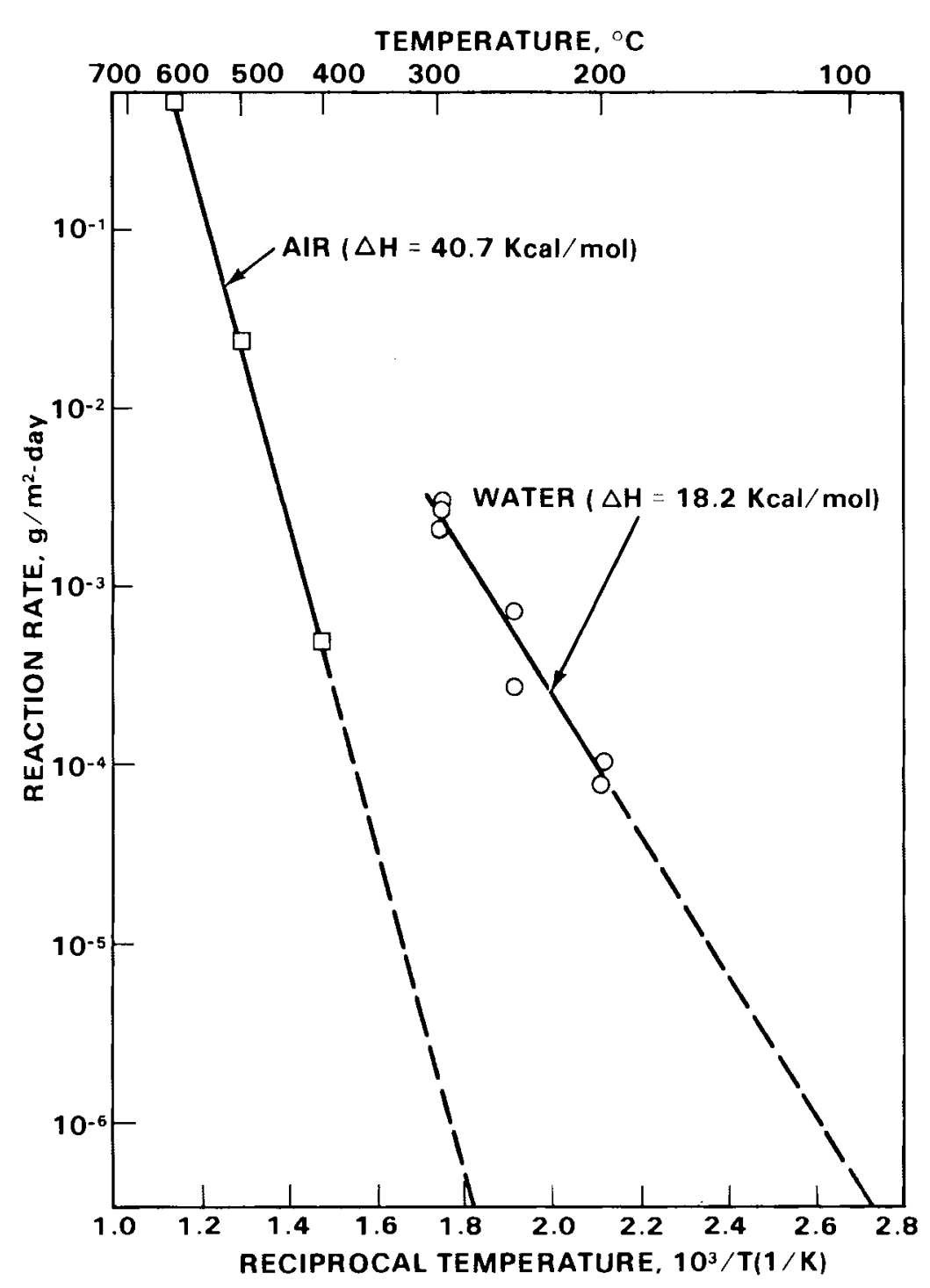

FIGURE 6. Chemical Durability of Graphite

Tests were conducted to investigate the reaction rate of powdered graphite in air and water. In water the reaction is with oxygen rather than with the water itself; therefore, it must be catalyzed because the rate is higher than in air and has a lower activation energy. Although it has not yet been measured, the reaction of graphite with oxygen-free water must necessarily be lower. 
TABLE 4. Comparison of Leach Rates

\begin{tabular}{|l|c|c|}
\hline \multirow{2}{*}{ MATERIAL } & \multicolumn{2}{|c|}{ LEACH RATE $\left(\mathrm{g} / \mathrm{m}^{2-} \mathrm{day}\right)$} \\
\cline { 2 - 3 } & $250^{\circ} \mathrm{C}$ & $99^{\circ} \mathrm{C}$ \\
\hline SUPERCALCINE & $20(\mathrm{a})$ & $1(\mathrm{a})$ \\
$\mathrm{Al}_{2} \mathrm{O}_{3}$ & $80(\mathrm{~b})$ & $4(\mathrm{~b})$ \\
$\mathrm{ZrO}_{2}$ & $1(\mathrm{c})$ & $1 \times 10^{-2}(\mathrm{~d})$ \\
$\mathrm{MULLITE}^{*}$ & $3(\mathrm{c})$ & \\
FUSED SILICA & $10(\mathrm{c})$ & \\
SODA-LIME-SILICA GLASS & $7(\mathrm{c})$ & \\
GRANITE & & $5 \times 10^{-1}$ (d) \\
GRAPHITE & & $1 \times 10^{-1}(\mathrm{~d})$ \\
\hline
\end{tabular}

(a) THREE-DAY TEST IN STATIC WATER. WEIGHT LOSS ESTIMATED FROM SOLUTION ANALYSIS.

(b) TWO-DAY TEST IN STATIC WATER.

(c) SEVEN-DAY TEST IN FLOWING WATER.

(d) THREE-DAY SOXHLET TEST.

(e) ONE-DAY TEST IN STATIC WATER. (THIS WORK.)

(f) EXTRAPOLATED RESULTS FROM ONE-DAY TEST IN STATIC WATER. (THIS WORK.)

Several materials (including graphite) were leach tested under a variety of conditions. Resulting leach rates in deionized water at 250 and $99^{\circ} \mathrm{C}$ indicate that graphite reacts much more slowly than do the other materials tested and, thus, is a promising material for protective coatings on multibarrier waste forms.

- type of graphite - Different carbons and graphites could oxidize at different rates.

- catalytic effects - It was argued that the reaction measured was catalyzed, but the catalyst was not identified. Water containing minerals from potential repositories must be tested to be sure even greater catalytic effects are not encountered.

- radiation field - Gamma radiation is known to raise reaction rates; therefore, this area needs further study (including tests in oxygen-free systems). 
Graphite clearly exhibits a much lower leach rate than any other material examined and should be considered for engineered barriers in a waste management system. Further details of this work may be found in Gray (1980).

\section{GLASS WASTE FORMS}

Glasses continue to show promise as waste form candidates since they are relatively inert and can accept wide waste composition variations while maintaining acceptable processing and product properties. Previous annual reports detail the properties of interest and their desired values.

Glass development has concentrated in two areas. The major portion of work has been on a study of waste glasses to determine the effects that a number of glass oxides have on important glass properties; at present 11 components are being tested. A second focus of glass development has been on vitrification of TRU-contaminated wastes.

Glass Composition Study

The chemical complexity and variability of nuclear waste make it necessary to predict the properties of waste immobilization glasses over a wide compositional region. Such prediction will speed glass composition development and aid in immobilization process design and operation. The compositional region of interest is large and more complex than systems normally reported in the scientific literature. The HLWIP has funded the development of statistical methods to produce empirical models of glass properties as a function of composition. The annual report for 1979 describes the first stages in the modeling of an 11-component glass system. At this time, 56 test compositions have been melted and their properties modeled; and 25 more test melts will be required to model chemical durability properties satisfactorily. Modeling results for viscosity, volatility, and crystallinity are reported in this document.

Table 5 shows the test matrix for the 11-component study. All melts contained $\mathrm{SiO}_{2}$, $\mathrm{B}_{2} \mathrm{O}_{3}$, and $\mathrm{Na}_{2} \mathrm{O}$. Fifty-five of the test compositions were selected from the corners (extreme verticies) of the test matrix, and six test melts were replicated from two to six times to determine the experimental error for each property.

Results of the viscosity, volatility, and crystallinity models are shown in the effects plots (Figures 7 through 9). The property value for the centroid composition of the matrix (1isted in Table 5) is plotted in the figures where the effect lines intersect. Each effect line shows the predicted change in property as the concentration of the corresponding component is changed from its concentration in the centroid. Standard prediction errors are computed for each point on the plots, and the largest and smallest of these are shown on the plots as bars representing \pm 1 standard error. Changes or differences on the plots smaller than +2 to 3 standard prediction errors are considered insignificant.

Viscosity measurements used to produce figure 7 were made using a rotating spindle technique. The figure shows that increasing the concentration of $\mathrm{Cr}_{2} \mathrm{O}_{3}, \mathrm{Fe}_{2} \mathrm{O}_{3} \mathrm{Al}_{2} \mathrm{O}_{3}$, or $\mathrm{SiO}_{2}$ in the glass increases the viscosity. $\mathrm{Na}_{2}, \mathrm{CaO}, \mathrm{MgO}, \mathrm{ZnO}$, and $\mathrm{TiO}_{2}$ decrease the viscosity. Both $\mathrm{NiO}$ and $\mathrm{B}_{2} \mathrm{O}_{3}$ produced negligible effects considering the size of their error bars. 
TABLE 5. Glass Composition Study Test Matrix

\begin{tabular}{lcccc} 
OXIDE & & \multicolumn{3}{c}{ STUDY VALUES (mole $\%)$} \\
\cline { 3 - 5 } FORMERS & & LOW & CENTROID & HIGH \\
$\mathrm{SiO}_{2}$ & 41 & 49.7 & 60 \\
$\mathrm{~B}_{2} \mathrm{O}_{3}$ & 5.5 & 9.1 & 15 \\
$\mathrm{Al}_{2} \mathrm{O}_{3}$ & 0 & 7.2 & 16 \\
MODIFIERS & & & \\
$\mathrm{Na}_{2} \mathrm{O}$ & & & \\
$\mathrm{MgO}$ & 9 & 12.7 & 17 \\
$\mathrm{CaO}$ & 0 & 3.9 & 9 \\
INTERMEDIATES & & 6.7 & 14 \\
$\mathrm{ZnO}_{\mathrm{TiO} O}$ & & & \\
$\mathrm{Cr}_{2} \mathrm{O}_{3}$ & 0 & 3.0 & 6.5 \\
$\mathrm{Fe}_{2} \mathrm{O}_{3}$ & 0 & 3.4 & 8 \\
$\mathrm{NiO}$ & 0 & 1.4 & 3.5 \\
& 0 & 1.5 & 3.5 \\
& 0 & 1.4 & 3.5
\end{tabular}

54 mole $\% \leq$ SUM OF FORMERS $\leq 80$ mole $\%$

$13 \mathrm{~mole} \% \leq$ SUM OF MODIFIERS $\leq 35$ mole $\%$

Fifty-six sodium borosilicate glass melts within this study matrix were tested for viscosity, volatility, crystal phase behavior, and leaching behavior. Properties were empirically modeled as a function of glass composition. Model results, shown in the figures on the following pages, show the effects of varying the composition from the centroid composition.

The effects of $\mathrm{Al}_{2} \mathrm{O}_{3}, \mathrm{SiO}_{2}, \mathrm{Na}_{2} \mathrm{O}, \mathrm{MgO}$, and $\mathrm{CaO}$ on viscosity can be explained from the classical interpretation of glass structure (Zachiarasen 1932). $\mathrm{SiO}_{2}$ and $\mathrm{Al}_{2} \mathrm{O}_{3}$ are formers acting to bind the oxide structure together in linked polyhedra, and they therefore act to increase viscosity. Sodium and the alkaline earths are modifiers that enter the structure by breaking $\mathrm{Si}-\mathrm{O}-\mathrm{Si}$ bonds. The polyhedra are then free to rotate at their unattached corners, causing a reduction in viscosity. Zno also acts as a modifier in this system judging by its viscosity decreasing effect, and $\mathrm{TiO}_{2}$ is considered an intermediate (Sun 1947 ).

Thus, depending on the competition for the available oxygen in the network, Ti can either form linked polyhedra or enter as a modifier. Based on its decreasing effect on viscosity, titanium acts as a modifier in this system. $\mathrm{Cr}_{2} \mathrm{O}_{3}$ and $\mathrm{Fe}^{2} \mathrm{O}_{3}$ act to increase viscosity by causing the formation of spinel crystals in the melt. Solid particles provide extra friction in melts undergoing shear movement.

Volatility data used to produce Figure 8 were obtained by measuring the weight loss from 2-g melts after heating at $1300^{\circ} \mathrm{C}$ for 3 hours. In a separate experiment performed on one third of the melts the vapor was collected on a cold finger and chemical analys is showed that $\mathrm{Cr}_{2} \mathrm{O}_{3}$ comprised only 0.5 to $2.6 \mathrm{wt} \%$ of the condensed vapor with $\mathrm{Na}_{2} \mathrm{O}$ and $\mathrm{B}_{2} \mathrm{O}_{3}$ comprising the remainder in nearly equal molar ratios. The fact that the $\mathrm{Na}_{2} \mathrm{O} / \mathrm{B}_{2} \mathrm{O}_{3}$ ratio in the vapor remains equal to one while it ranges from 0.92 to 2.67 in the different melts suggests that the vaporizing species is $\left(\mathrm{NaBO}_{2}\right) \mathrm{x}$. 


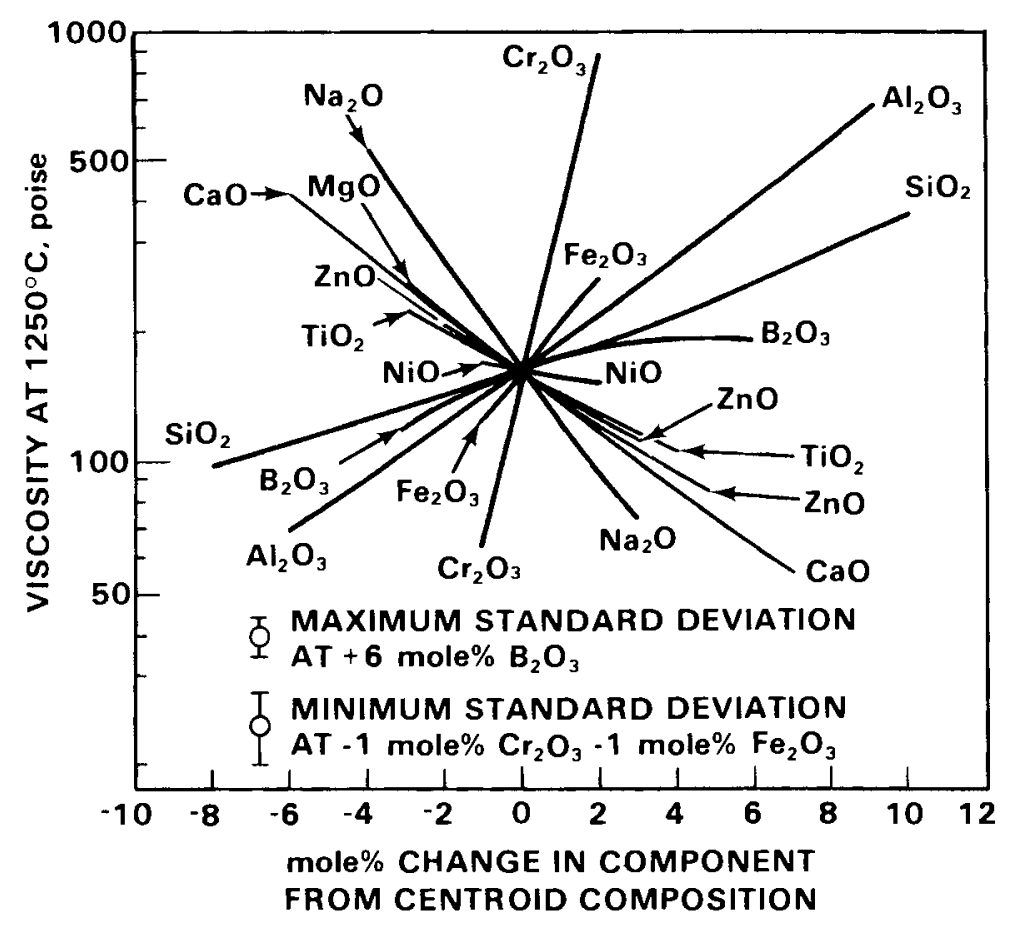

FIGURE 7. Effects of Glass Components on Viscosity at $1250^{\circ} \mathrm{C}$

Plot lines intersect at the viscosity of the centroid composition. Increasing the concentration of components whose effects lines have positive slopes will increase the viscosity of the glass. The magnitude of the slope indicates the relative tendency of the component to affect a change in viscosity. $\mathrm{Cr}_{2} \mathrm{O}_{3}$, then, has the strongest increasing effect while $\mathrm{Na}_{2} \mathrm{O}$ has the strongest decreasing effect on viscosity. Changes in the mole\% of $\mathrm{NiO}$ and $\mathrm{B}_{2} \mathrm{O}_{3}$ in the glass have insignificant effects on viscosity.

Many of the trends shown in the effects plot (Figure 8) can readily be explained. Since $\mathrm{Na}$ and $\mathrm{B}$ are the volatile elements, increasing their concentrations will increase volatility. Both the present study and an earlier one (submitted for publication in Radioactive Waste Management by W. J. Gray, PNL-SA-8136) show that there is a strong negative correlation between volatility and viscosity. Thus, things such as $\mathrm{Al}_{2} \mathrm{O}_{3}$ that increase viscosity (Figure 7) decrease volatility; $\mathrm{Na}_{2} \mathrm{O}$ and $\mathrm{CaO}$ decrease viscosity and hence increase volatility. The tendency of $\mathrm{Cr}_{2} \mathrm{O}_{3}$ to decrease volatility was expected since it increases viscosity and was found to volatilize in only trace amounts. Convection in the melt probably plays an important role in volatility by replenishing the depleted melt surface with $\mathrm{Na}_{2} \mathrm{O}$ and $\mathrm{B}_{2} \mathrm{O}_{3}$. Increased viscosity causes decreased convective currents and thus decreases volatility.

$X$-ray diffraction techniques were used to measure the total wt\% crystallinity in samples modeled to produce Figures $9(a)$ and $9(b)$. The specific phases formed were also identified. Figure $9(a)$ was produced by modeling crystallinity results from samples produced by 


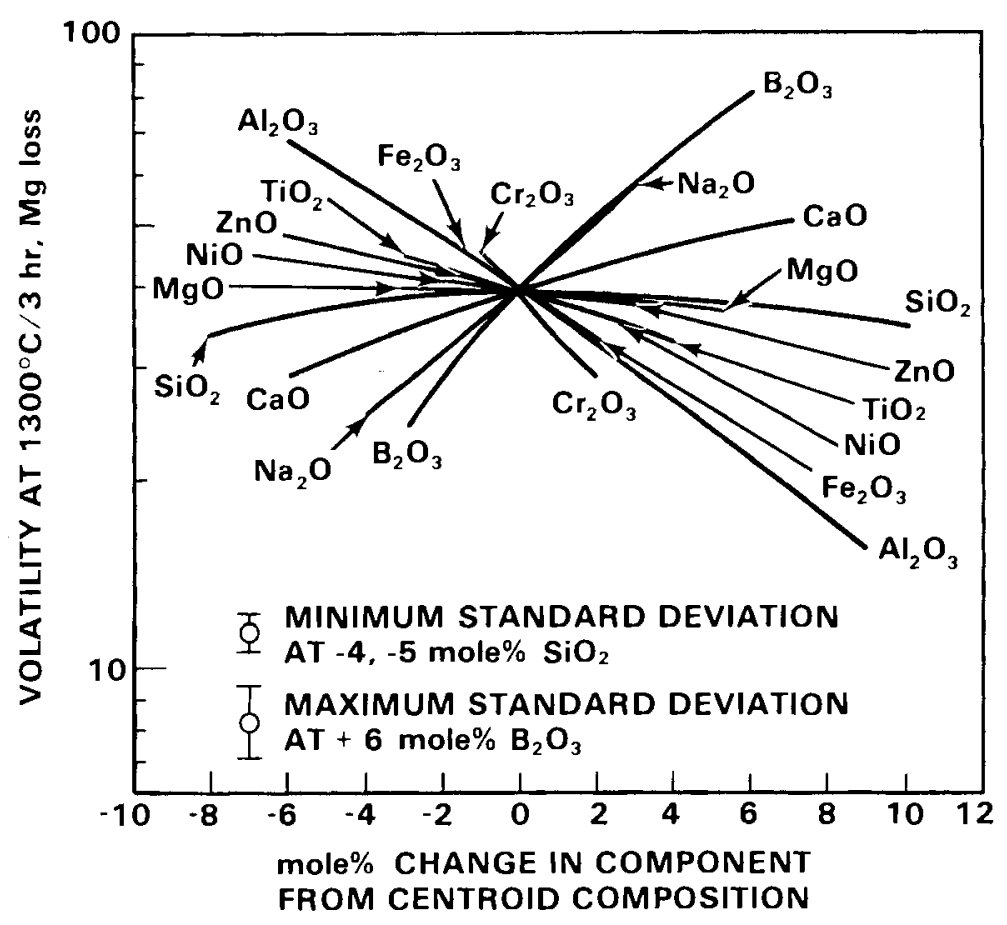

FIGURE 8. Effects of Glass Components on Volatility at $1300^{\circ} \mathrm{C}$

Empirical modeling of volatility versus composition shows that $\mathrm{B}_{2} \mathrm{O}_{3}$ and $\mathrm{Na}_{2} \mathrm{O}$ tend to increase volatility. Only sodium and boron were detected in significant amounts in escaping vapors. Apparently, sodium and boron form a volatile species with composition $\left(\mathrm{NaBO}_{2}\right) \mathrm{x}$ because sodium and boron were always detected in equamolar quantities in the vapor regardless of their ratio in the glass melt. $\mathrm{Cr}_{2} \mathrm{O}_{3}, \mathrm{Fe}_{2} \mathrm{O}_{3}$, and $\mathrm{Al}_{2} \mathrm{O}_{3}$ decrease volatility apparently because they increase the melt viscosity (see Figure 7). A strong negative correlation was found between volatility and viscosity for the compositions tested. Convection in the glass may play an important role in volatility by replenishing the depleted melt surface.

air quenching from the melt temperature. Slow cooling $\left(6^{\circ} \mathrm{C} /\right.$ hour $)$ from the melt temperature to $500^{\circ} \mathrm{C}$ followed by air quenching to room temperature was used to produce the samples modeled for Figure $9(b)$.

The devitrification phases that were observed in the slow-cooled specimens generally fall into one of four compositional or structural types: silicate, aluminate, titanate, or spinel-type structures frequently involving chromium. This last classification dominates in the air-cooled specimens but is usually a secondary phase in the slow-cooled specimens where formation of silicates seems to be favored.

The principal glass network former is silica, and it is not suprising that it suppresses devitrification in both air-quenched and slow-cooled specimens. Its effect of decreasing crystallinity, Figures $9(\mathrm{a})$ and $9(\mathrm{~b})$, has long been noted (Van Vlack 1964). $\mathrm{B}_{2} \mathrm{O}_{3}$ also decreases devitrification in the slow-cooled glasses, Figure $9(b)$, which is consistent with its role as a network former. 


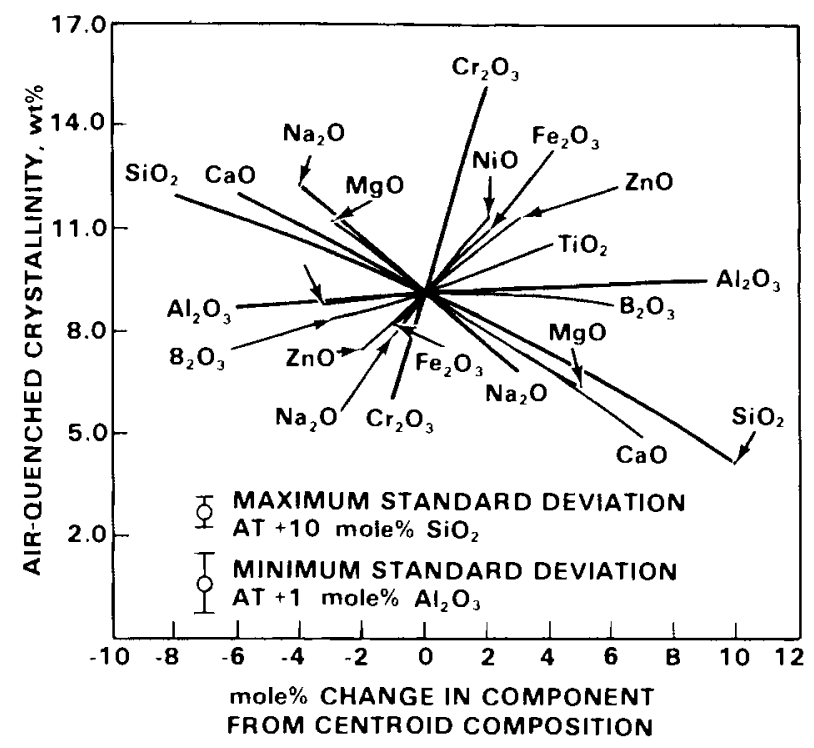

(a) Effects of Glass Components on Crystallity After Air Quenching

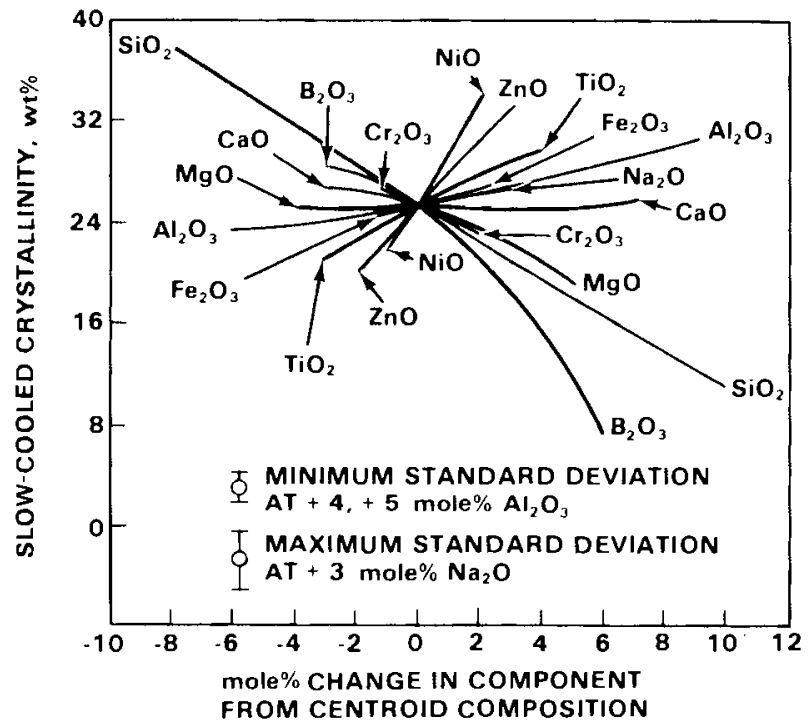

(b) Effects of Glass Components on Crystallity After Slow Cooling

FIGURE 9. Effects of Glass Components on Crystallity After Air Quenching and Slow Cooling

Empirical modeling of total wt\% crystallinity after both fast ( 5 minutes) and slow ( $\sim$ days) cooling from the melt temperature shows several differences in the effects of components. The primary crystalline products after air quenching from the melt are spinels containing $\mathrm{Cr}, \mathrm{Zn}, \mathrm{Mg}, \mathrm{Ti}, \mathrm{Ni}, \mathrm{Al}$, and $\mathrm{Fe}$ in decreasing order of overall concentration.

Except for $\mathrm{Al}$ and $\mathrm{Mg}$, addition of these components to the centroid glass increases crystallinity. Addition of sodium, the alkaline earths, or silicon decreases crystallinity after air quenching. After slow cooling, calcium, sodium, and silicon become important participants in the total crystallinity with the formation of sodium and calcium aluminosilicates. Boron, silicon, chromium, and magnesium have negative effects on total crystallinity after slow cooling. 
All five intermediates ( $\mathrm{NiO}, \mathrm{Cr}_{2} \mathrm{O}_{3}, \mathrm{TiO}_{2}, \mathrm{Fe}_{2} \mathrm{O}_{3}$, and $\mathrm{ZnO}$ ) increase crystallinity in the air-cooled glass, Figure $9(a)$, with the component slope reflecting the readiness with which each participated in the formation of crystalline phases. Although the effects of NiO, $\mathrm{TiO}_{2}, \mathrm{Fe}_{2} \mathrm{O}_{3}$, and $\mathrm{ZnO}$ change only slightly in going from air quenching to slow cooling, the effect of $\mathrm{Cr}_{2} \mathrm{O}_{3}$ changes from strongly increasing crystallinity in the air-quenched system to moderately decreasing crystallinity in the slow-cooled system. Apparently chromate inhibits further devitrification after its rapid nucleation and growth. $\mathrm{Al}_{2} \mathrm{O}_{3}$, which can act as a network former if sufficient alkali is present but which participates in some of the crystalline phases formed, has no significant effect on crystallinity in this system.

The three components that are network modifiers ( $\mathrm{CaO}, \mathrm{MgO}$, and $\mathrm{Na}_{2} \mathrm{O}$ ) strongly decrease crystallinity during air cooling, which can best be explained by observing that as modifiers they tend to destroy even the short-range order inherent to the glass and may make crystallization more difficult. Upon slow cooling, the tendency of $\mathrm{Na}_{2} \mathrm{O}$ and $\mathrm{CaO}$ to decrease crystallinity disappears due to their participation in calcium and sodium aluminosilicate phases.

Improving modeling techniques and expanding the matrix to include more components should result in predictive models that will allow faster optimization of glass formulation for specific nuclear wastes and for quantification of the effects of waste feed stream variability on immobilization product properties.

TRU Glass Development

Through January 1980 TRU glass development concentrated on compositions for vitrification of incinerator ashes. Incineration has been identified as a potential volume-reduction step for TRU-contaminated combustible trash. This ash may be generated at a number of locations including the LoS Alamos Scientific Laboratory (LASL) and the Rocky Flats Plant.

One characteristic of combustible TRU wastes is their wide potential compositional variation. The variety of materials to be incinerated includes lab coats, shoe covers, gloves, wipers, etc. All of these materials yield different oxides when burned, and normal changes in the proportions of the materials fed to the incinerator will lead to variations in the ash composition (Bryan and Palmer 1980). A waste form used for encapsulation of these ashes will be required to accommodate any anticipated variations in the makeup of the ash.

Borosilicate glass may be chosen as the waste form for these wastes. Certain oxides have limited solubilities in these glasses, which will limit the waste loading that may be achieved with a particular glass or limit the waste variation that may be accommodated at a particular waste loading, given fixed product performance specifications. Thus, a study was conducted of the solubilities of various waste oxide components in a typical borosilicate glass. In this study, each waste oxide was added individually to the base glass at various levels and its solubility limit was determined. The composition of the base glass and the oxides that were added are tabulated in Table 6, which indicates the solubility limit at $1050^{\circ} \mathrm{C}$ for the various oxides in this glass. Higher melting temperatures would result in increased solubilities for some components, such as $\mathrm{Al}_{2} \mathrm{O}_{3}$ and $\mathrm{Fe}_{2} \mathrm{O}_{3}$. Changes in the glass composition may also be made to increase solubilities. These changes, such as increased $\mathrm{B}_{2} \mathrm{O}_{3}$ or $\mathrm{Na}_{2} \mathrm{O}$, will tend to decrease the chemical durability of the product; and the final 
TABLE 6. Solubility Limits of Various TRU Waste 0xides in a Representative Borosilicate Glass Melted at $1050^{\circ} \mathrm{C}$

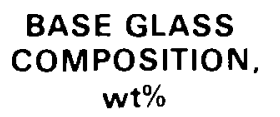

\begin{tabular}{lr}
\hline $\mathrm{SiO}_{2}$ & 59.0 \\
$\mathrm{Na}_{2} \mathrm{O}$ & 12.0 \\
$\mathrm{~B}_{2} \mathrm{O}_{3}$ & 15.0 \\
$\mathrm{CaO}_{\mathrm{ZnO}}$ & 4.3 \\
$\mathrm{~K}_{2} \mathrm{O}$ & 7.5 \\
& 2.2 \\
\hline
\end{tabular}

\section{SOLUBILITY LIMITS OF OXIDE ADDITIONS. wt $\%$ (a)}

\section{(a) REMAINDER IS REFERENCE GLASS}

One characteristic of TRU incinerator ashes is their wide potential compositional variation. Certain of the components have limited solubilities in borosilicate glass, as shown for a number of TRU ash components in a representative borosilicate glass. Higher melting temperatures or changes in glass composition may be used to increase the solubilities of certain oxides.

glass composition will reflect a balance between waste loading desired, compositional variation that can be incorporated, and chemical durability required. It should be noted that the presence of insoluble crystals or phase separation in TRU glasses is not necessarily detrimental. It may turn out that their effect on plutonium retention is negligible.

Figures 10 and 11 illustrate some properties of a glass developed for a particular incinerator ash produced by Rocky Flats; the composition of the glass is shown in Table 7 . The primary contribution of the ash is $\mathrm{SiO}_{2}$ and $\mathrm{Al}_{2} \mathrm{O}_{3}$, and the waste oxide loading of the glass is 30 wt $\%$.

Figure 10 shows how variations in the waste loading affect viscosity and electrical resistivity at $1050^{\circ} \mathrm{C}$. The increase in viscosity with ash loading is due to $\mathrm{SiO}_{2}$ and $\mathrm{Al}_{2} \mathrm{O}_{3}$ in the ash and dilution of $\mathrm{B}_{2} \mathrm{O}_{3}$ and the alkali oxides $\left(\mathrm{Na}_{2} \mathrm{O}, \mathrm{K}_{2} \mathrm{O}, \mathrm{Li}_{2} \mathrm{O}\right)$ in the frit. The increase in resistivity with loading is due to the dilution of the alkali oxides present in the frit. This is because the alkali ions are the major charge carriers in the glass.

Figure 11 shows how the chemical durability of the glass varies with changes in waste loading. Durability is enhanced with higher ash content due to $\mathrm{SiO}_{2}$ and $\mathrm{Al}_{2} \mathrm{O}_{3}$ contributed by the ash and the dilution of the $\mathrm{B}_{2} \mathrm{O}_{3}$ and alkali oxides present in the frit.

\section{KRYPTON-85 CONTAINING SOLID WASTE FORMS}

Krypton-85 is the only inert gas isotope generated in nuclear reactor fuels with a long enough half-life (10.7 years) to be considered for long-term storage. This isotope, however, is generated in sufficient quantities to be judged as having potential for increasing the overall worldwide base significantly. Therefore, regulations that will go into effect 


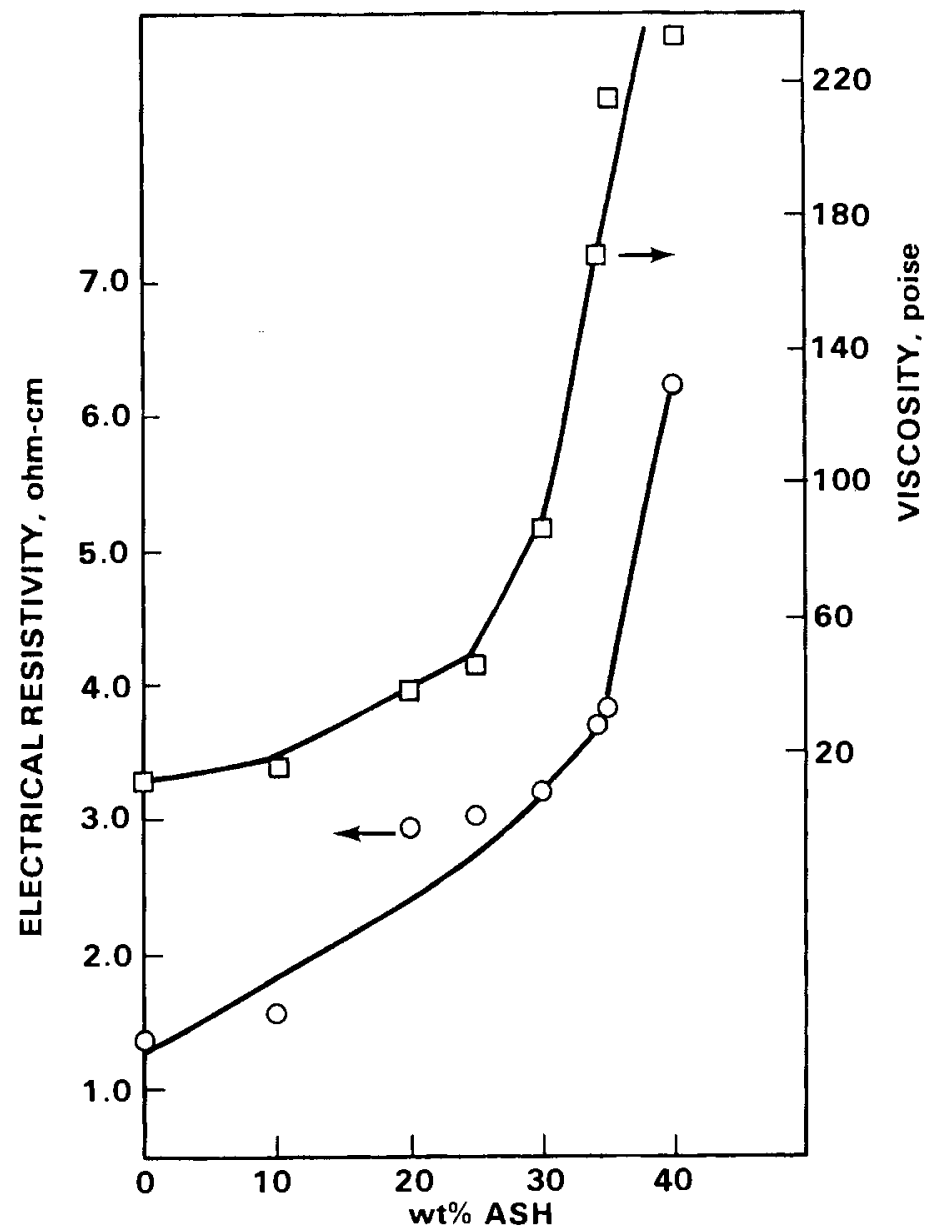

FIGURE 10. Electrical Resistivity and Viscosity of Glass $79-160$ at $1050^{\circ} \mathrm{C}$ as a Function of wt\% Ash

$\mathrm{SiO}_{2}$ and $\mathrm{Al}_{2} \mathrm{O}_{3}$ in the ash cause an increase in viscosity with ash addition to the glass. This increase is very rapid with additions over $25 \mathrm{wt} \%$. The increase in resistivity with ash content in glass $79-160$ is due to the dilution of the alkali ions present in the frit. Alkalis ( $\mathrm{Na}, \mathrm{K}, \mathrm{Li})$ are the major charge carriers in this glass.

in 1983 require that ${ }^{85} \mathrm{Kr}$ be captured and stored rather than released to the atmosphere. At present, the primary means of storing radioactive krypton is to compress the gas in pressurized gas storage bottles; however, because of the potential for accidental release of the pressurized gas, solid storage forms are being developed.

Work at PNL in the KSP has resulted in two particularly promising waste forms. One process involves ion implanting energetic krypton into sputter-deposited solids during the sputtering process. To date, we have demonstrated the ability to contain krypton in crystalline metals at concentrations of up to about $20-\mathrm{cm}^{3} \mathrm{Kr}(\mathrm{STP}) / \mathrm{g}$ of deposit (5 at.\%). 

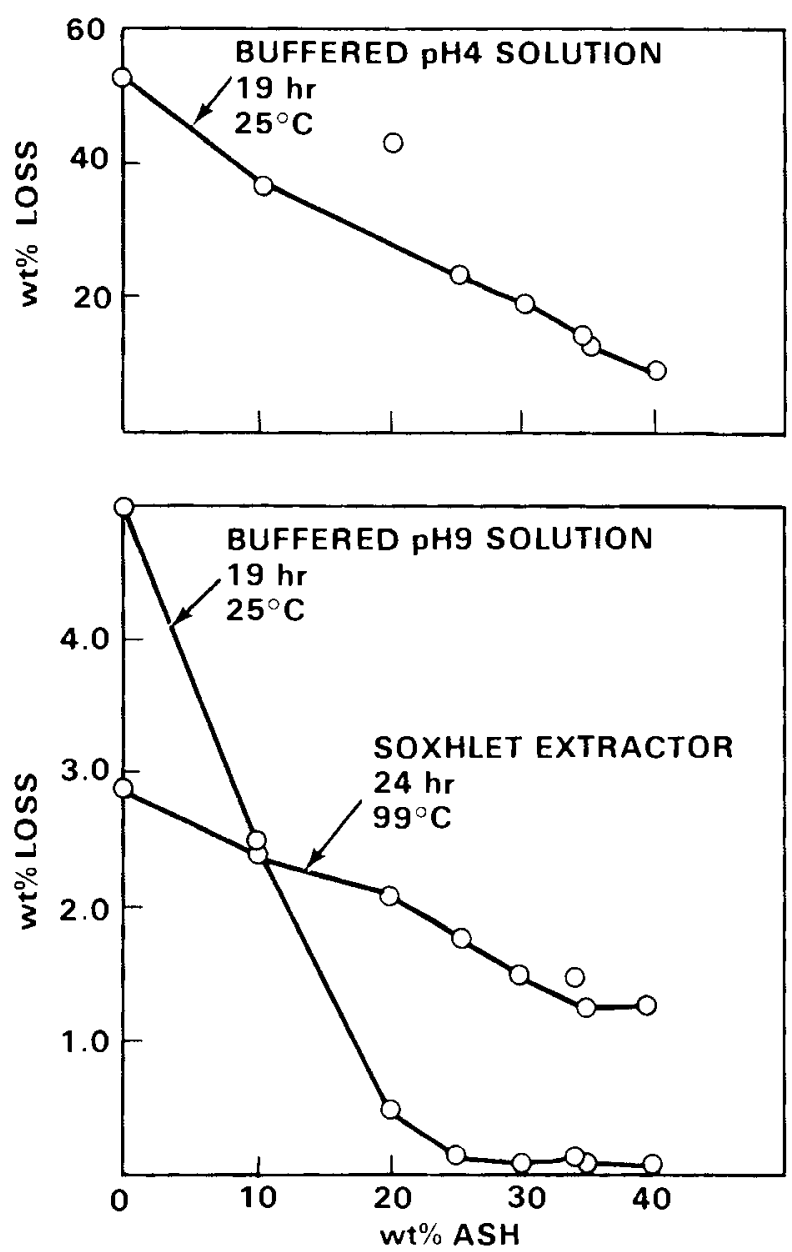

FIGURE 11. Leaching of Glass $79-160$ as a Function of wt\% Ash

One measure of the chemical durability of a waste glass is its weight loss in shortterm chemical durability testing. Crushed samples of glass 79-160 were tested in acidic and basic solutions at room temperature and in deionized water (Soxhlet extraction) at $\sim 99^{\circ} \mathrm{C}$. Increasing the ash content caused substantial decreases in the weight losses in all three tests due to the dilution of the readily soluble alkalis ( $N a, K, L i)$ and boron present in the frit and the increase in less soluble $\mathrm{Si}, \mathrm{Al}$, and $\mathrm{Ti}$ contributed by the ash.

When multicomponent metals are used that sputter to yield amorphous metals, deposits containing up to about $35-\mathrm{cm}^{3} \mathrm{Kr}$ (STP)/g of deposit (10 at.\%) have been produced. These deposits are extremely stable waste forms and permit higher krypton concentrations than any other waste form currently being considered (see Figure 12).

The second process involves loading very porous and high surface area glass rods with krypton at high pressures followed by sintering at high temperatures while maintaining the 
TABLE 7. Composition of Glass 79-160

\begin{tabular}{|c|c|c|c|}
\hline \multicolumn{4}{|c|}{$w t \%$} \\
\hline ELEMENT & IN FRIT & IN ASH & GLASS \\
\hline $\begin{array}{l}\mathrm{SiO}_{2} \\
\mathrm{~B}_{2} \mathrm{O}_{3} \\
\mathrm{Na}_{2} \mathrm{O} \\
\mathrm{Li}_{2} \mathrm{O}\end{array}$ & $\begin{array}{r}25.9 \\
11.9 \\
11.2 \\
2.0\end{array}$ & $\begin{array}{c}13.8 \\
- \\
- \\
-\end{array}$ & $\begin{array}{r}39.7 \\
11.9 \\
11.2 \\
2.0\end{array}$ \\
\hline $\begin{array}{l}\mathrm{K}_{2} \mathrm{O} \\
\mathrm{CaO} \\
\mathrm{TiO}_{2} \\
\mathrm{ZnO}\end{array}$ & $\begin{array}{l}4.0 \\
7.0 \\
4.0 \\
4.0\end{array}$ & $\begin{array}{l}- \\
\overline{1.3} \\
0.8\end{array}$ & $\begin{array}{l}4.0 \\
7.0 \\
5.3 \\
4.8\end{array}$ \\
\hline $\begin{array}{l}\mathrm{Al}_{2} \mathrm{O}_{3} \\
\mathrm{Fe}_{2} \mathrm{O}_{3} \\
\mathrm{BaO} \\
\text { OTHER }\end{array}$ & $\begin{array}{l}- \\
- \\
-\end{array}$ & $\begin{array}{r}11.0 \\
1.1 \\
0.4 \\
1.6\end{array}$ & $\begin{array}{r}11.0 \\
1.1 \\
0.4 \\
1.6\end{array}$ \\
\hline & 70.0 & 30.0 & $\overline{100.0}$ \\
\hline
\end{tabular}

krypton pressure. Using this process, loadings of $7-\mathrm{cm}^{3} \mathrm{Kr}($ STP $) / \mathrm{g}$ of glass have been achieved at a loading pressure of 5000 psi. Preliminary experiments indicate that higher loadings are achievable at higher pressures.

Gas release rates from the krypton-containing waste forms prepared by both of these techniques have been measured, and the gases are contained with only minimal release below $700^{\circ} \mathrm{C}$. For long-term storage very low leakage rates at much lower temperatures are of interest; therefore, leak rates have been measured for periods up to 190 days for the most promising waste materials. A summary of the results is given in Figure 13 . The release appears to be approximated by an equation of the form

$$
R=A t^{1 / 2}+B
$$

where $\quad R=$ the fraction of krypton released at time $t$

$A, B=$ constants equal to the slope and intercept, respectively (determined from Figure 13).

As seen in the figure, leakage rates from all of these materials are low enough to be of no significant consequence at temperatures anticipated for waste storage. With such waste forms available, it now appears that solid state storage of ${ }^{85} \mathrm{Kr}$ will become the favored procedure. 


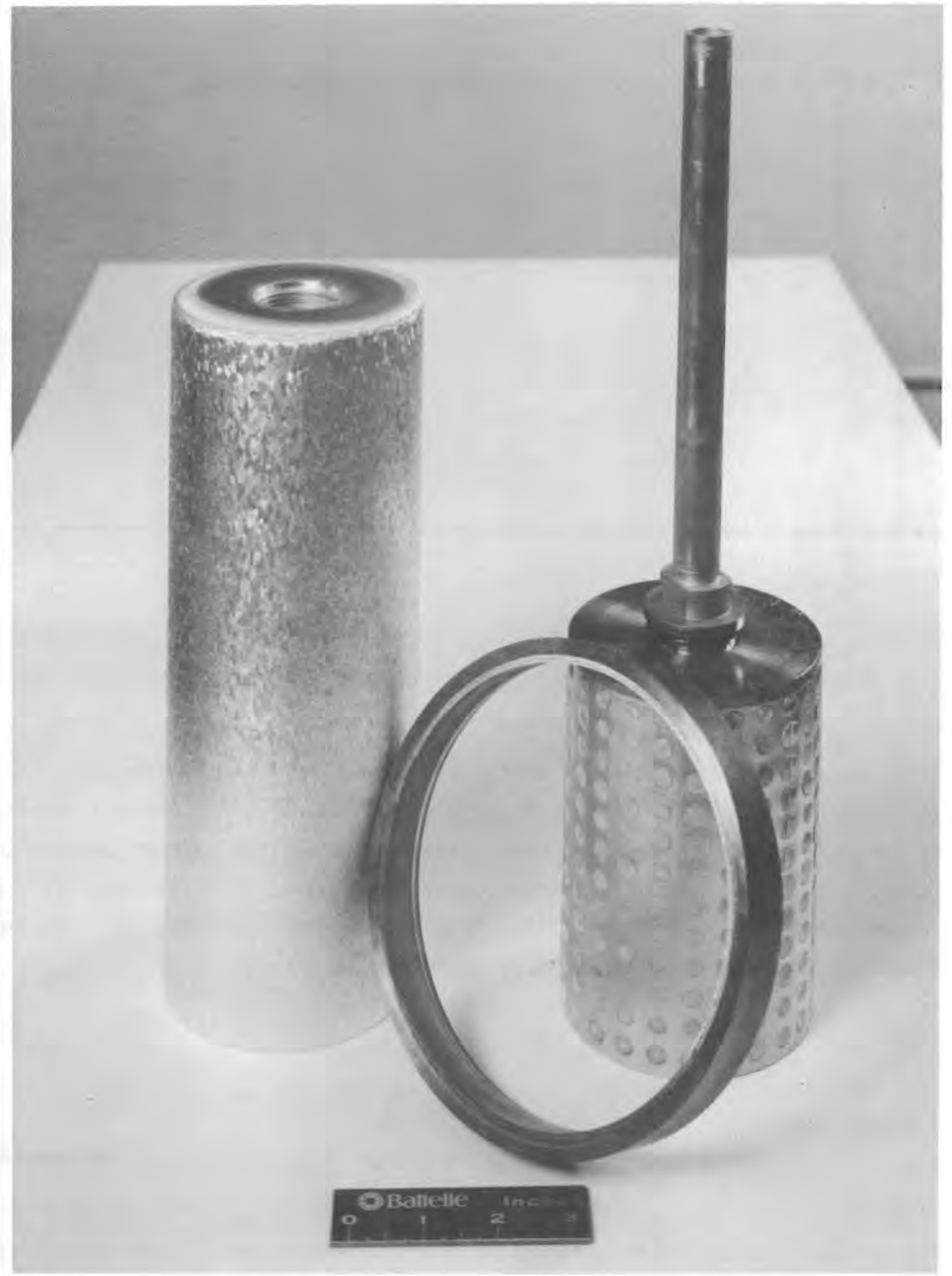

FIGURE 12. Sputter-Deposited Metal Krypton Waste Forms

Several radioactive inert gas isotopes are produced in nuclear reactor fuel. of these only $85 \mathrm{Kr}$ has a lifetime long enough to require long-term storage. A process has been developed at PNL in which $85 \mathrm{Kr}$ is implanted into a solid matrix by bombarding a sputtered metal deposit with energetic krypton ions. The stainless steel (SS) target used for sputtering a crystalline SS deposit containing 2 at.\% krypton is shown on the left side. Several other crystalline solids have been sputtered that contained between 2 and 5 at.\% krypton. A composite target made by inserting small yttrium plugs into an iron target is shown on the right. This target sputters to produce an amorphous deposit containing about 9 at.\% krypton. A small section cut from a 2-mm thick SS deposit sputtered on a copper substrate is shown in the center. 


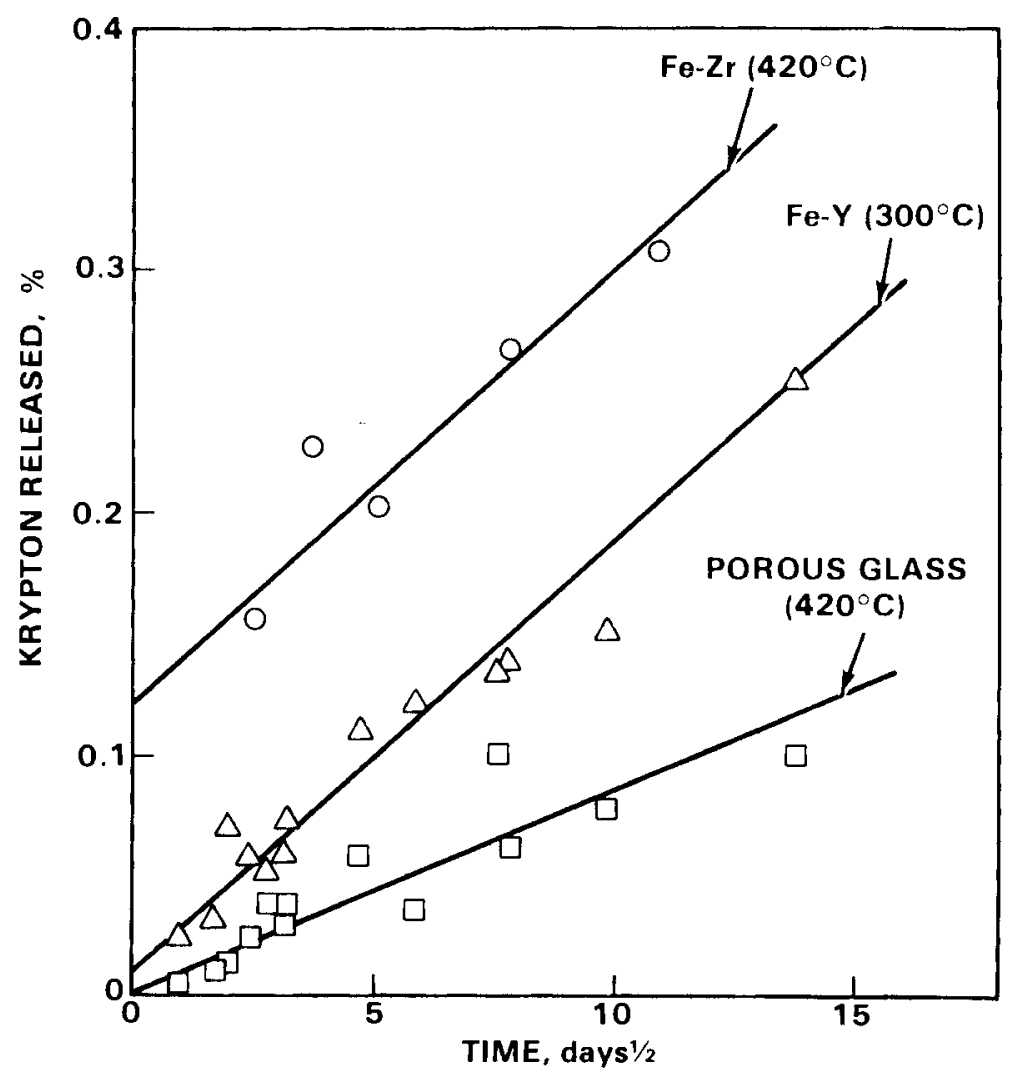

FIGURE 13. Krypton Release from Three Waste Forms

Long-term gas release measurements have been conducted on two sputter-deposited metals and on a porous glass loaded under 5000-psi pressure and sintered at $850^{\circ} \mathrm{C}$. The gas release for all three materials appears to increase linearly with the square root of time. Extrapolation of these data yields the fraction released after 10 years as follows:

$$
\begin{aligned}
\text { Fe-Zr alloy } & =1.2 \% \text { at } 420^{\circ} \mathrm{C} \\
\text { Fe-Y alloy } & =1.1 \% \text { at } 300^{\circ} \mathrm{C} \\
\text { Porous glass } & =0.5 \% \text { at } 420^{\circ} \mathrm{C}
\end{aligned}
$$

Since these temperatures are considerably higher than anticipated in active storage, the krypton released from any of these waste forms would be of little consequence. 


\section{LEACHING INVESTIGATIONS}

Historically, the emphasis of investigations of waste form leaching behavior has tended toward data gathering and support for process development. More recently, effects of varying the leachant, the temperature, and the rate of leachant flow have been investigated. This year, the emphas is has shifted even more toward understanding waste form/aqueous solution interactions rather than generating additional leaching data. The work is directed toward understanding and modeling long-term waste form behavior under potential life cycle and disposal conditions. New areas of research include surface analyses with elemental depth profiling, electropotential variations of the glass surface relative to the solution, radiolys is effects on leaching characteristics, and interactions between geologic media and waste forms during leaching.

\section{FUNDAMENTAL LEACHING PHENOMENA}

The interaction of glass and water has been investigated for many years. For simple glasses there are initial reactions that predominantly involve ion exchange and later reactions that are dominated by hydroxyl attack. The initial ion exchange reactions cannot be agreed upon. There are two schools of thought that prevail: 1) that $\mathrm{H}^{+}$ions exchange with the alkali ions in the glass (Douglas and El-Shamy 1967; Sanders and Hench 1973) or 2) that $\mathrm{H}_{3} \mathrm{O}^{+}$rather than $\mathrm{H}^{+}$exchanges (Tomozawa and Doremus 1979).

In principle it should be possible to determine the $0 / \mathrm{Si}$ ratio through the reaction layer and thus differentiate between $\mathrm{H}^{+}$and $\mathrm{H}_{3} \mathrm{O}^{+}$ion exchange. This has been done for a $\mathrm{Na}_{2} \mathrm{O} \cdot 3 \mathrm{SiO}_{2}$ glass using electron spectroscopy for chemical analysis (ESCA) in conjunction with ion milling to determine elemental concentrations through the reaction layer of the glass. Concentration profiles are shown in Figure 14(a) for a 15-min exposure of the glass to static deionized water at $25^{\circ} \mathrm{C}$ with sample SA/SV equal to $10 \mathrm{~m}^{-1}$. If $\mathrm{H}^{+}$is replacing the $\mathrm{Na}^{+}$ions, then the $0 / 5 \mathrm{i}$ ratio should remain constant; however, if $\mathrm{H}_{3} \mathrm{O}^{+}$is ion exchanging with $\mathrm{Na}^{+}$, then the $0 / S i$ ratio will increase proportionally to the $\mathrm{Na}^{+}$depletion.

In Figure $14(b)$ the solid circles represent the determined $0 / 5 i$ ratios. There is a slight enhancement at the very surface, which is believed to be due to hydroxide formations on the surface. The open circles represent the behavior that would be expected if $\mathrm{H}_{3} \mathrm{O}^{+}$were ion exchanging with $\mathrm{Na}^{+}$. The evidence from this set of experiments points to $\mathrm{H}^{+}$rather than $\mathrm{H}_{3} \mathrm{O}^{+}$ion exchange.

When a glass sample is immersed in an aqueous solution, its surface reacts with the solution and generates an electrical potential difference between the glass surface and the solution. This potential difference can cause enhanced diffusion of the ionic species and thus result in accelerated glass-water interactions (Mularie, Furth, and Westwood 1979). The experimental apparatus used to measure this surface potential is illustrated in Figure 15(a).

Two platinum electrodes are immersed in a solution and connected through a highimpedance $\left(10^{14}-\mathrm{ohm}\right)$ electrometer. These electrodes should have no electrical 


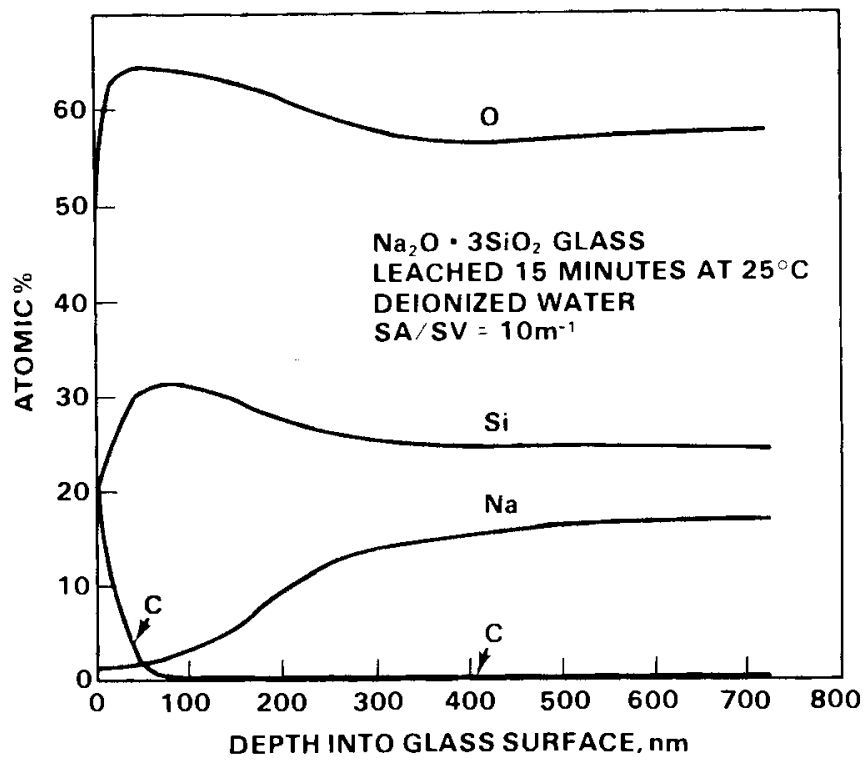

(a) Concentration Profiles

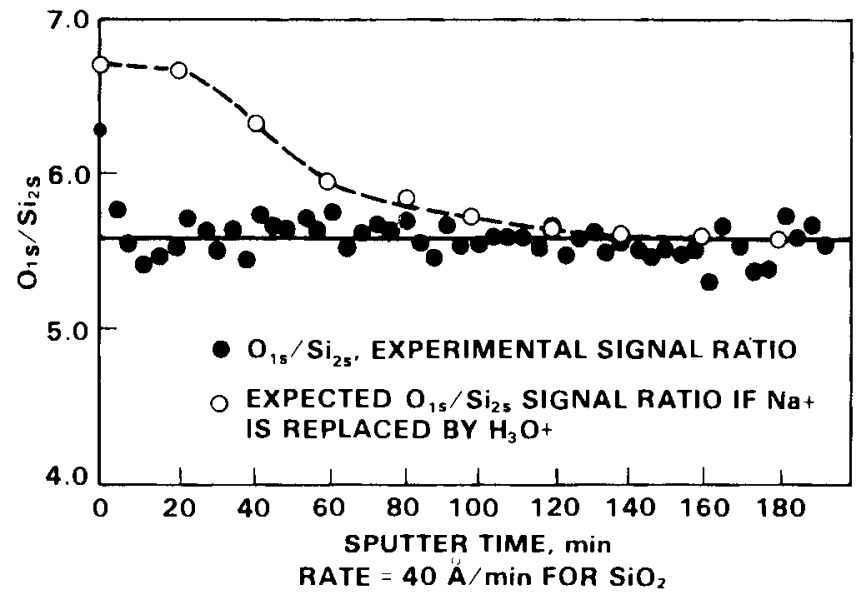

(b) Oxygen-to-Silicon Ratio Profiles

FIGURE 14. Ion Exchange of Hydrogen Species with Sodium in a Simple Glass

Hydrogen species from water are known to ion exchange with alkali ions in glasses. There has been controversy in the literature, however, on whether the exchange involves $\mathrm{H}^{+}$ or $\mathrm{H}_{3} \mathrm{O}^{+}$. The ESCA technique sputters away the leached glass surface in steps and analyzes the chemical composition of the exposed surface after each step. The ESCA elemental sputter profile for leached $\mathrm{Na}_{2} \mathrm{O} \cdot 3 \mathrm{SiO}_{2}$ glass illustrates that sodium is depleted from the leached surface to a much greater depth than silicon (carbon is a contaminant on the glass surface).

In the oxygen-to-silicon ratio for the same glass the solid circles represent $0 / 5 i$ ratios as a function of depth into the sample as determined from the first illustration. The open circles represent the expected or calculated $0 / \mathrm{Si}^{2}$ atios if $\mathrm{Na}^{+}$is replaced by $\mathrm{H}_{3} \mathrm{O}^{+}$. There is a large discrepancy between expected and observed results; therefore, one can say with reasonable confidence that simple glass-water interactions at $25^{\circ} \mathrm{C}$ do not involve $\mathrm{H}_{3} \mathrm{O}^{+}$ion exchange for $\mathrm{Na}^{+}$. 


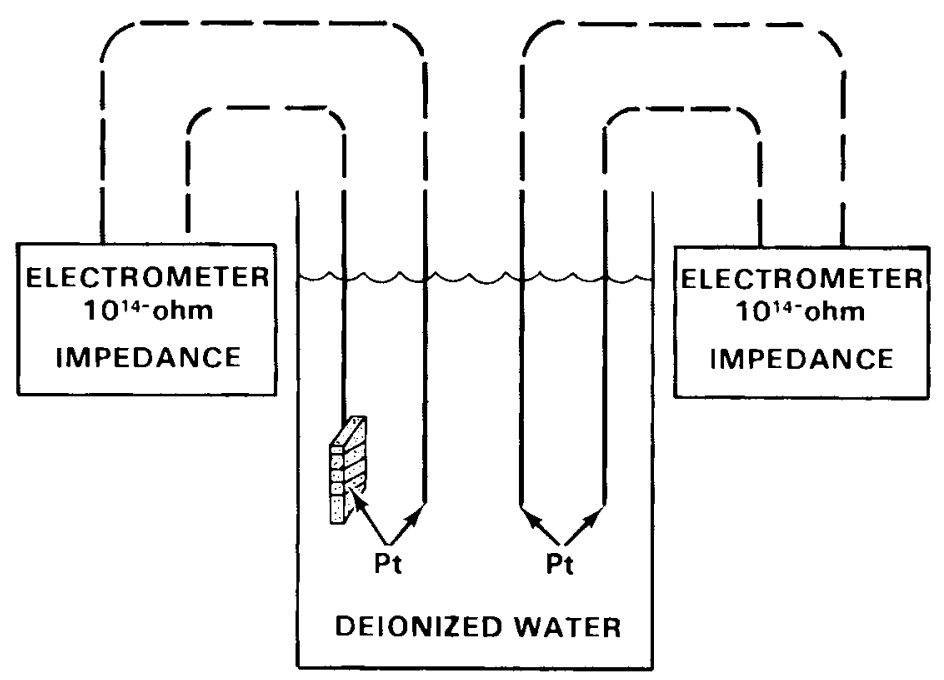

(a) Schematic of Surface Potential Apparatus

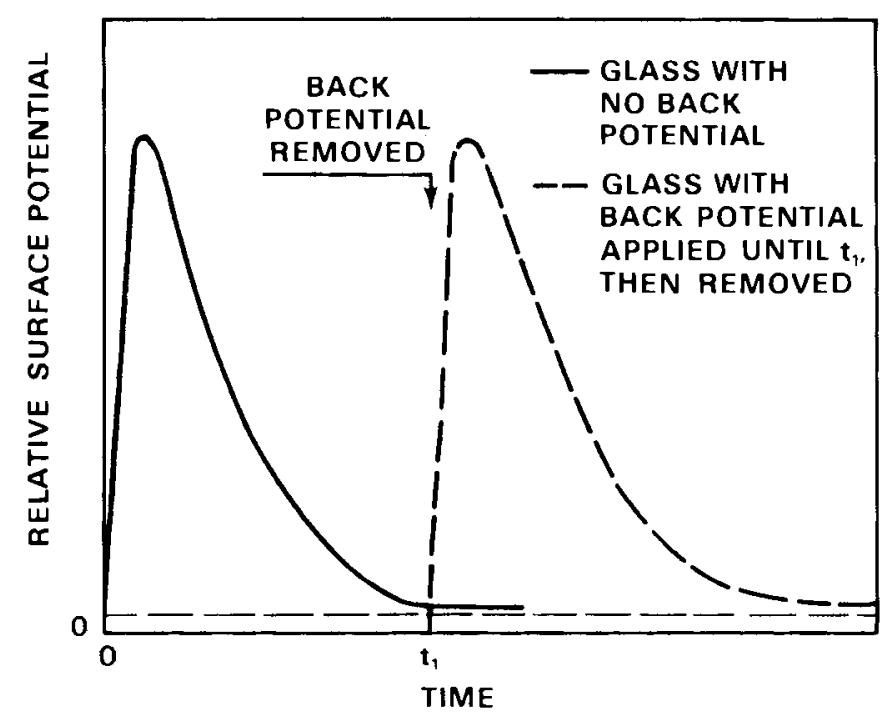

(b) Time Dependence and Effect of Back Potential

FIGURE 15. Phenomena of Electrical Surface Potentials on Glass During Leaching

Electrical surface potentials that develop on glass surfaces during leaching were measured, see Figure 15(a). The two platinum (Pt) electrodes on the right serve as a reference and should have zero potential between them. The two on the left are identical except that a glass sample is bound to one electrode with fine Pt wire. Any potential that is generated on the glass surface as a result of glass-water interactions is measured relative to an electrode in the solution.

When the time dependence for a surface potential on a simple glass was measured, Figure $15(\mathrm{~b})$, the potential rose rapidly to a characteristic value, then slowly dropped. After time $t_{1}$, the surface potential was at a steady-state value near zero. The dashed line illustrates what happens if a fresh sample is placed in water with a back potential applied. The potential generated on the surface is exactly nullified until time $t_{1}$ when the back potential is removed. The sample behaves as if it had just been placed in water, which illustrates that glass-water interactions can be electronically delayed. 


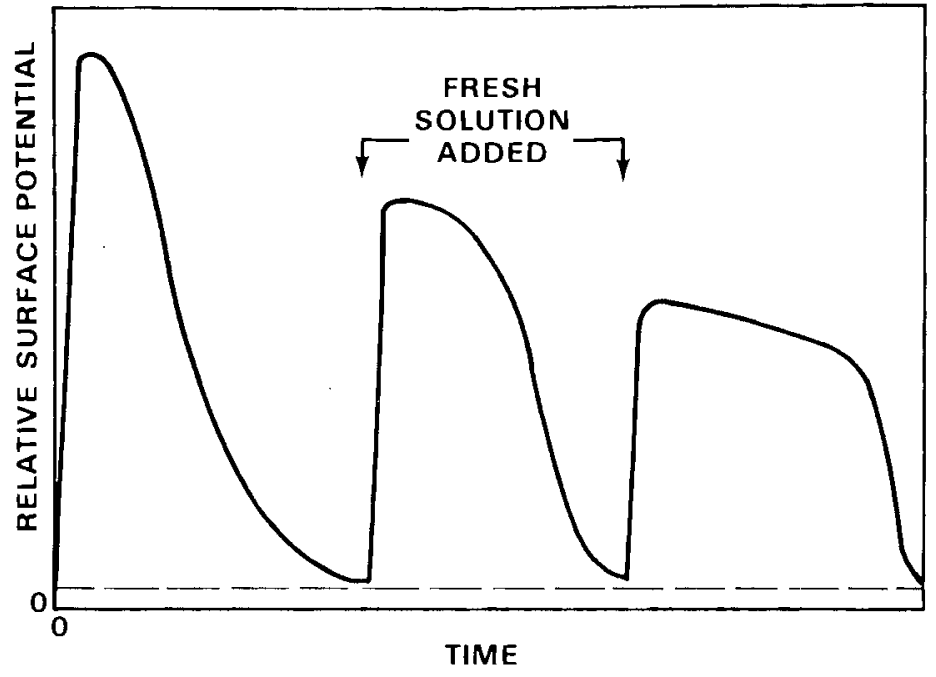

(c) Effect of Changing Solution

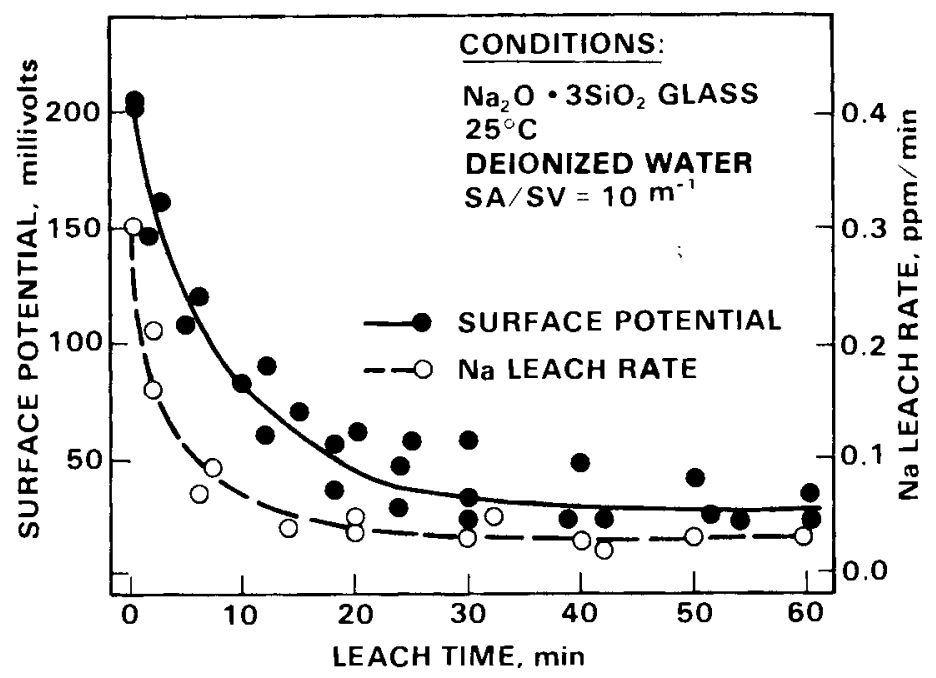

(d) Correlation of Leach Rate and Surface Potential

\section{FIGURE 15. (Contd)}

Figure 15(c) illustrates surface potential characteristics as a function of refreshing the leachate solution. This leachate replacement results in the generation of a new surface potential each time. This new potential is not as high as the original one and remains on the sample surface longer. However, it always appears and could explain enhanced leaching observed in dynamic leach tests. Figure $15(\mathrm{~d})$ illustrates the correlation between measured surface potentials and leach rates for sodium in a $\mathrm{Na}_{2} \mathrm{O} \cdot 3 \mathrm{SiO}_{2}$ glass at $25^{\circ} \mathrm{C}$ in distilled and deionized water with a sample SA/SV ratio of $10 \mathrm{~m}^{-1}$. The surface potential measurements contain data from three samples, while each point on the leach rate curve represents a new sample. It is clear that leach rates and surface potential have similar time dependencies. Apparently, high surface potentials result in high leach rates; while low surface potentials result in low leach rates. 
potential between them if everything is cleaned, assembled, and working properly. However, when a glass sample is attached to one of these electrodes by a fine platinum wire, an electrical potential difference develops between the glass surface and the reference electrode in the solution. The relative magnitude of this potential difference is shown schematically on the left side of Figure 15(b). The surface potential increases rapidly to a maximum value, and then drops to some steady-state value near zero at time $t_{1}$. The magnitude and duration of the surface potential depends on the reaction rate of the glass with the solution. For simple glasses, such as $\mathrm{Na}_{2} \mathrm{O} \cdot 3 \mathrm{SiO}_{2}$, the surface potential reaches approximately $200 \mathrm{mV}$ and takes a few hours (depending upon temperature) to reach a steady-state value. More complex glasses, such as 76-68, do not achieve as high a value for the surface potential (approximately $140 \mathrm{mV}$ ); but the rate drops off more slowly (days at lower temperatures).

It is possible to retard or hold off the reaction between glass and water by applying a back potential exactly equal to but opposite in sign to that generated by the glass-water interaction, i.e., maintain the potential on the glass surface at zero. This is illustrated on the right side of Figure 15(b), where a back potential was maintained on the glass in solution until time $t_{1}$ (zero surface potential) and then removed. Upon removal of the back potential, the glass reacted as if it had just been placed in solution. This phenomenon occurred for every type of glass tested.

Furthermore, if the leachate is replaced at time intervals with fresh solution, a new surface potential develops each time, see Figure 15(c). The new potentials are not as large as the initial surface potential but remain for longer periods of time. Apparently, a fresh solution reacts more with glass surfaces than a solution containing reaction products. Perhaps this is why dynamic leach tests have higher sustained leach rates than static leach tests.

The correlation between leach rates and surface potential has been made for a $\mathrm{Na}_{2} \mathrm{O} \cdot 3 \mathrm{SiO}_{2}$ glass, see Figure $15(d)$. Sodium leach rates were determined by solution analyses on static leach tests in distilled water (each point is a different sample). Surface potential measurements were made in a static distilled water environment, and data were taken from three surface potential curves for three different samples. As can be seen in Figure $15(d)$, the correlation between surface potential and leach rate is good. A high surface potential corresponds to a high leach rate and the drop-off rate of surface potential and leach rate is essentially identical.

When the surface potential drops to a low constant value, it does not mean that leaching has stopped but rather that the initial rapid leach rate has slowed to a steadystate value. Surface potential measurements have been successfully used to determine relative durabilities of glasses and could possibly be used to aid in selecting optimum backfill and overpack materials by monitoring their effect on glass leaching. Additionally, it is possible to slow or stop glass-water reactions by applying back potentials. However, one must bear in mind that glass is an insulator and the back potential only affects the region of glass close to the platinum wire wrap. 
Immersion of a glass surface in water causes an interaction that is dominated by the solution characteristics in the region near the glass and not by bulk solution characteristics. An apparatus, illustrated in Figure 16(a), was constructed to extract small volumes of solution at the sample surface and in the bulk solution to determine the difference between their $\mathrm{pH}$ values. This apparatus utilizes capillary tubes to extract $0.5 \mathrm{ml}$ of solution at a time. Solution is extracted only once from each region on the glass surface during the experiment.

The glass used for this experiment was a soda-lime-silicate immersed in $75^{\circ} \mathrm{C}$ distilled water at an SA/SV of $10 \mathrm{~m}^{-1}$. Solution was extracted at time intervals and the $\mathrm{pH}$ was measured immediately. The results, shown in Figure 16(b), are from two identical experiments using two different samples. As can be seen, the pH of the solution near the glass-water interface increases more rapidly and reaches a higher value than the pH of the bulk solution. After one day the leach rate decreases and the bulk and surface solution $\mathrm{pH}$ values come closer together. The surface potential, also shown in Figure 16(b), corresponds more closely with the glass-water interface $\mathrm{pH}$ than with the bulk $\mathrm{pH}$ values. This was expected from a measurement that is primarily sensitive to the sample surface.

\section{LEACHING ENVIRONMENTAL. EFFECTS}

Leaching conditions play a dominant role in the rates and characteristics of glass-water interactions. No single leach test can reveal the total behavior of a waste form in solution. Figure 17 illustrates the different results obtained for static and dynamic leaching systems. Crushed samples of glass 72-68 were leached in deionized water at $25^{\circ} \mathrm{C}$. The dynamic leaching test approximates a continuously flowing solution test since the sample is periodically removed from solution and placed in fresh solution. In the static test, the sample remains in the original solution and small portions of the solution are periodically withdrawn for analysis.

Release rates for strontium, Figure 17(a), and cesium, Figure 17(b), are higher in dynamic tests than in static tests by about a factor of 5 . This result might be explained by the enhanced surface potential resulting from fresh solution, see Figure $15(c)$. The higher surface potential generated in the dynamic test would result in larger leach rates for the dynamic test than for the static test.

The effects of varying the leachate composition on leaching characteristics have also been investigated. Leach tests were conducted using a modified version of the International Atomic Energy Association (IAEA) procedure to study the behavior of waste glass-solution interactions (Bradley 1980). Simulated high-level waste glass 76-68 was doped with the amounts of technetium, uranium, neptunium, plutonium, americium, and curium expected to be present in high-level waste. These elements constitute most of the potential long-term biological hazard associated with nuclear wastes.

The glass was doped with these elements (some on a single dopant basis) to study their behavior in detail without radiochemical interferences and radiation fields that would be 


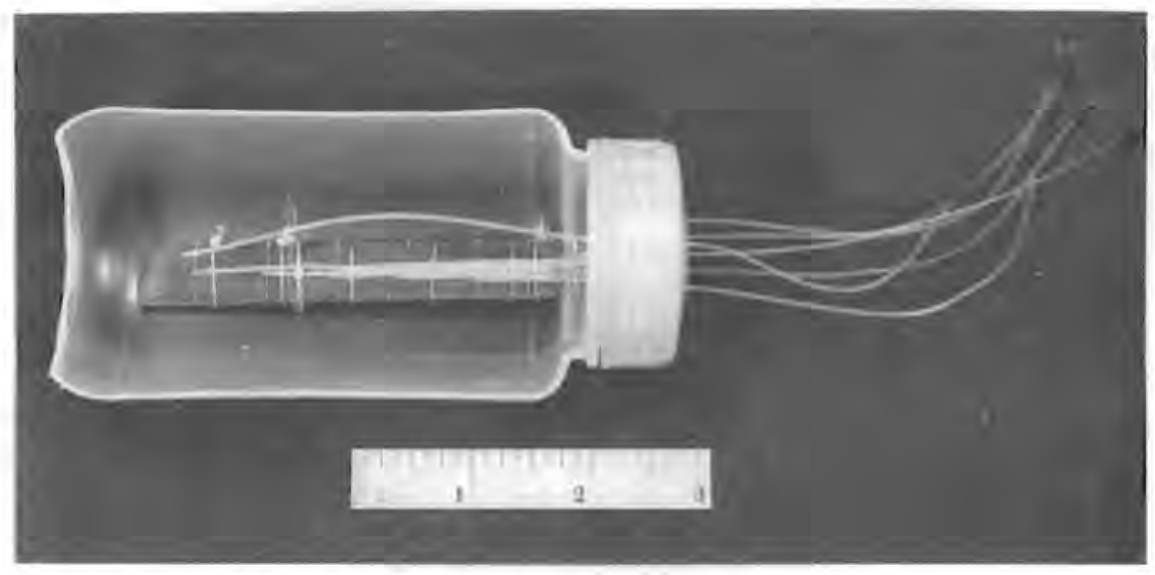

(a) Apparatus to Measure Solution $\mathrm{pH}$

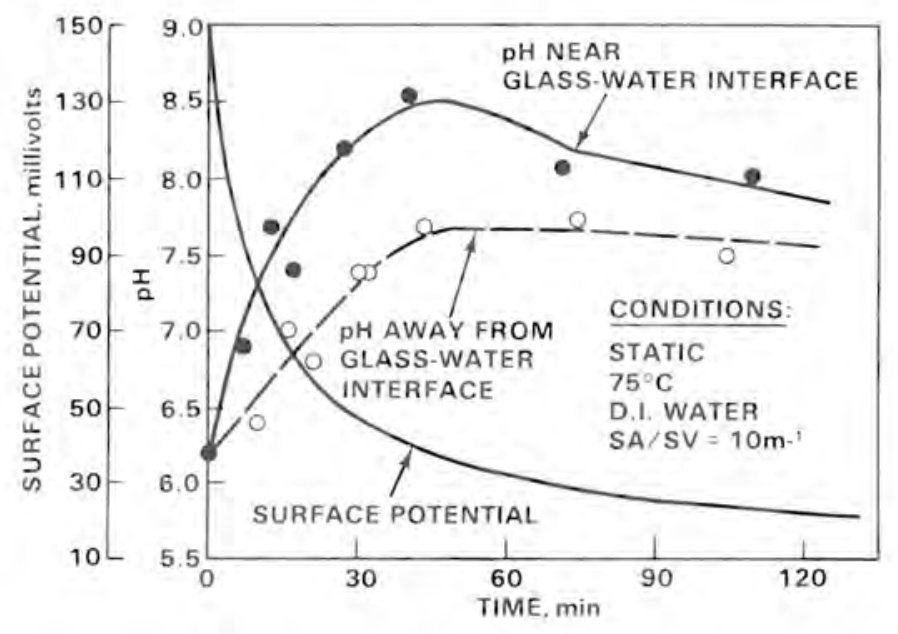

(b) Measurements of Solution pH

FIGURE 16. Measurement of $\mathrm{pH}$ Versus Time Near and Away from the Glass Surface

Glass-water interaction changes the $\mathrm{pH}$ of the solution, and the rate of this change is analagous to the leach rate: rapid at first and subsequently slower.

The apparatus determines the solution $\mathrm{pH}$ adjacent to and away from the glass surface (bulk). Solution samples (0.5-ml volume) were removed through capillary tubes at time intervals, and $\mathrm{pH}$ measurements were made. At each sampling time, a sample was taken from both the bulk solution and the water-glass interface. Each capillary tube adjacent to the glass surface was used only once. The glass was a soda-lime-silicate leached at $75^{\circ} \mathrm{C}$ in distilled and deionized water at an SA/SV ratio of $10 \mathrm{~m}^{-1}$. The $\mathrm{pH}$ of the solution taken near the glass surface (solid curve) was higher than that taken in the bulk solution (dashed curve). After one day, the two pH values were the same.

The $\mathrm{pH}$ changes most rapidly and the difference between bulk and surface $\mathrm{pH}$ values are the largest during the initial time period when the surface potential and leach rates are high. As the surface potential drops off, so does the leach rate. The pH rate of change then declines, and differences between $\mathrm{pH}$ values at the interface and at the bulk become smaller. This effect is apparently due to a wave of ions released during the initial fast leaching that move through the solution and become homogeneously dispersed. 


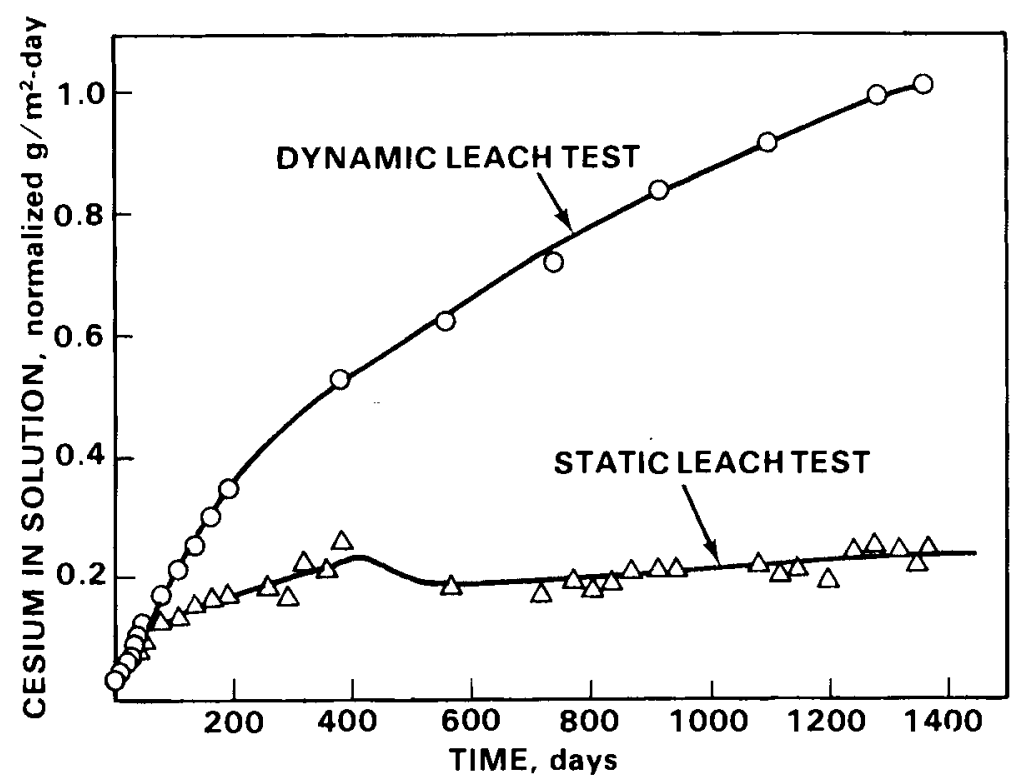

(a) Strontium Release Rates

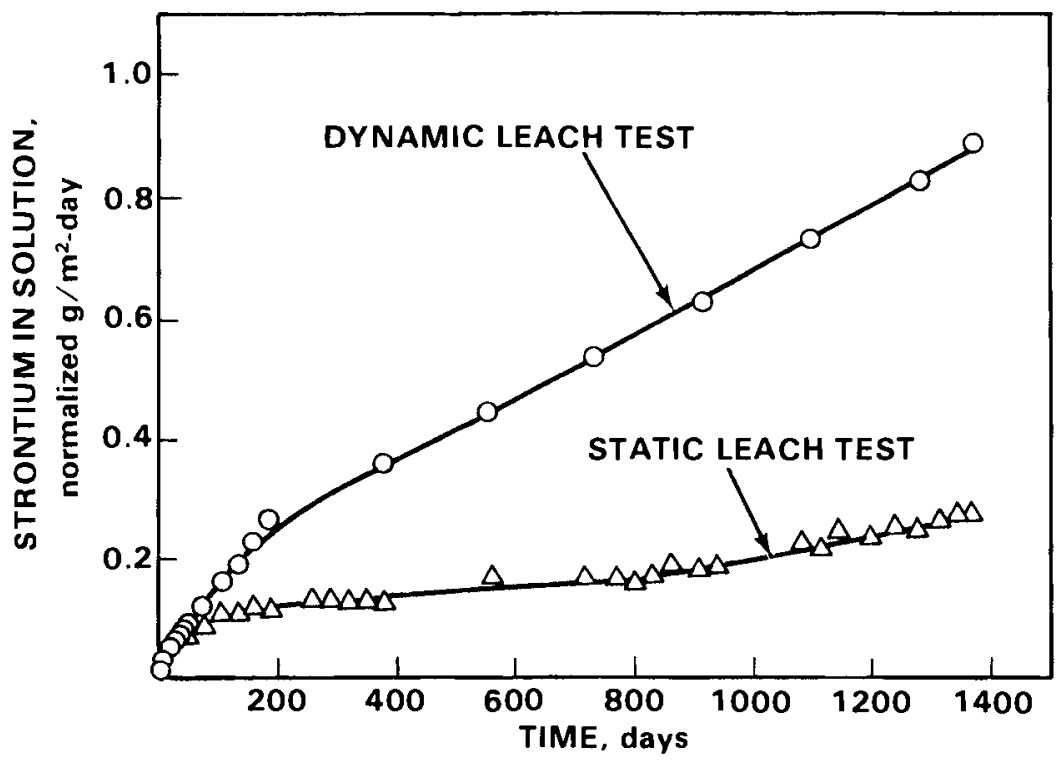

(b) Cesium Release Rates

FIGURE 17. Static Versus Dynamic Leaching Tests

Because no single leach test can reveal the total behavior of a waste form in solution, both static and dynamic (flowing) tests were conducted. Crushed samples of glass 72-68 were leached in deionized water at $25^{\circ} \mathrm{C}$. In static testing the sample remains in the original solution and small portions of the solution are periodically withdrawn for analysis. The dynamic leach test approximates a continuously flowing solution test since the sample is periodically removed from the solution and placed in fresh solution. Release rates for strontium and cesium (the elements tested) are higher by a factor of 5 in the dynamic testing mode. 
encountered with a fully radioactive waste. Future tests will include a limited amount of work with these elements associated with fully radioactive wastes so that their behavior can be verified.

Release rates were determined for technetium, uranium, neptunium, plutonium, americium, curium, and silicon in the following solutions:

- WIPP B salt brine, $\mathrm{NaCl}(287 \mathrm{~g} / 1)$

- $\mathrm{NaCl}(1.76 \mathrm{~g} / \mathrm{l})$

- $\mathrm{CaCl}_{2}(1.66 \mathrm{~g} / 1)$

- $\mathrm{NaHCO}_{3}(2.52 \mathrm{~g} / 1)$

- deionized water.

The following conclusions were made as a result of this study:

- Release rates of the actinide elements were lower than those of silicon in all cases except for neptunium, which had a release rate comparable to silicon, see Figure $18(\mathrm{c})$.

- Leach rates decrease by an order of magnitude during the first 20 to 30 days of solution contact, which is consistent with previous studies; see Figure 18(a) for plutonium leach rates.

- The range of leach rates for the different solution types studied spans one order of magnitude.

- Technetium is phase-separated in the glass and concentrates on the pore surfaces within the glass matrix. Although it is in an apparent soluble form, its release will be controlled by dissolution of the silicon matrix.

- After over 400 days of leaching at $25^{\circ} \mathrm{C}$, a glass surface reaction zone cannot be optically observed at $400 x$ magnification although there is surface discoloration.

- The leach rate of actinides appears to have a small dependence on how frequently solutions are changed in the modified IAEA leaching procedure, but the leach rate of silicon appears not to be affected by how frequently the solution is changed; see Figures $18(\mathrm{a})$ and $18(\mathrm{c})$. Leach rates decrease as solutions are changed less frequently. It is particularly important that the actinides as a class are leached at rates below that of the silica matrix, which means they are effectively being left behind in a chemical/physical form yet to be defined. As discussed earlier, postleach surface characterization is just beginning; after 2 years at $25^{\circ} \mathrm{C}$ no gel layer or residual heavy metal film has been optically detected.

- For all actinides studied, sodium bicarbonate solution gives the highest releases; and, in general, deionized water or WIPP B brine gives the lowest values of release. For plutonium and neptunium, WIPP B brine gives the lowest releases while curium, uranium, and americium are lowest in deionized water; see Figure $18(b)$.

- For all solutions except $\mathrm{CaCl}_{2}$, neptunium shows the highest actinide release rate; and, in general, curium or uranium shows the lowest releases. Uranium shows 


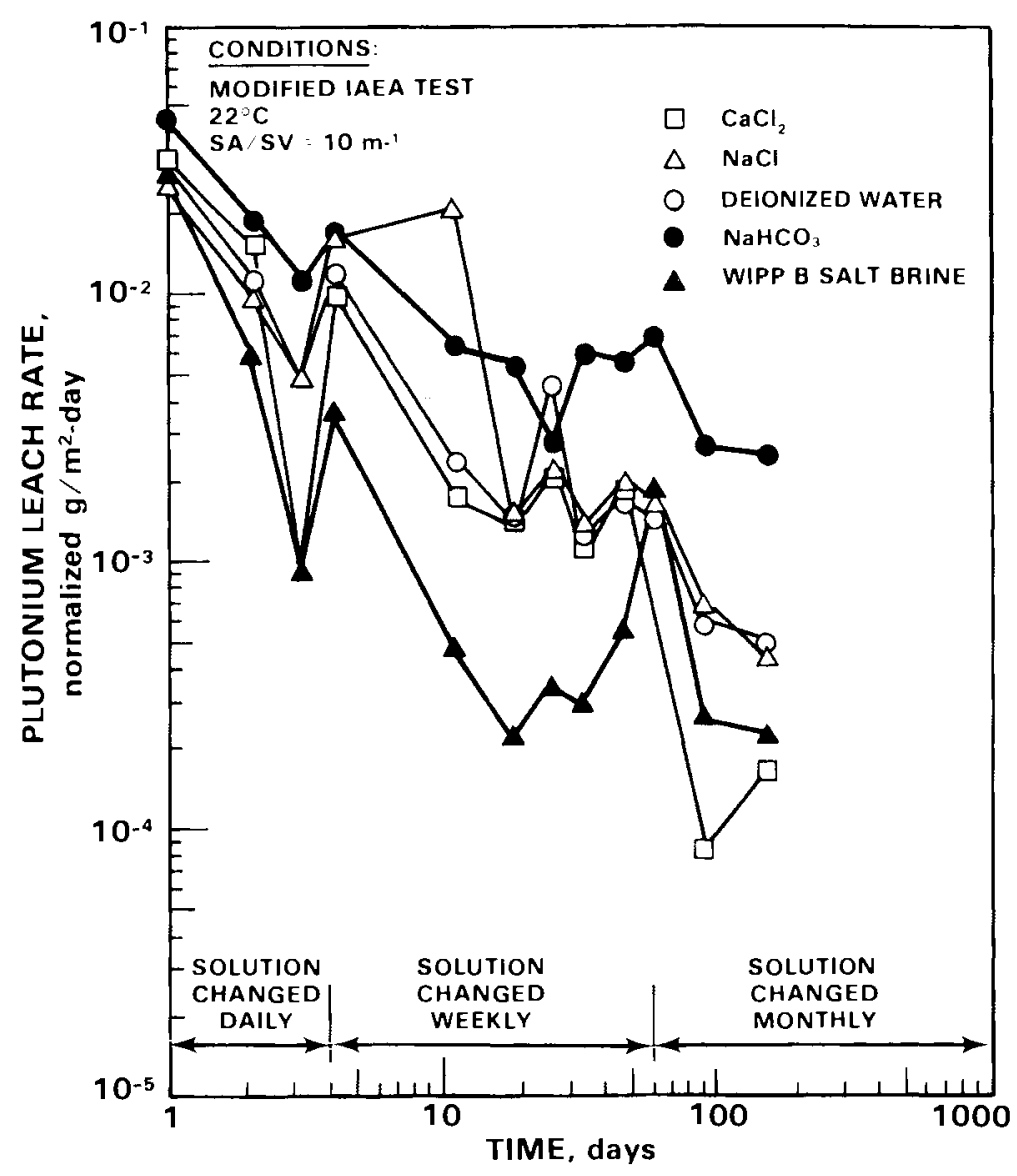

(a) Leach Rate Curves

FIGURE 18. Leaching of Actinide-Doped Glass in Five Solutions

Glass 76-68 beads were doped with actinides at levels expected to be present in waste glass. Leaching was performed in five solutions using the modified IAEA test.

Incremental plutonium leach rates in the different solutions are apparently influenced when the solution-changing frequency is decreased. These changes, at 3 days and again at 60 days, are reflected by peaks in the leach rate curves. Rates decrease rapidly in the first 1-3 days and are discontinuous with the shift in solution-changing frequency but continue to drop from 5 through 20 days. This early rapid rate decrease probably reflects the formation of a depleted ge 1 layer on the glass surface. From about 20 through 60 days, leach rates apparently increase, which is unexpected. The range of leach rates for the five solution types is one order of magnitude.

a high release rate in $\mathrm{NaHCO}_{3}$, which may be due to the known affinity for uranium to form soluble carbonate complexes (Grandstaff 1976). Curium displays a high release rate in $\mathrm{CaCl}_{2}$ and deionized water leach solutions, while americium has the highest of the actinide release rates in $\mathrm{CaCl}_{2}$ solution. 


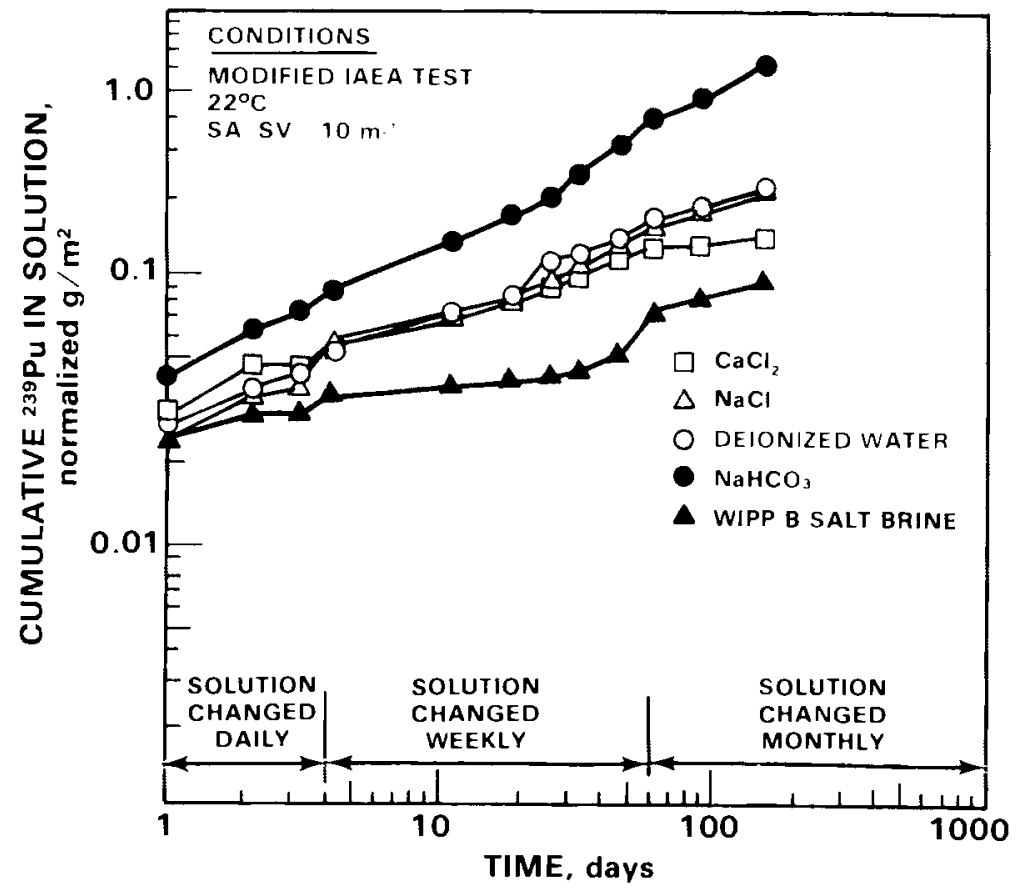

(b) Cumulative Plutonium in Solution Versus Time

FIGURE 18. (Contd)

For plutonium and other actinides sodium bicarbonate solution yields the highest releases; and deionized water or WIPP B salt brine generally results in the lowest releases.

- The release mechanism for actinides is dependent upon leach solution composition, see Figure 18(b); the trend with increasing leaching time is toward larger differences between leach solutions.

- For a particular leach solution, actinide element release appears to be approaching a common mechanism at extended leach times. As Figure $18(\mathrm{c})$ shows, act inide releases tend toward convergence when leached from the same solution.

Results using the modified IAEA procedure have been related to continuous flow tests (Weed et al. 1979). Previous studies and the present work all show indications that the frequency of changing solutions has a direct effect on the apparent leach rate. The cumulative release curves for neptunium and plutonium depicted in Figure 18(b), for example, indicate that apparent rate changes correspond to the frequency of solution changes (daily, weekly, or monthly). These changes are in the direction of decreasing leach rate with decreasing rate of solution exchange. Static and continuous flow leach tests are in progress to clarify this issue. 


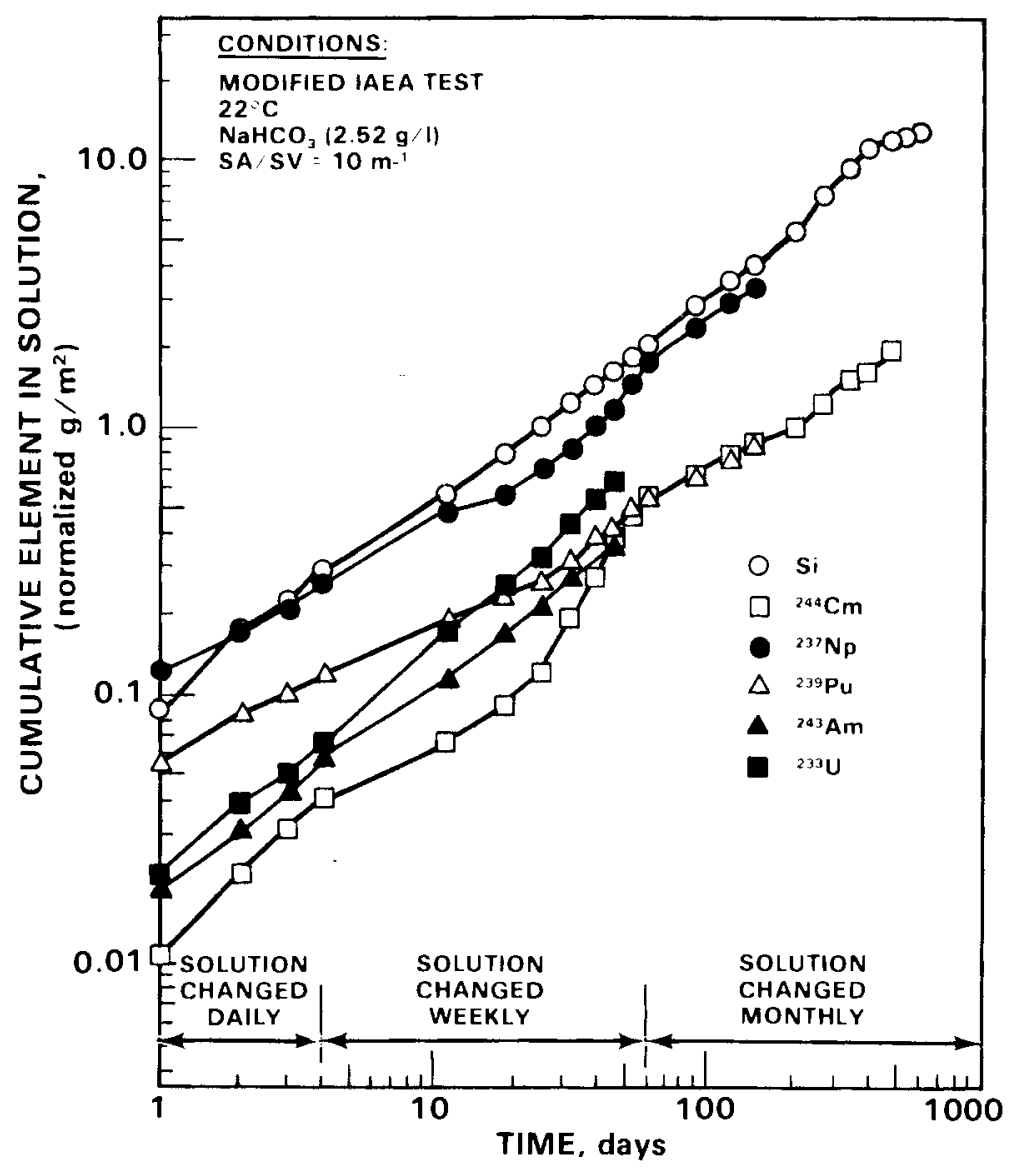

(c) Elemental Releases of Sodium Bicarbonate Solution

FIGURE 18. (Contd)

Actinide release rates are generally lower than those for silicon, and neptunium leaches at a rate comparable to silicon. It is significant that actinides as a class leach more slowly than silicon--the major glass network former. Act inides probably remain in the depleted gel layer as relatively insoluble hydroxides in the same way rare earth elements and iron behave in nonradioactive studies of this glass.

Leaching of doped glass beads has also been conducted at elevated temperatures in different leachant solutions (Westsik and Harvey 1980). The 76-68 glass beads leached in deionized water, WIPP B salt brine, and $2.52 \mathrm{~g} / 1$ sodium bicarbonate solution had been doped with tracer quantities of ${ }^{99} \mathrm{Tc},{ }^{233} \mathrm{U},{ }^{237} \mathrm{~Np},{ }^{239} \mathrm{Pu},{ }^{243} \mathrm{Am}$, and ${ }^{244} \mathrm{Cm}$. Figure 19 shows releases of these isotopes into deionized water at $150^{\circ} \mathrm{C}$. The amount of material released includes both that in solution and that which plated out on the leach container walls. The leachates were also analyzed for nonradioactive glass components. Most elements in this study were found in higher concentrations in salt brine than in either deionized water or 


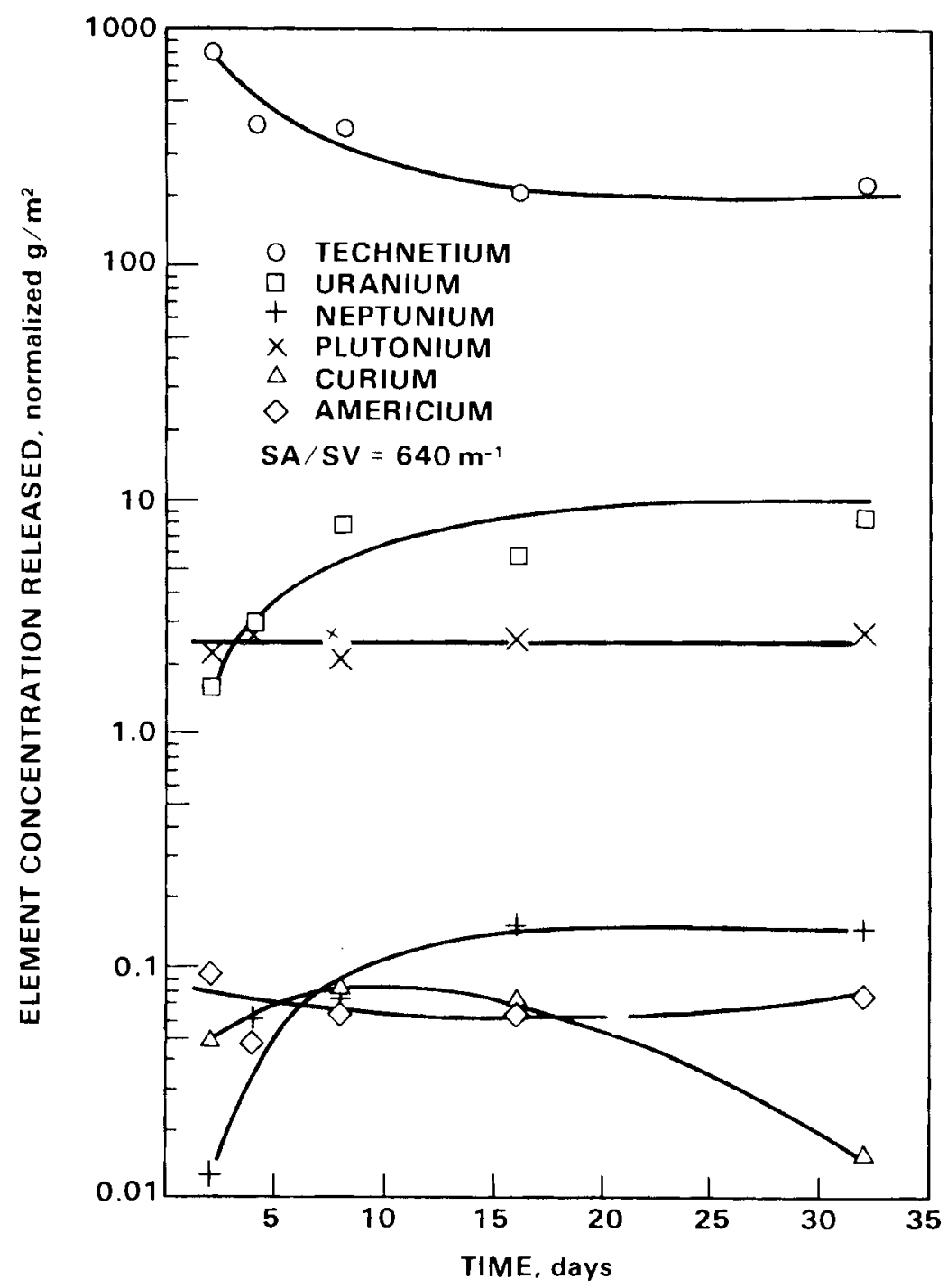

FIGURE 19. Actinide and Technetium Releases from Glass 76-68 Leached in $150^{\circ} \mathrm{C}$ Deionized Water

Deionized water, WIPP B salt brine, and a sodium bicarbonate solution were used as leachants in a study of high-temperature leaching of glass 76-68. Total quantities of 99 Tc, ${ }^{23} 3_{\mathrm{J},}{ }^{33} \mathrm{~Np}, 239 \mathrm{Pu}, 243 \mathrm{Am}$, and $244 \mathrm{Cm}$ that were released to deionized water at $150^{\circ} \mathrm{C}$ are shown. Solubility and solution composition significantly impact the results of this test. For example, most of the total amount of each actinide released was found plated out on the leach container walls rather than in solution.

the bicarbonate solution. Silicon, boron, molybdenum, and the actinides do not follow this trend. Solubilities, pH, back reactions, and the formation of glass alteration products all affect element release from the glass to the solution. 
In April 1970 a canister of borosilicate waste glass was produced as part of the Waste Solidification Engineering Prototype Program (WSEP). Since that date the canister has been periodically core drilled, and the glass samples obtained have been characterized (Mendel 1977). The latest sampling occurred in April 1978, and several leach tests were started about 6 months thereafter.

Previously, the glass samples had been leached in a Paige apparatus containing deionized water at ambient hot cell temperature. The 8-year-old samples were leached in this system, but they were also leached by the modified IAEA and ISO leach test methods. Release rates were calculated from cesium concentrations in the leachate (Mendel et al. 1977).

Results of the Paige leach test indicated that the glass retained its durability despite the temperatures and radiation to which it had been exposed. Furthermore, a sample of the glass that was remelted and then leached showed no change in its apparent leachability. Comparing the results obtained by the Paige, IAEA, and ISO procedures revealed that the test method does influence the apparent leach rate; Figure 20 shows the results obtained by each method. The IAEA test used 2 grams of $-40+60$ mesh glass in $500 \mathrm{ml}$ of water. Ross et al. (1978) reported that powder samples typically exhibit lower leach rates than monolithic samples of the same material when normalized for geometric surface area. Similar trends were observed in these experiments. Both the ISO and Paige test used monolithic samples; however, the Paige samples were exposed to more solution per unit of sample surface area than the ISO samples, which could cause the leach rates obtained by the Paige method to be higher.

\section{COMPARISON OF WASTE FORMS}

It is important to evaluate different waste forms under the same conditions to determine if one is clearly superior. There have been many glasses developed to encapsulate waste and many versions of crystalline products have been proposed. Two of the forerunners of the crystalline waste encapsulants are a silicate-based supercalcine and a titanate-based synroc.

In an effort to compare the waste form types, simulated waste glasses $72-68,77-107$, and 77-260, supercalcine SPC-4, and synroc-B were leached under identical conditions to compare their behavior in hydrothermal environments. Each was leached in $100 \mathrm{ml}$ of deionized water $\left(S A / S V=6-8 \mathrm{~m}^{-1}\right.$ ) at temperatures of $25,50,100,150,250$, and $350^{\circ} \mathrm{C}$. The resulting leachates were analyzed and each waste form was examined metallographically. Figures 21(a) and $21(b)$ show Arrhenius plots of the elemental releases from glass 77-260, supercalcine, and synroc. Only CS, Mo, Si, and Al are shown for clarity; a more complete analysis and experimental description are given elsewhere (Westsik, Shade, and McVay 1979). Since synroc was not evaluated at lower temperatures, a complete comparison is not possible. However, synroc shows somewhat better leach resistance at temperatures above $250^{\circ} \mathrm{C}$ but approaches the other waste forms (perhaps with even more elemental release) at temperatures below $250^{\circ} \mathrm{C}$. The silicate-based waste forms--glass and supercalcine--behave similarly over most of the temperature range investigated. With the limited amount of data available, one can conclude that there are no major differences in the waste forms. 


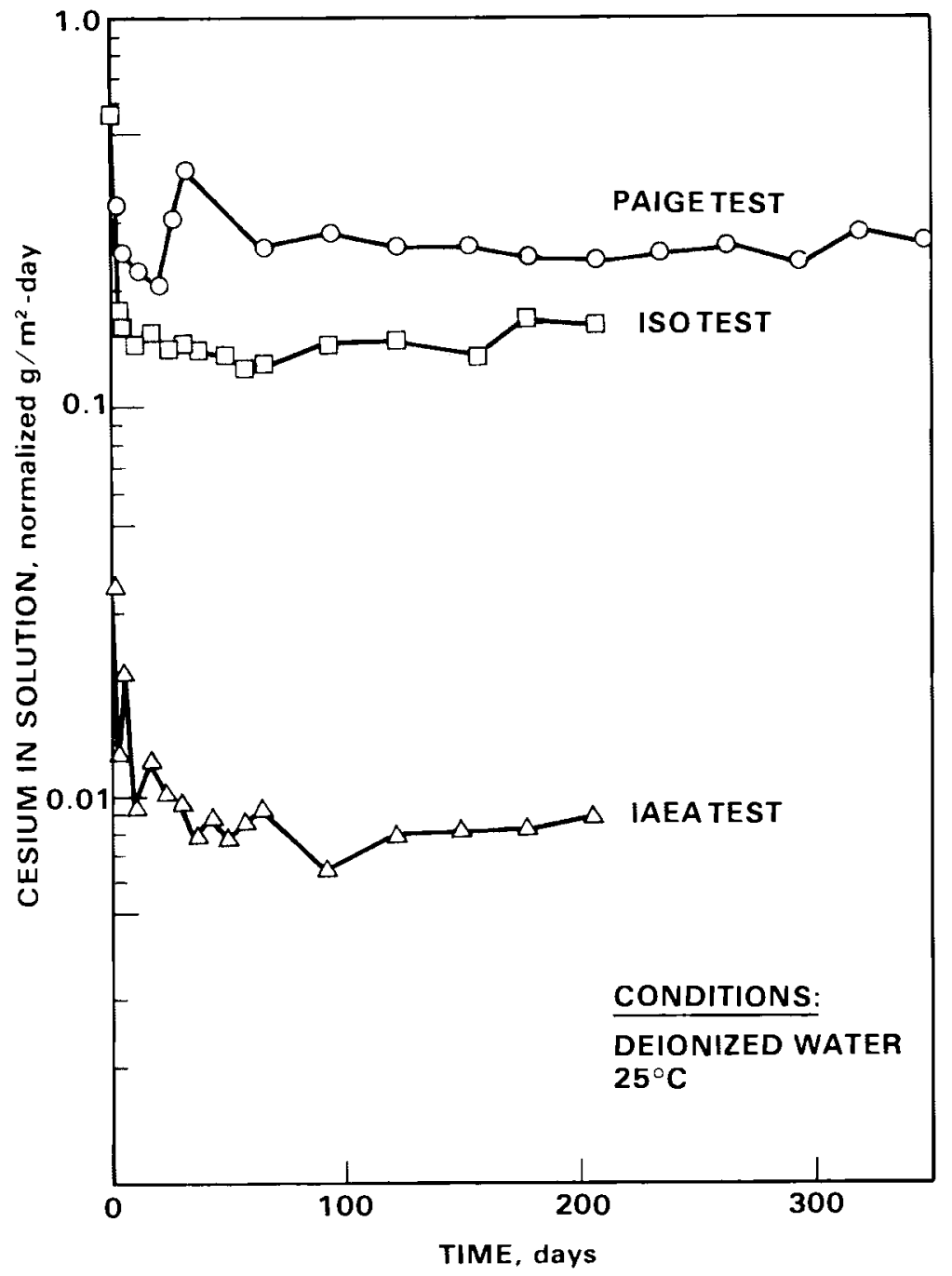

FIGURE 20. Comparison of Three Leaching Techniques on 8-Year-01d Radioactive Waste Glass

Glass in the SS-12 canister (fully radioactive glass produced 8 years ago) was leach tested to compare 1) the durability of the glass after 8 years of storage with its durability when it was first prepared and 2) the results of different long-term leach tests on the same glass. Leach rates from the ISO and Paige tests (using one and several large chunks of sample, respectively) are similar; while rates from the IAEA test (using $-42+60$ mesh crushed samples) are at least an order of magnitude lower.

Samples that were collected earlier (11 months and 33 months after pouring) were leach tested by the Paige test for up to 60 days. Leach rates were within experimental error of the rates shown for the recent 8 -year-old sample. Thus, it can be concluded that the chemical durability of the glass has not deteriorated with storage. 


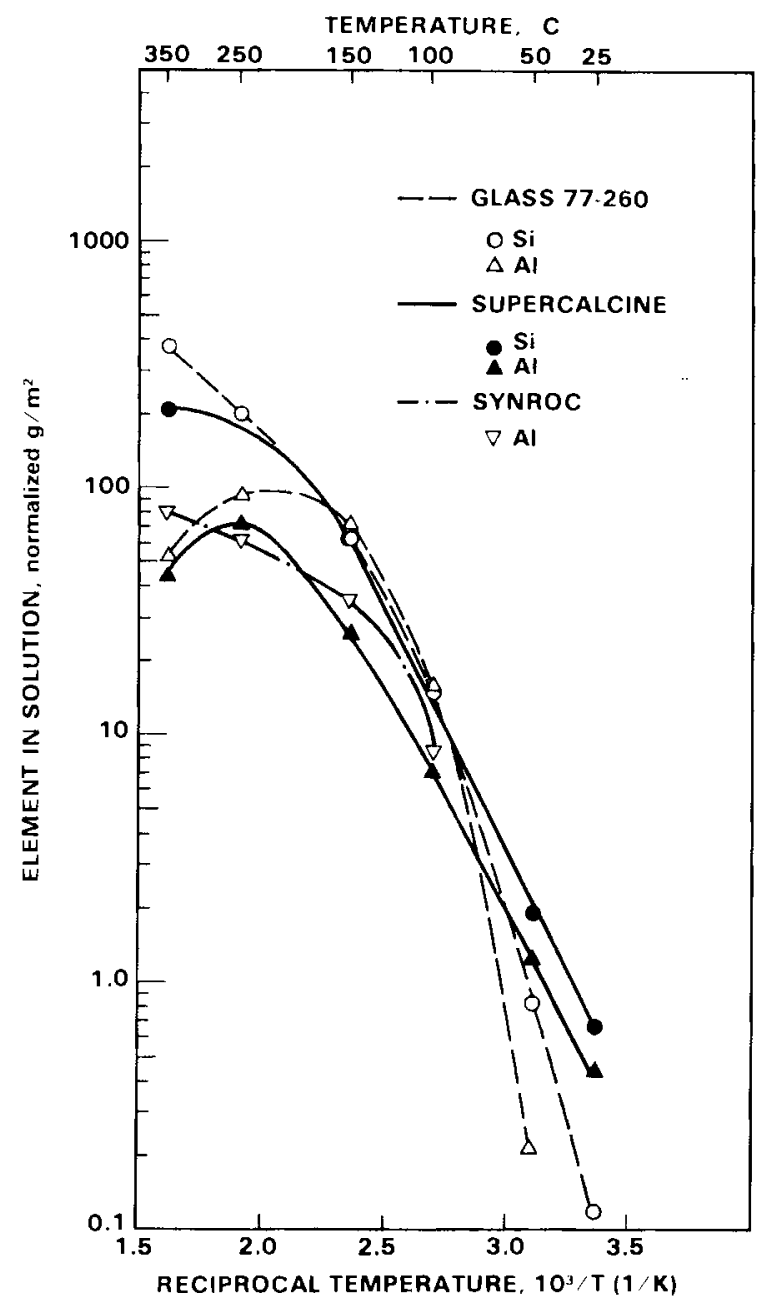

(a) Aluminum and Silicon Releases

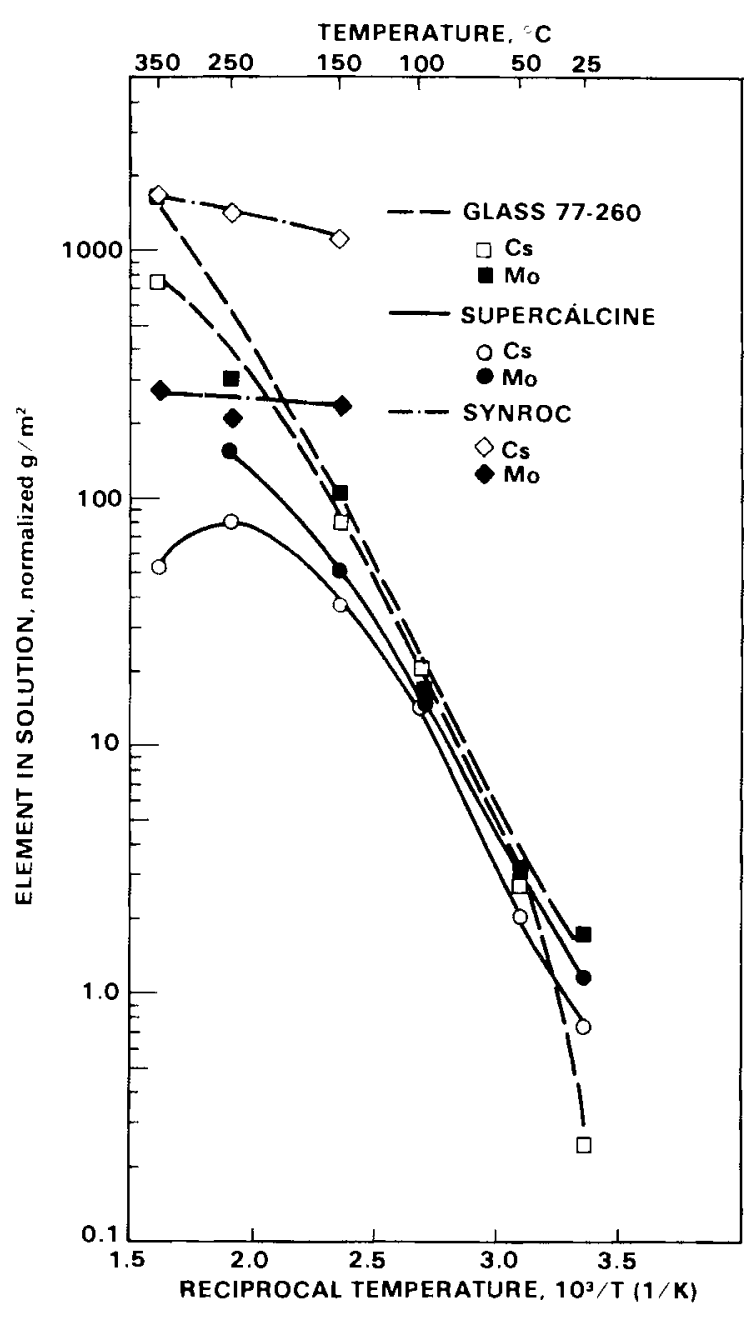

(b) Cesium and Molybdenum Releases

FIGURE 21. Leaching of Glass, Supercalcine, and Synroc as a Function of Temperature

Samples of glass 77-260, supercalcine SPC-4, and synroc-B were leached in deionized water for 3 days at temperatures ranging from 25 to $350^{\circ} \mathrm{C}$. Sample SA/SV ratios varied slightly (from 6 to $8 \mathrm{~m}^{-1}$ ). Aluminum and silicon releases and cesium and molybdenum releases are shown in Figures (a) and (b), respectively.

The temperature dependence below $150^{\circ} \mathrm{C}$ for both glass and supercalcine is roughly linear on these Arrhenfus plots. The synroc was not tested in the lower temperature range; however, the aluminum release for synroc may behave similarly to glass and supercalcine throughout the lower temperature range. Reductions or reversals in temperature dependence at high temperature may be due to either plating out of the measured elements on the leach vessel walls or hydrothermal reactions forming more stable crystalline phases in the waste form. The main conclusion to be drawn is that the three materials show no apparent major differences in leaching behavior. 
Spent light water reactor (LWR) fuels have been leach tested to determine the effect of different generic ground waters on the chemical durability of the fuel. These tests originated in the Waste Isolation Safety Assessment Program in 1977 and are now being funded by the WRIT program. This work is reported in detail in PNL-3173 (Katayama, Bradley, and Harvey 1980).

Spent fuel with a burnup of $2417 \mathrm{GJ} / \mathrm{kgU}$ was leach tested in five leach solutions: deionized water, 0.03-M sodium chloride, saturated WIPP B brine, 0.015-M calcium chloride, and 0.03-M sodium bicarbonate. A modified IAEA leach test was used at ambient hot cell temperature (about $25^{\circ} \mathrm{C}$ ).

The leach rates shown in Figure 22 for deionized water are typical of those calculated. There is a spread in the leach rate curves for the radioisotopes analyzed, and the general trend is toward decreased leach rates with time. Table 8 compares the elemental leach rates for each solution type after 467 days of leaching; there is no ordered trend. Table 9 compares the effect of solution type on each radionuclide measured. There is an apparent trend where deionized water produces the highest leach rates and calcium chloride produces the lowest rate for six elements and the second lowest rate for the other three elements.

Organic waste forms have several advantages including low-temperature forming processes and the ability to incorporate many waste types and compositions. Organics may also be advantageous in dealing with TRU ashes when self-heating is not present. The chemical durabilities of a number of organics and one cement waste form containing TRU ash were measured in the WRIT program. The experimental program conducted at Brookhaven National Laboratory (BNL) will determine the leaching properties of TRU-contaminated incinerator ash waste forms using hydraulic cement, urea-formaldehyde, bitumen, and polyester-styrene as solidification agents.

The IAEA leaching test was used to produce the incremental leach rate data shown in Figure 23. It can be seen that the polyester-styrene waste form shows small differences between the leach solutions studied (except for WIPP B leach solution) while cement and urea-formaldehyde waste forms showed up to 1.5 orders of magnitude difference in plutonium release. WIPP $B$ brine shows the lowest release in all cases after 30 days of leaching. The polyester-styrene and concrete waste forms show from two to three orders of magnitude lower plutonium release than urea-formaldehyde. The release rate of plutonium from cement or polyester-styrene shows approximately two orders of magnitude lower leach rates than plutonium-doped 76-68 simulated waste glass (Bradley 1979) using the same leach method, temperature, sampling times, and solutions.

\section{WASTE PACKAGE LEACHING}

When an aqueous solution interacts with a waste form, complex phenomena occur. A large effort in the WRIT program has gone into understanding these phenomena with some success. However, when other constituents are introduced into the system (such as rock, canister, backfill, and overpack materials), the complexity increases many fold. 


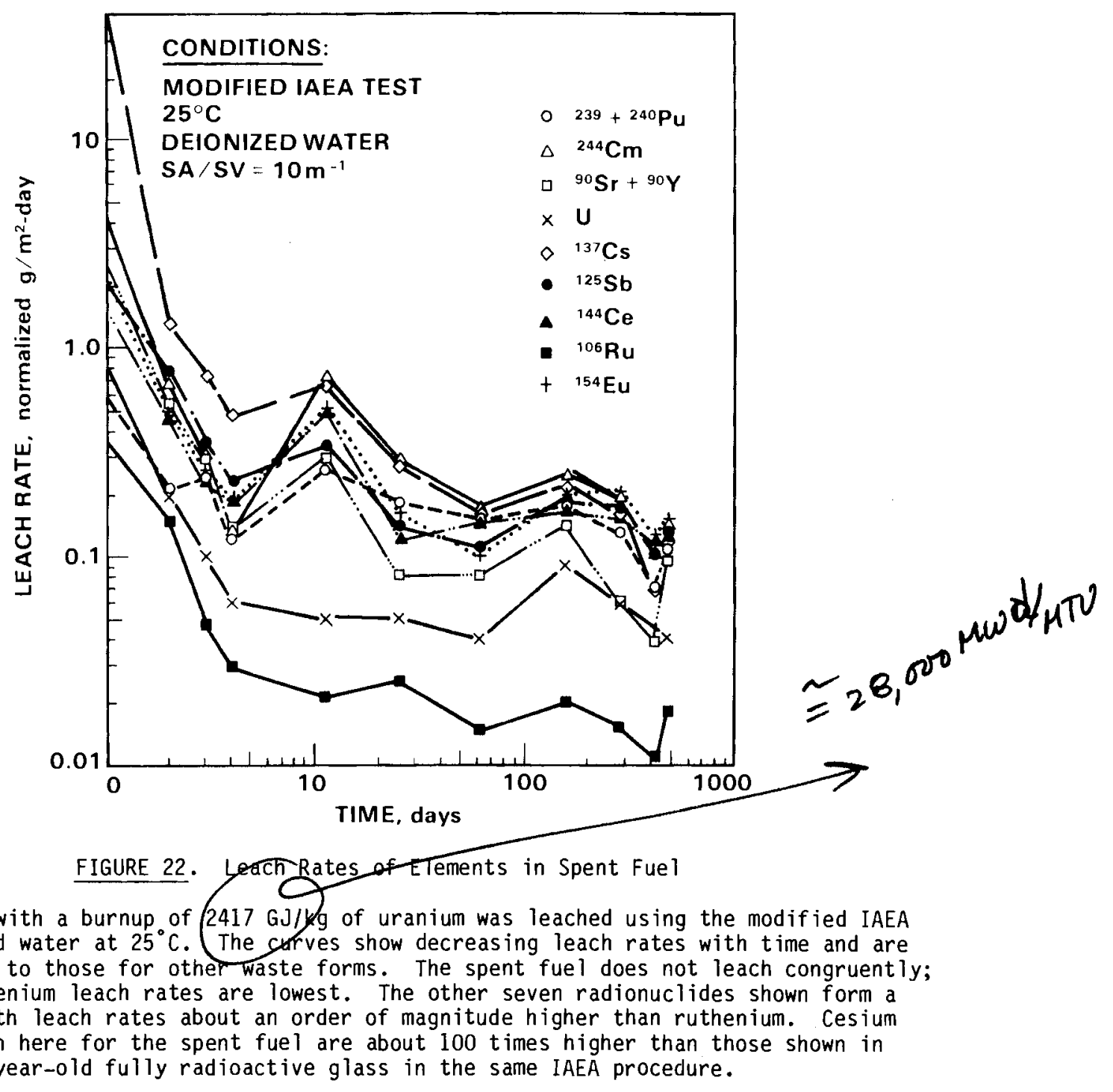

The long-range purpose of the waste package tests is to provide near-field source-term data and predictive release models emphasizing water-soluble actinide and fission product concentrations that might be generated under various postemplacement repository accident scenarios.

The objectives of the present effort are two-fold: 1) to develop a capability for conducting waste package systems tests using integrated repository components including fully radioactive waste forms such as glass and spent fuel and 2) to conduct exploratory studies in existing autoclave or digestion bomb facilities using sealed components and $\mathrm{UO}_{2}$-doped 76-68 waste reference glass to identify areas requiring further effort. 
TABLE 8. Comparison of Incremental Leach Rates of Elements for Each Solution Type

\begin{tabular}{ll} 
SOLUTION & $\begin{array}{l}\text { OBSERVED RANKING OF ELEMENT } \\
\text { FROM HIGHEST TO LOWEST (467 DAY }\end{array}$ \\
\hline DEIONIZED WATER (DIW) & Eu, Cm, Sb, Ce, Cs, Pu, Sr+Y, U, Ru \\
WIPP B SALT BRINE & Cs, Sb, Pu, Sr+Y, Cm, Eu, Ce, U, Ru \\
$\mathrm{NaHCO}_{3}$ & Sb, Cs, U, S r + Y, Pu, Cm, Ru, Eu, Ce \\
$\mathrm{NaCl}$ & Cs, Eu, Cm, Ce, Sb, Pu, Sr+Y, U, Ru \\
$\mathrm{CaCl}_{2}$ & Cs, Ru, Pu, Sr+Y, Eu, Ce, Cm, Sb, U
\end{tabular}

TABLE 9. Results of the Effects of Solution Type on Each Element

\begin{tabular}{|c|c|}
\hline ELEMENT & $\begin{array}{l}\text { OBSERVED RANKING OF SOLUTIONS } \\
\text { FROM HIGHEST TO LOWEST ELEMENT } \\
\text { RELEASE (467 DAYS) }\end{array}$ \\
\hline URANIUM & $\mathrm{DIW}, \mathrm{NaHCO}_{3}, \mathrm{NaCl}, \mathrm{WIPP}, \mathrm{CaCl}_{2}$ \\
\hline${ }^{137} \mathrm{Cs}$ & DIW, $\mathrm{NaCl}$, WIPP, $\mathrm{NaHCO}_{3}, \mathrm{CaCl}_{2}$ \\
\hline${ }^{144} \mathrm{Ce}$ & DIW, $\mathrm{NaCl}$, WIPP, $\mathrm{CaCl}_{2}, \mathrm{NaHCO}_{3}$ \\
\hline $240+239 \mathrm{Pu}$ & DIW, WIPP, $\mathrm{NaCl}, \mathrm{NaHCO}_{3}, \mathrm{CaCl}_{2}$ \\
\hline${ }^{244} \mathrm{Cm}$ & DIW. $\mathrm{NaCl}$, WIPP, $\mathrm{NaHCO}_{3}, \mathrm{CaCl}_{2}$ \\
\hline${ }^{90} S r+{ }^{90} y$ & DIW, $\mathrm{NaCl}$, WIPP, $\mathrm{NaHCO}_{3}, \mathrm{CaCl}_{2}$ \\
\hline${ }^{154} \mathrm{Eu}$ & DIW, $\mathrm{NaCl}$, WIPP, $\mathrm{CaCl}_{2}, \mathrm{NaHCO}_{3}$ \\
\hline${ }^{125} \mathrm{Sb}$ & DIW, $\mathrm{NaHCO}_{3}$, WIPP, $\mathrm{NaCl}, \mathrm{CaCl}_{2}$ \\
\hline${ }^{106} \mathrm{Ru}$ & DIW, $\mathrm{NaCl}, \mathrm{WIPP}, \mathrm{CaCl}_{2}, \mathrm{NaHCO}_{3}$ \\
\hline
\end{tabular}

Table 10 presents some initial results for a salt-bearing waste package test. Comparison of the initial brine composition with that obtained after quenching a 30-day run from $250^{\circ} \mathrm{C}$ illustrates both a repartitioning of elements during salt recrystallization and transition element mobilization through possible chloride complexing. Salt recrystallization occurs during quenching as a result of decreasing salt saturation from $250^{\circ} \mathrm{C}$ to ambient temperatures. Consequently, the least soluble elements (such as $\mathrm{Ca}$ and $\mathrm{Sr}$ ) tend to reprecipitate while more soluble elements (such as $\mathrm{Cs}, \mathrm{K}$, and $\mathrm{Mo}$ ) tend to remain in the liquid phase. Furthermore, those elements such as $\mathrm{Zn}, \mathrm{Pb}, \mathrm{Fe}$, and $\mathrm{Ni}$ whose primary source is the glass or canister material tend to build up in the aqueous phase presumably through chloride complexing.

Preliminary results from another waste package test, see Figure 24, show the surface of a rock wafer that was in contact with the surface of a $U 0_{2}$-doped 76-68 glass minicanister. 


\section{LEGEND FOR LEACH TEST CURVES}

\begin{tabular}{|c|c|c|}
\hline CURVE NO. & SYMBOL & LEACHANT \\
\hline 1 & $\longrightarrow$ & DEMINERALIZED WATER \\
\hline 2 & $-\square$ & WIPP BRINE "B" \\
\hline 3 & $\cdots \cdots \Delta$ & $\begin{array}{l}\text { SODIUM-DOMINATED } \\
\text { GROUNDWATER }\end{array}$ \\
\hline 4 & $\cdot \rightarrow$ & $\begin{array}{l}\text { CALCIUM-DOMINATED } \\
\text { GROUNDWATER }\end{array}$ \\
\hline 5 & . & $\begin{array}{l}\text { BICARBONATE-DOMINATED } \\
\text { GROUNDWATER }\end{array}$ \\
\hline
\end{tabular}
MODIFIED IAEA TEST
$25^{\circ} \mathrm{C}$
SA $/$ SV $=10 \mathrm{~m}-1$

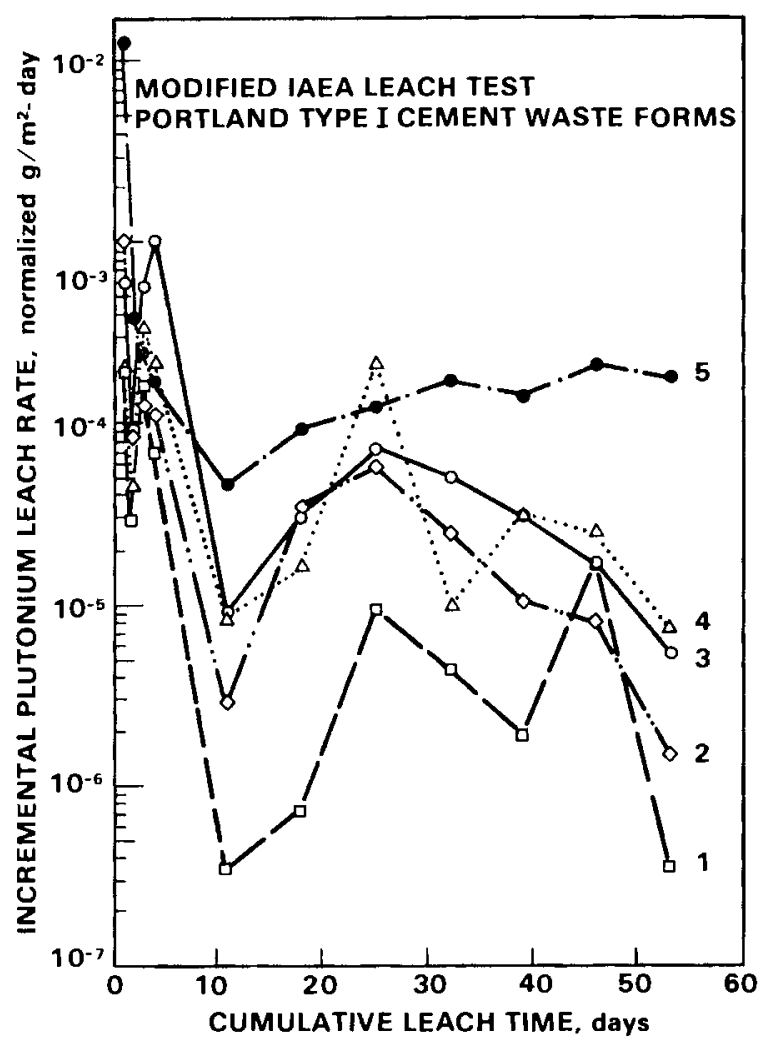

(a) Leach Rates of Portland Type I Cement

FIGURE 23. Leaching of Plutonium from Three TRU Ash Waste Forms in Five Leachants

Plutonium containing TRU waste ash was incorporated in three host materials: Portland Type I cement, urea-formaldehyde resin, and polyester-styrene. Samples of each form were leached using a modified IAEA test (leachant changed periodically) at $25^{\circ} \mathrm{C}$. The Portland cement and polyester-styrene samples permit two to three orders of magnitude less plutonium release than the urea-formaldehyde waste form. Leach solution composition produced the largest leach rate variation for the urea-formaldehyde form and the least variation for the polyester-styrene form. WIPP B salt brine consistently resulted in the lowest leach rates. Plutonium leach rates and waste loadings for polyester-styrene and cement TRU waste forms are 100 times lower than those for borosilicate glass. 


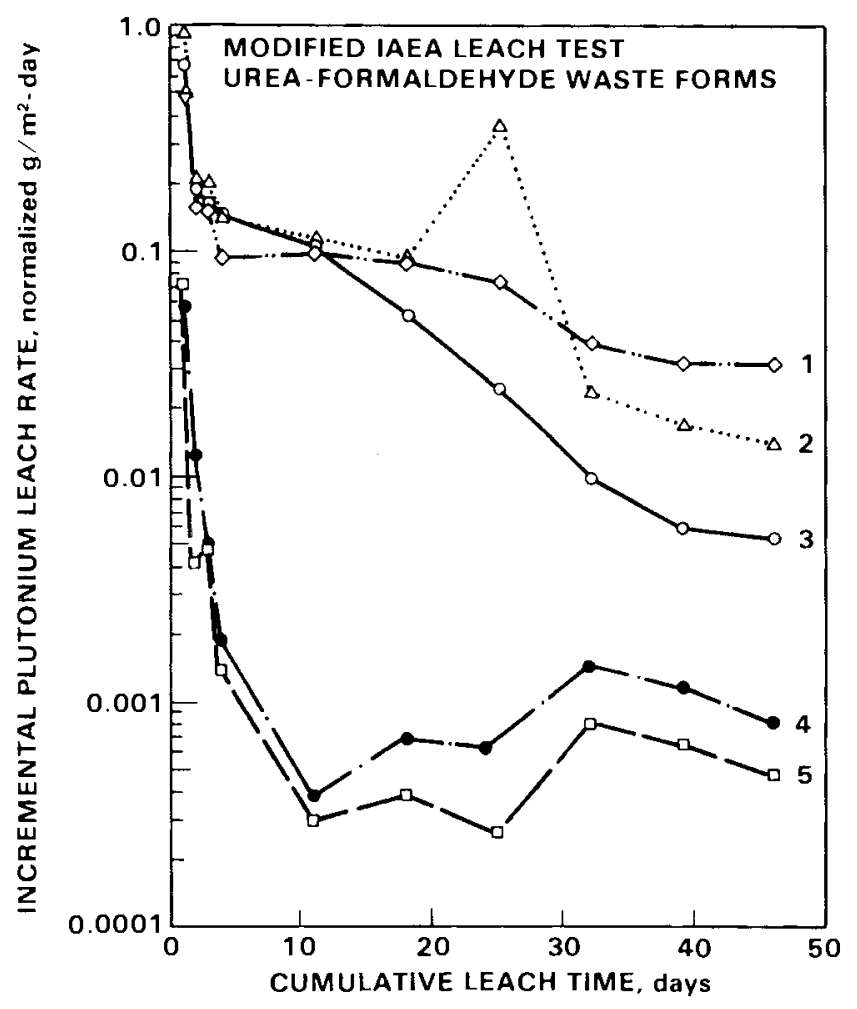

(b) Leach Rates of Urea-Formaldehyde

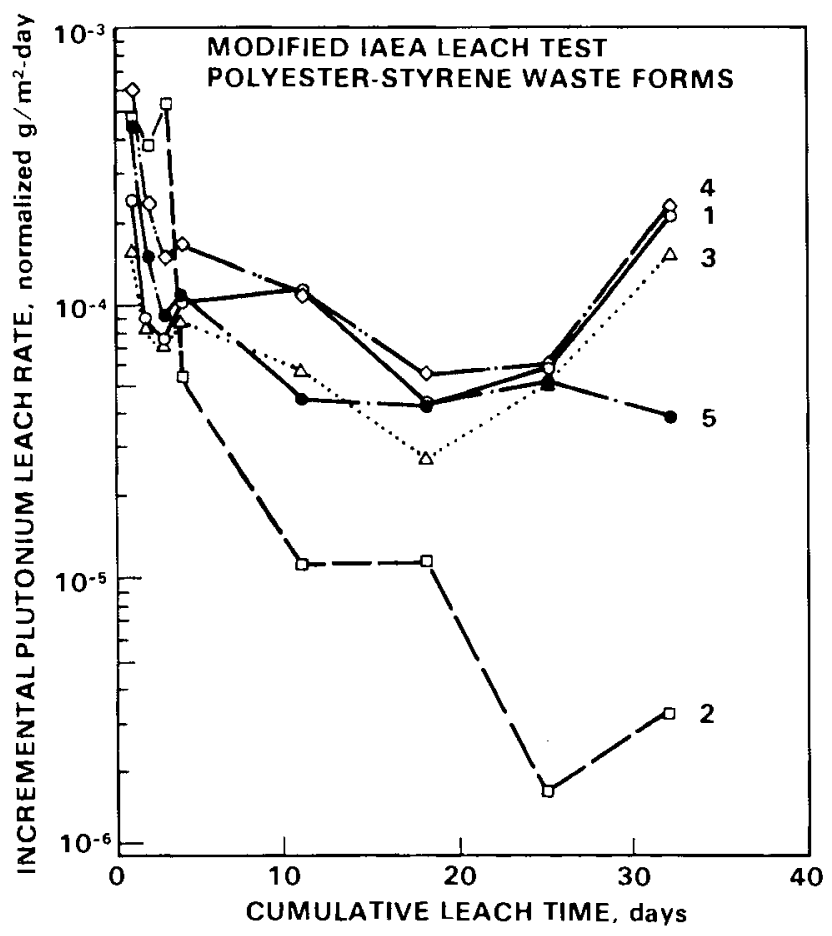

(c) Leach Rates of Polyester-Styrene

FIGURE 23. contd 
TABLE 10. Brine Composition from Waste Package Tests

\begin{tabular}{|c|c|c|}
\hline ELEMENT & $\begin{array}{l}\text { INITIAL BRINE } \\
\text { COMPOSITION, } \\
\mu \mathrm{g} / \mathrm{ml}\end{array}$ & $\begin{array}{l}\text { COMPOSITION AFTER } \\
250^{\circ} \mathrm{C} \text { FOR } 30 \text { DAYS, } \\
\mu \mathrm{g} / \mathrm{ml}\end{array}$ \\
\hline$\overline{\mathrm{Al}}$ & DL(a) & 3.3 \\
\hline B & 2.0 & 73.9 \\
\hline $\mathrm{Ba}$ & 0.3 & 1.9 \\
\hline $\mathrm{Ca}$ & 905.5 & 156.6 \\
\hline $\mathrm{Ce}$ & 1.6 & 2.8 \\
\hline Co & DL & 1.1 \\
\hline $\mathrm{Cr}$ & $\mathrm{DL}$ & 1.2 \\
\hline $\mathrm{Cu}$ & 0.18 & 2.5 \\
\hline Dy & 0.16 & 0.9 \\
\hline $\mathrm{Fe}$ & $\mathrm{DL}$ & 6.0 \\
\hline Gd & 0.74 & 1.6 \\
\hline $\mathrm{K}$ & 1,383 & 11,910 \\
\hline La & 9.29 & 1.14 \\
\hline $\mathbf{L i}$ & 0.60 & 0.71 \\
\hline $\mathbf{M g}$ & 481 & 4,084 \\
\hline $\mathrm{Mn}$ & DL & 5.2 \\
\hline Mo & $\mathrm{DL}$ & 2.0 \\
\hline $\mathrm{Na}$ & 82,450 & 87,050 \\
\hline $\mathrm{Ni}$ & DL & 11.8 \\
\hline $\mathbf{P}$ & DL & 11.4 \\
\hline $\mathrm{Pb}$ & 1.05 & 10.6 \\
\hline Ru & 0.69 & 3.19 \\
\hline sb & $\mathrm{DL}$ & 3.6 \\
\hline Si & 1.84 & 19.63 \\
\hline Sr & 24.6 & 12.8 \\
\hline Te & DL & 7.8 \\
\hline $\mathbf{Z n}$ & DL & 29.5 \\
\hline Cs & 0.93 & 16.0 \\
\hline
\end{tabular}

Brine composition before and after a $250^{\circ} \mathrm{C}, 30$-day waste package test is shown. During cool-down the salt recrystallizes leading to a repartitioning of elements between the solid and solution phases. The more soluble brine constituents, such as $\mathrm{Mg}$, tend to become concentrated in the solution phase while the least soluble, such as $C a$, are concentrated in the solid phase. Elements such as the transition series elements, which tend to form aqueous chloride complexes, become enriched in the solution phase. The primary sources for these elements are the stainless steel canister and glass 76-68.

The iron staining on the wafer resulted from apparent oxidizing conditions that occurred when a slow leak developed in the autoclave, exposing the waste package to the vapor phase. An ESCA scan of this surface indicated that uranium had diffused from the glass into the rock wafer, and an SEM study of the glass surface showed U-rich gel-like beads and Zn silicates as alteration products. Other runs in which the waste package remained submerged and presumably relatively reduced showed no uranium mobilization. These results are compatible with the concept of increased $\mathrm{U}^{+6}$ mobility relative to $\mathrm{U}^{+4}$. 


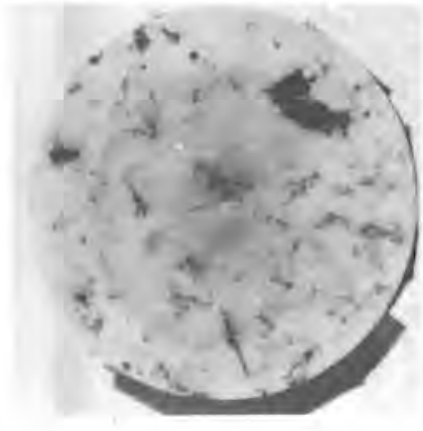

(a) Granite Wafer

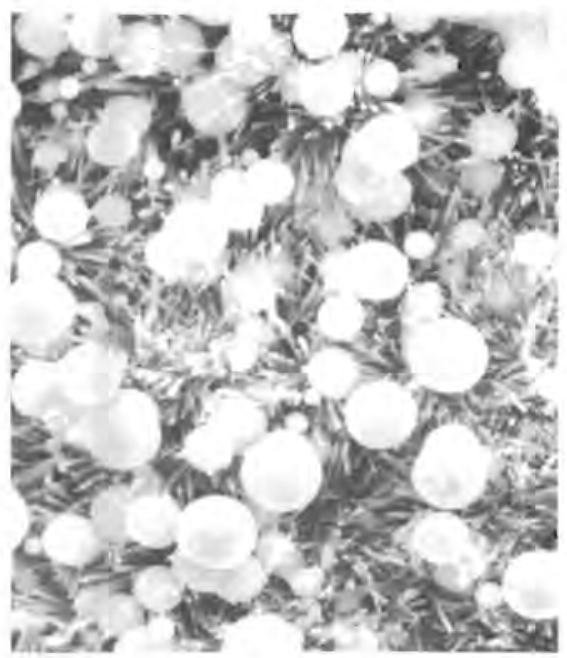

$10^{4} \mathrm{~nm}$

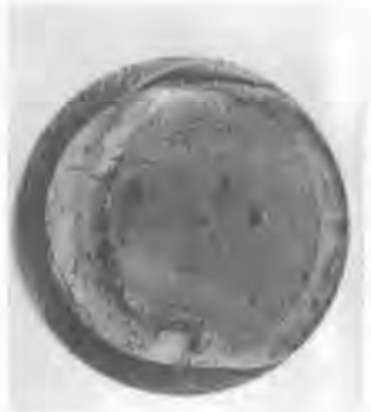

(b) Glass Surface of Minicanister

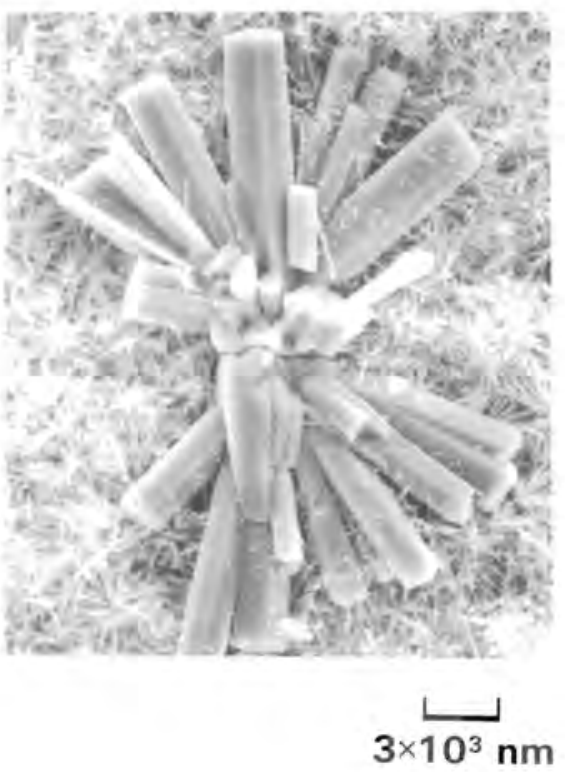

(d) $\mathrm{Zn}_{2} \mathrm{SiO}_{4}$ (Willemite) Crystals

(c) U-Rich "Gel-Like" Beads

FIGURE 24. Waste Package Leaching Test

The surface of a granite rock wafer was placed in contact with the surface of a $\mathrm{UO}_{2}-$ doped 76-68 glass-filled minicanister. The combined sample was leached for 30 days at $200^{\circ} \mathrm{C}$ in deionized water. Staining resulted from apparent oxidizing conditions that may have developed during a slow leak in the autoclave. Electron sputtering chemical analysis (ESCA) profiles indicated that both zinc and uranium (presumably $\mathrm{U}^{+6}$ ) diffused from the glass into the rock wafer.

The spheres in the scanning electron microscope (SEM) micrographs of the glass surface are primarily uranium. The large crystalline rosette is $\mathrm{Zn}_{2} \mathrm{SiO}_{4}$ (possibly the mineral Willemite), and the small needle-like crystals are a Ca-Fe phosphate. These alterations were not observed in waste package tests where the package was completely submerged in water during the run and presumably was in a relatively reducing environment. 


\section{PHASE BEHAVIOR AND THERMAL EFFECTS}

Important properties of nuclear waste solids such as chemical durability and stability to radiation damage are affected by the composition and concentration of phases present on a microscale in the waste materials. Nuclear waste glasses as well as crystalline waste forms can have complex phase structures depending upon composition, thermal history, and redox conditions. In order to understand and predict the behavior of nuclear waste solids in the range of possible storage conditions, it is necessary to investigate their phase morphologies.

Limited phase characterization is performed as part of most of the studies reported in other sections of this document. More detailed examination is undertaken to investigate optimum preparation procedures, long-term self-heating effects, and effects of accident scenarios.

Because nuclear waste glasses have been under study longer than alternative crystaliine waste forms and because of the difficulty of analyzing micron-size crystallites in crystalline waste forms, much more phase behavior information is available for glass than for crystalline waste forms. Past work at PNL has concentrated mainly on phases produced in glasses for commercial reactor waste immobilization. This year studies on crystal phase behavior have concentrated on glasses proposed for immobilization of defense wastes. Investigations of liquid-liquid phase separation have involved a broad range of nuclear waste glasses.

\section{EFFECTS OF ALUMINUM AND IRON ON SPINEL FORMATION IN WASTE GLASSES}

As a class defense wastes contain more aluminum, iron, nickel, chromium, and manganese than the wastes expected from the reprocessing of commercial power reactor fuels; and some TRU wastes contain more aluminum, nickel, and chromium than commercial wastes. As a result, borosilicate glasses formulated to contain defense or TRU wastes often have crystals with spinel structure of the general composition $(\mathrm{Ni}, \mathrm{Mn})(\mathrm{Fe}, \mathrm{Cr})_{2} \mathrm{O}_{4}$. The spinels have rather high liquidus temperatures (as high as $1400^{\circ} \mathrm{C}$ ) and, as a result, are often present in the melt at processing temperatures. With specific gravities of about 6 , the spinel crystals tend to settle to the bottom of glass melts, which usually have overall specific gravities of 2.5 to 3 . This settling is a concern in engineering-scale continuous melting of waste glasses because the settled spinels may form a highly viscous mass on the melter floor and subsequently block the drain.

The HLWIP has conducted previous studies of spinel formation and settling (Mendel et al. 1975) and of the effect of glass formulation on spinel yield (Ross 1978). A study completed this year as part of the TRUWIP investigated the interaction of aluminum and iron in the formation of spinel. The study revealed that increasing the concentration of either aluminum or iron in a glass causes increased spinel formation even though aluminum is not contained in these crystals. The aluminum atoms apparently preferentially occupy the sites in the glass structure where iron, nickel, or manganese are normally located, which results in exclusion of the transition metals from the glassy network and forces spinel formation. 
A series of melts were made in which $\mathrm{Fe}_{2} \mathrm{O}_{3}$ and $\mathrm{Al}_{2} \mathrm{O}_{3}$ concentrations were varied in a base glass typical of those known to produce spinel crystals. The base glass composition is shown in Table 11 .

Batches were melted in platinum crucibles for 2 hours at $1100^{\circ} \mathrm{C}$. The melts were then crushed and remelted in alumina crucibles at $1100^{\circ} \mathrm{C}$, cooled and held at $1000^{\circ} \mathrm{C}$ for 2 hours to promote crystal formation, and finally cooled at $\sim 100^{\circ} \mathrm{C} /$ hour to room temperature. The resulting material was broken out of the crucible and examined by $x$-ray diffraction for crystalline type and content.

Figure 25 plots the results from these melts in the form of isocrystallinity curves plotted as a function of $\mathrm{Al}_{2} \mathrm{O}_{3}$ and $\mathrm{Fe}_{2} \mathrm{O}_{3}$ content. As can be seen, above certain $\mathrm{Al}_{2} \mathrm{O}_{3}$ and $\mathrm{Fe}_{2} \mathrm{O}_{3}$ concentrations increases in either oxide cause enhanced spinel formation. At low spinel levels there is a stronger sensitivity to iron than to aluminum. (The 0 wt $\%$ spinel isocrystallinity curve goes through 5 mole\% $\mathrm{Fe}_{2} \mathrm{O}_{3}$ plus 2 mole\% $\mathrm{Al}_{2} \mathrm{O}_{3}$ on the iron-rich end whereas it goes through 10 mole $\% \mathrm{Al}_{2} \mathrm{O}_{3}$ plus 2 mole\% $\mathrm{Fe}_{2} \mathrm{O}_{3}$ on the aluminum-rich end.) At higher spinel levels, however, the sensitivity to alumina increases and the isocrystallinity curves approach a slope closer to $1: 1 \quad \mathrm{Fe}_{2} \mathrm{O}_{3}: \mathrm{Al}_{2} \mathrm{O}_{3}$.

These results imply that in order to avoid spinel formation it would be best not to blend wastes rich in iron with wastes rich in aluminum. Separate immobilization of such wastes will allow higher net waste loadings without higher spinel yields. However, since spinel may not be detrimental to glass properties such as chemical durability, the only incentive to avoid spinel formation may be the possibility of plugging continuous ceramic melter drains.

TABLE 11. Composition of Base Glass Used in Spinel Formation Study

\begin{tabular}{lr} 
COMPONENT & wt\% \\
\cline { 1 - 2 } $\mathrm{SiO}_{2}$ & 44.6 \\
$\mathrm{~B}^{2} \mathrm{O}_{3}$ & 13.0 \\
$\mathrm{Na}_{2} \mathrm{O}$ & 14.1 \\
$\mathrm{Li}_{2} \mathrm{O}$ & 3.0 \\
$\mathrm{CaO}$ & 14.0 \\
$\mathrm{MgO}$ & 2.1 \\
$\mathrm{~K}_{2} \mathrm{O}$ & 0.7 \\
$\mathrm{MnO}_{2}$ & 3.0 \\
$\mathrm{NiO}_{\mathrm{TiO}}$ & 3.2 \\
$\mathrm{ZnO}$ & 2.1 \\
& 0.4
\end{tabular}




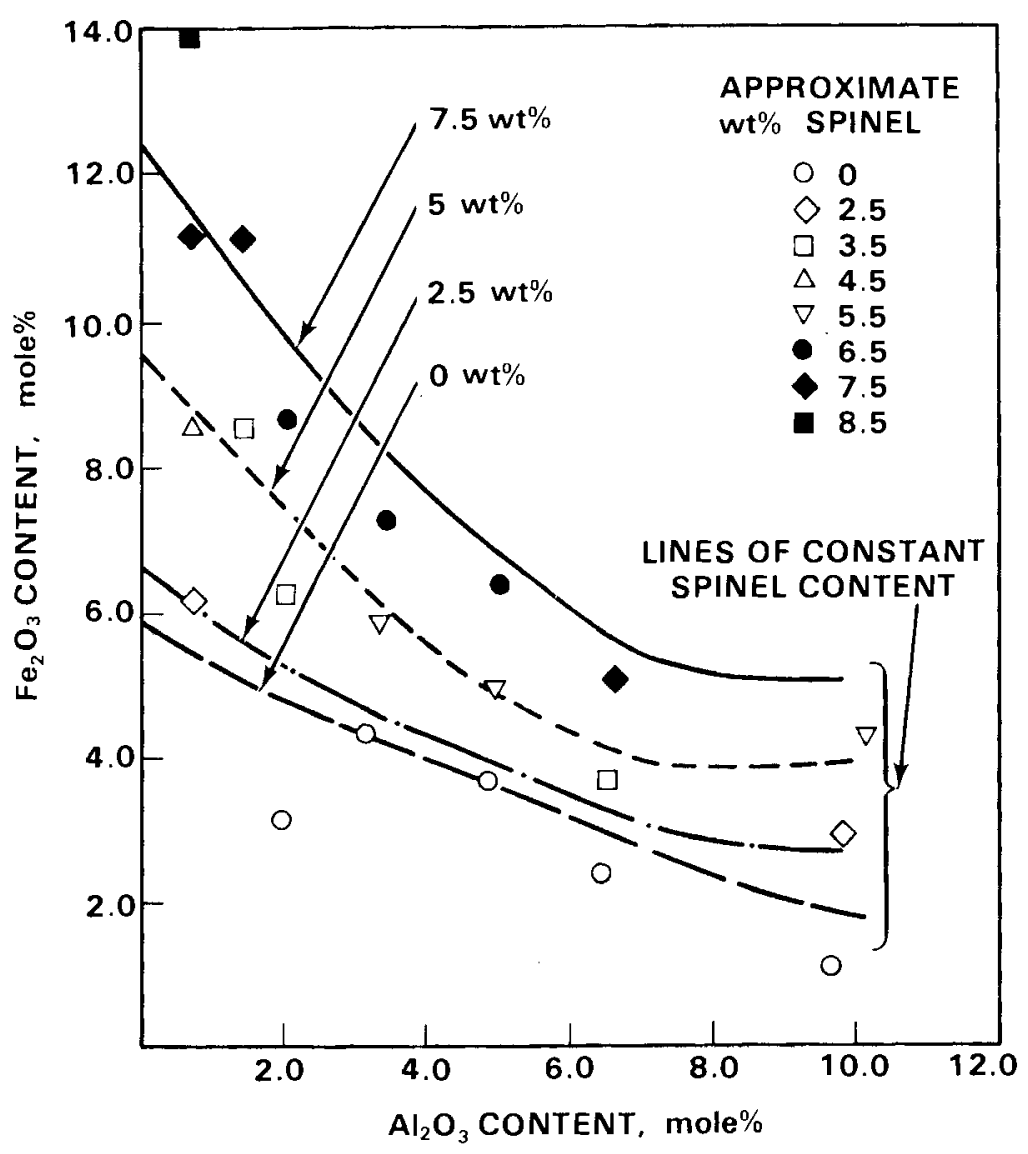

FIGURE 25. Effect of Iron and Aluminum on Formation of Spinel Crystals in a Glass

Addition of both iron oxide and aluminum oxide results in spinel precipitation from nuclear waste glasses, and increases in either oxide will increase the amount of spinel formed in a meit. This is an interesting phenomenon since aluminum is not found in the spinel crystal, which is composed of iron, nickel, and manganese oxides. Aluminum may be preferentially occupying sites in the glass structure that are otherwise occupied by iron, nickel, and manganese, causing their precipitation as spinel crystals.

\section{DEVITRIFICATION BEHAVIOR OF THREE DEFENSE WASTE GLASSES}

Although spinel is the principal crystalline phase formed at high temperatures in defense waste glass melts, additional phases form when these glasses are heat treated at lower temperatures $\left(500-850^{\circ} \mathrm{C}\right)$. Work funded by the Savannah River Defense Waste Processing Facility Support program this year studied the devitrification behavior of three Savannah River Laboratory (SRL) defense waste glasses in detail.

The study was aimed at evaluating crystallization behavior under conditions related to expected melter operating temperatures and cooling rates of large canisters. Crystal growth was examined by $x-$ ray diffraction, SEM, and optical metallography. Both constant temperature annealing and constant cooling rate experiments were used to determine the effects of 
viscosity, composition, and heat treatment on phase formation and microstructure. The three glass compositions studied are shown in Table 12 along with glass viscosities at $850^{\circ} \mathrm{C}$. Differences in glass composition represent a change in both waste and alkali composition. Glasses $\mathrm{C}-411$ and $\mathrm{T}-411$ are similar in composition except that $\mathrm{C}-411$ contains more $\mathrm{Al}_{2} \mathrm{O}_{3}$ while T-411 contains more $\mathrm{MnO}_{2}, \mathrm{NiO}$, and $\mathrm{Fe}_{2} \mathrm{O}_{3}$. In turn, glasses T-411 and T-211 are similar except that $T-411$ contains more $L_{2}{ }_{2} 0$ while $T-211$ contains more $\mathrm{Na}_{2} \mathrm{O}$.

Figures $26(\mathrm{a}-\mathrm{c})$ are micrographs of the three glasses after slow cooling at $7^{\circ} \mathrm{C} /$ hour from remelts at $1100^{\circ} \mathrm{C}$, and Figures $26\left(\mathrm{~d}-\mathrm{f}\right.$ ) show the glasses after annealing for 15 days at $750^{\circ} \mathrm{C}$. The variable composition spinel phase $(\mathrm{Ni}, \mathrm{Mn}) \mathrm{Fe}_{2} \mathrm{O}_{4}$ is found in all three glasses after both heat treatments. Three other phases are found: $\mathrm{NaAlSiO}_{4}$, $\mathrm{NaFeSi}_{2} \mathrm{O}_{6}$, and $\mathrm{Li}_{2} \mathrm{SiO}_{3}$. Multiphase devitrification regions (composed of a glassy phase, spinel, $\mathrm{NaAlSiO}_{4}$, and $\mathrm{Li}_{2} \mathrm{SiO}_{3}$ ) are present in the slow-cooled $\mathrm{C}-411$ sample, Figure 26(a).

Phase yield curves based on a series of 4-day anneals at temperatures ranging from 400 to $1100^{\circ} \mathrm{C}$ are shown in Figure $27(\mathrm{a}-\mathrm{C})$. The maxima of these yield curves indicate the annealing temperature most favorable to growth of the corresponding crystalline phase.

Comparison of $\mathrm{C}-411$ and $\mathrm{T}-411$ results reveals the effects of $\mathrm{Al}_{2} \mathrm{O}_{3}$ versus $\mathrm{Fe}_{2} \mathrm{O}_{3}, \mathrm{NiO}$, and $\mathrm{MnO}_{2}$. Even though the high level of $\mathrm{Al}_{2} \mathrm{O}_{3}$ causes $\mathrm{C}-411$ to have the highest viscosity of the three glasses, extensive devitrification occurred in C-411 during slow cooling, Figure 26(a). It is well known that nucleation and growth of crystals are controlled by ion diffusivities, which are in turn controlled by viscosity. However, the composition of C-411 promotes secondary nucleation and cooperative growth of spinel, $\mathrm{NaAlSiO}_{4}$, and $\mathrm{Li}_{2} \mathrm{SiO}_{3}$ in the

TABLE 12. Savannah River Laboratory Simulated Waste Glass Compositions

\begin{tabular}{lrrr}
\cline { 2 - 2 } & $\mathrm{C}-411$ & $\mathrm{~T}-411$ & $\mathrm{~T}-211$ \\
\cline { 2 - 2 } $\mathrm{SiO}_{2}$ & 43.8 & 42.2 & 43.7 \\
$\mathrm{~B}_{2} \mathrm{O}_{3}$ & 8.3 & 7.9 & 7.8 \\
$\mathrm{CaO}$ & 5.0 & 5.1 & 5.2 \\
$\mathrm{MnO}_{2}$ & 2.6 & 4.0 & 4.0 \\
$\mathrm{NiO}$ & 0.6 & 1.9 & 1.9 \\
$\mathrm{Fe}_{2} \mathrm{O}_{3}$ & 8.0 & 15.1 & 15.2 \\
$\mathrm{Al}_{2} \mathrm{O}_{3}$ & 11.7 & 3.1 & 3.6 \\
$\mathrm{Na}_{2} \mathrm{O}$ & 9.4 & 9.0 & 15.1 \\
$\mathrm{Li}_{2} \mathrm{O}$ & 9.4 & 8.8 & 3.1 \\
$\mathrm{Na}_{2} \mathrm{SO}_{4}$ & - & 0.4 & 0.4 \\
$\mathrm{ZEOLITE}(\mathrm{a})$ & 1.2 & 2.5 & - \\
& 100.0 & 100.0 & 100.0 \\
VISCOSITY & & & \\
(POISE) & & & 190 \\
AT 850 & & &
\end{tabular}

(a) THE MATERIAL USED WAS A CALCIUMALUMINUM-SILICATE. 


\section{SLOW COOLED AT $7^{\circ} \mathrm{C} / \mathrm{HOUR}$ FROM REMELTS AT $1100^{\circ} \mathrm{C}$}

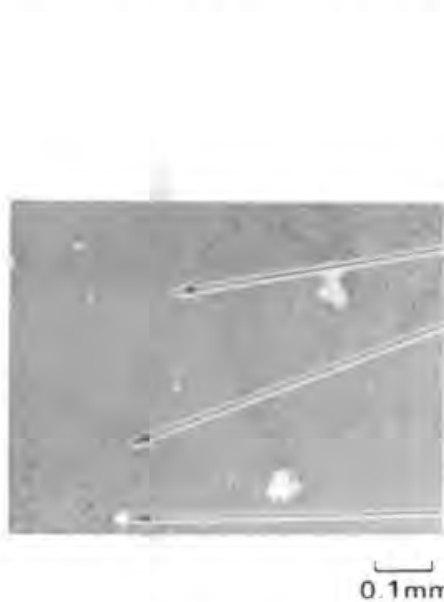

a) Glass SRL-C-411
GLASS

MATRIX

MULTIPHASE

DEVITRIFICATION

REGIONS

\section{CRUCIBLE WALL}

(Ni, $\mathrm{Mn}) \mathrm{Fe}_{2} \mathrm{O}$ SPINEL

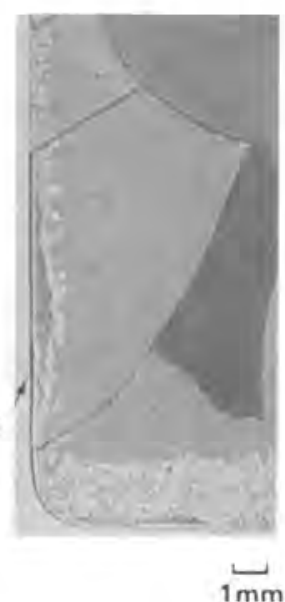

b) Glass SRL-T-411

\section{(Ni. $\mathrm{Mn}) \mathrm{Fe}_{2} \mathrm{O}_{6}$ SPINEL \\ $\mathrm{NaFeSi}_{2} \mathrm{O}_{6}$ \\ SETTLED \\ SPINEL \\ CRYSTALS}

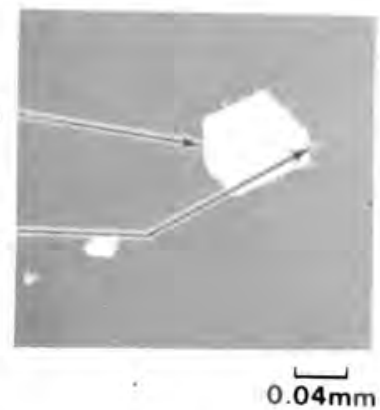

c) Glass SRL-T-211

\section{ANNEALED FOR 15 DAYS AT $750^{\circ} \mathrm{C}$}

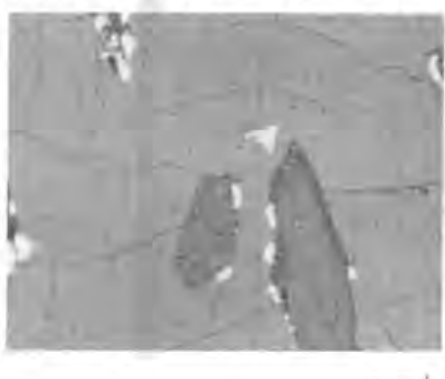

$0.1 \mathrm{~mm}$

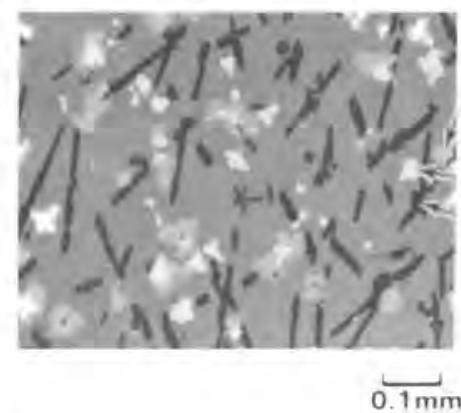

e) Glass SRL-T-411
$\mathrm{NaFeSi}_{2} \mathrm{O}_{6}$

( $\mathrm{Ni}, \mathrm{Mn}) \mathrm{Fe}_{2} \mathrm{O}_{4}$

SPINEL

$\mathrm{Li}_{2} \mathrm{SiO}_{3}$

$\mathrm{NaFeSi}_{2} \mathrm{O}_{6}$

( $\mathrm{Ni}, \mathrm{Mn}) \mathrm{Fe}_{2} \mathrm{O}_{4}$ SPINEL

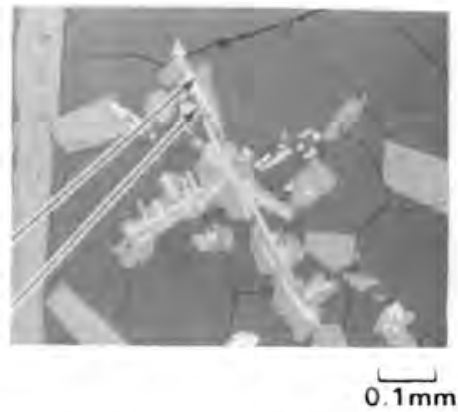

f) Glass SRL-T-211

d) Glass SRL-C-411

FIGURE 26. Crystal Phases Formed in Three Defense Waste Glasses During Two Heat Treatments

Optical micrographs of three Savannah River Laboratory (SRL) defense waste glasses were investigated. Samples (a), (b), and (c) were cooled at $7^{\circ} \mathrm{C} /$ hour from $1100^{\circ} \mathrm{C}$ melts; the other samples were annealed for 15 days at $750^{\circ} \mathrm{C}$. During both heat treatments, crystals with a spinel structure and a composition of $(\mathrm{Ni}, \mathrm{Mn}) \mathrm{Fe}_{2} \mathrm{O}_{4}$ formed in all three glasses. During slow cooling, glasses T-411 and T-211 formed high crystal yields that are principally spinel. In both glasses, the crystals settled to the bottom of the crucible. Glass C-411 formed multiphase devitrification regions as well as spinel during slow cooling.

In glass $\mathrm{T}-211$ spinel serves as nucleation sites for $\mathrm{NaFeSi}_{2} \mathrm{O}_{6}$ during both heat treatments; while in glass $\mathrm{C}-411$, spinel was nucleated by $\mathrm{Li}_{2} \mathrm{SiO}_{3}$ during annealing. The large multiphase devitrification regions shown in micrographs (d) and ( $f$ ) caused extensive microcracking in glasses $\mathrm{C}-411$ and $\mathrm{T}-211$. During the same annealing treatment, glass T-411 produced a better dispersion of microcrystallites, and no cracking resulted. Glass T-411 contains more spinel-forming elements and less aluminum than glass C-411 and more lithium and less sodium than glass T-211. These compositional differences may account for the better dispersion of small crystallites in glass T-411. 


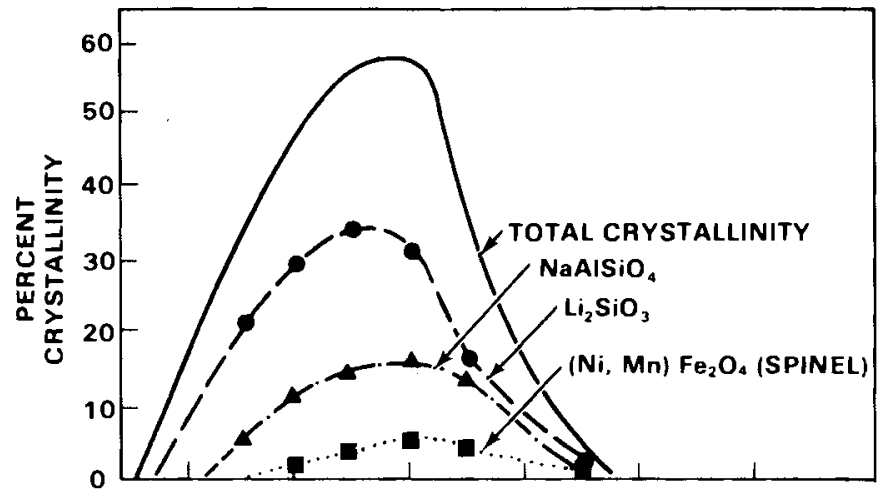

(a) Glass SRL-C-411

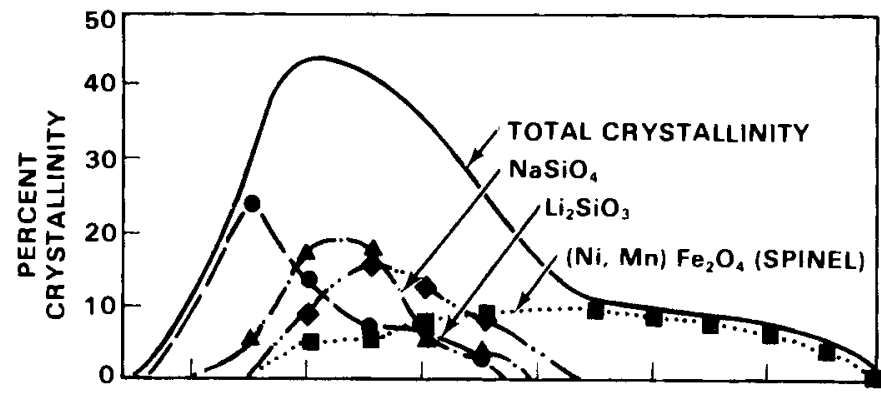

(b) Glass SRL-T-411

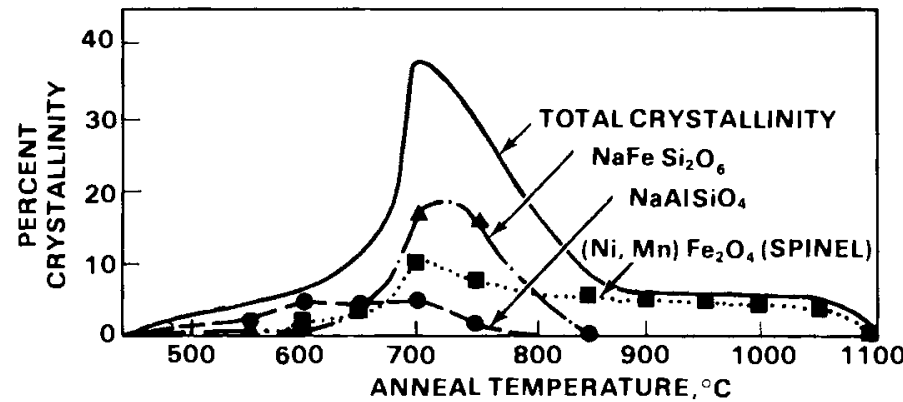

(c) Glass SRL-T-211

FIGURE 27. Phase Yield Curves for 4-Day Anneals of Three Defense Waste Glasses

Three Savannah River Laboratory (SRL) defense waste glasses were annealed for 4 days at temperatures ranging from 450 to $1100^{\circ} \mathrm{C}$. Phase yield curves reflect composition differences among the three glasses; total crystallinity curves are also indicated.

Glasses C-411 and T-411 are similar in composition except that $C-411$ contains more aluminum and less iron, manganese, and nickel than T-411. This composition difference is evidenced by the depressed and retarded yield of ( $\mathrm{Ni}, \mathrm{Mn}$ ) Fe $\mathrm{O}_{4}$ spinel in $\mathrm{C}-411$ as compared to T-411. Comparison of the same figures shows an increased yield of $\mathrm{NaAlSiO}_{4}$ in glass $\mathrm{C}-411$.

Glasses T-411 and T-211 are similar in composition except that T-211 has more sodium and less lithium than T-411. This alkali substitution is manifested by the absence of $\mathrm{Li}_{2} \mathrm{SiO}_{3}$ yield and by much less devitrification at $650^{\circ} \mathrm{C}$ for glass T-211 as compared to glass T-411. 
form of an advancing devitrification interface. This is a short-range diffusion phenomenon that overcomes the barrier posed by the high viscosity. This cooperative growth mechanism is reflected by the concentricity of the phase yield curve maxima for C-411, Figure $27(a)$. Cooperative growth involves short-range rather than the long-range diffusion required for the growth of large, separated crystals.

The fact that T-411 has the lowest viscosity of the three glasses is evident in Figure 26(b), which shows settling of large spinel crystals. T-411 forms more spinel and forms it at higher temperatures than does $C-411$, Figure $27(a, b)$, due to a higher concentration of iron, nickel, and manganese. The dispersion of phase yield maxima for T-411, Figure 27(b), precludes the occurrence of cooperative growth. Thus, phase growth during slow cooling would have to rely on long-range diffusion rather than short-range rearrangement. Since the phase yield maxima occur at 550 to $650^{\circ} \mathrm{C}$, the viscosity is high enough to prevent long-range diffusion; therefore, spinel is the only phase that forms in T-411 during slow cooling.

Fifteen-day annealing at $750^{\circ} \mathrm{C}$ produced large crystals and microcracking in glass $\mathrm{C}-411$ but smaller, better distributed crystals and no cracking in T-411. In C-411 the spinel is nucleated and grows on the lithium silicate phase; however, both of the phases in T-411 grow independently of one another and thus are better dispersed.

Comparison of results for $\mathrm{T}-411$ and $\mathrm{T}-211$ reveals the effects of trading $\mathrm{Li}_{2} \mathrm{O}$ for $\mathrm{Na}_{2} \mathrm{O}$. During slow cooling, some spinel forms in T-211 but not as much as in T-411. The fact that substitution of $\mathrm{Li}_{2} \mathrm{O}$ for $\mathrm{Na}_{2} \mathrm{O}$ causes higher spinel yields was reported in the annual report for 1979. T-211 has a moderately higher viscosity than T-411; thus, the spinel did not settle as extensively. In addition, higher sodium content in T-211 enabled a small amount of $\mathrm{NaFeSi}_{2} \mathrm{O}_{6}$ to nucleate and grow on the spinel during slow cooling.

Fifteen-day annealing of T-211 also produced large crystals and microcracking, Figure 26(f). The spinel acts as nucleation sites for $\mathrm{NaFeSi}_{2} \mathrm{O}_{6}$, which then grows at the expense of the spinel; this was demonstrated in an isothermal experiment (May 1979).

Of the three glasses, T-411 had the most favorable microstructure after the 15-day anneal. It produced small, well-dispersed crystallites that caused no microcracking. However, the most favorable microstructure after slow cooling was observed in glass $C-411$, which produced no spinel settling and had large crystals. Slow cooling may more closely approximate the actual thermal cycle during large-scale melting and casting in large canisters; however, depending upon the self-heating in actual practice, a combination of slow cooling followed by annealing may be more representative.

It can be concluded that composition variation and different heat treatments resulted in greater changes in microstructure than did the changes in viscosity.

\section{LIQUIO-LIQUID PHASE SEPARATION}

While crystalline phase behavior in nuclear waste glasses has received much attention in the past several years, the study of liquid-liquid or glass-in-glass phase separation in these materials has received less consideration. The subject is under study by Professor Minoru Tomozawa at Rensselaer Polytechnic Institute under contract to the HLWIP. 
Phase separation occurs in a glass melt when the total Gibbs free energy of the system can be reduced by separation into two immiscible liquids of differing composition. Depending upon factors such as the relative density of the liquids, their viscosities, the interphase surface energy, and melt conditions, the two liquids may separate on a gross macroscopic level resulting in two separate liquid layers; or they may remain separated only on a microscopic scale. Total separation into two layers has been observed and studied (Mendel et al. 1975; Ross 1978) in a nuclear waste glass when alkali molybdate was found to float to the top of 76-68 glass melts. Perhaps the occurrence of microscale phase separation was not recognized until recently because nuclear waste glasses are generally opaque due to high transition metal content.

Because of this opacity, microscale phase separation in nuclear waste glasses must be studied by transmission electron microscopy on carbon-film replicates of fractured, acidetched surfaces. Figures $28(a)$ and $28(b)$ show photographs of two reference nuclear waste glasses obtained by such techniques. Since beginning this work, all borosilicate nuclear waste glasses observed in this manner by Tomozawa have shown microscale liquid-liquid phase separation. In all cases, the dispersed droplet phase protrudes from the acid-etched surface, which indicates that the dispersed phase is more chemically durable than the matrix phase. Although no quantitative measurements of phase compositions have been performed, it is presumed that the dispersed phase is enriched in silica while the matrix phase is enriched in alkali metals and boron. Since the matrix phase controls the chemical durability (Takamori and Tomozawa 1978), it is expected that phase separation acts to reduce the chemical durability of borosilicate nuclear waste glasses. Reduction or elimination of the phase separation should therefore improve nuclear waste glass durability by distributing the silica throughout the glass matrix more homogeneously.

Tests where samples were water-quenched from the melt showed that this rapid cooling does not significantly reduce phase separation. This indicates that the immiscibility temperature is high (probably well above $1000^{\circ} \mathrm{C}$ ) and the kinetics of separation are fast. Thus, it does not appear that heat treatment would provide a practical method of controlling phase separation.

Adding reducing agents to the melt appears to be the most promising method of controlling phase separation. The gross separation of alkali molybdate phase from glass 72-68 was controlled in this manner by adding silicon metal to the melt (Ross et al. 1978; Takamori and Tomozawa 1978; Ross 1978). Microscale phase separation can also be controlled in this manner (Tomozawa et al. 1979). Figures 29(a, b) illustrate an example of reducing microscale phase separation by adding carbon to the melt.

Current work includes quantification of the gain in chemical durability achieved by elimination of phase separation, characterization of phase compositions by scanning transmission electron microscopy, and development of the ability to predict immiscibility composition regions in complex glass systems. 


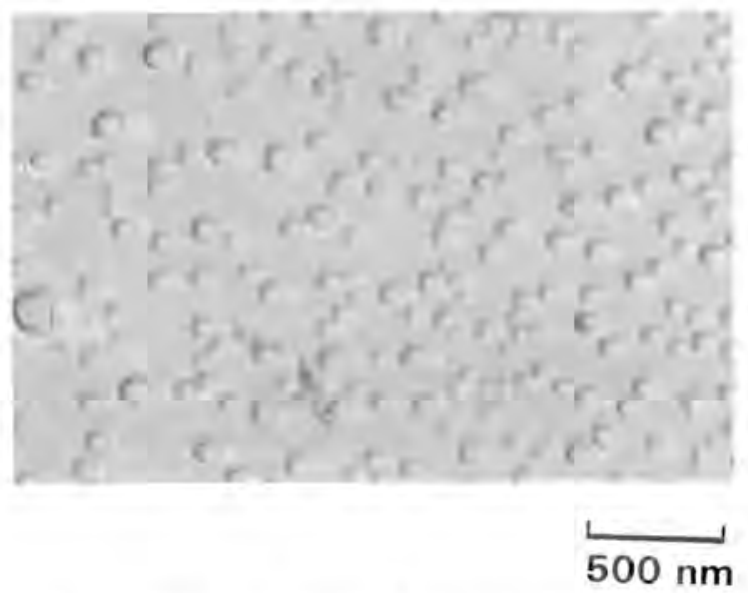

(a) Glass $76-68,1050^{\circ} \mathrm{C}, 3$ Hours

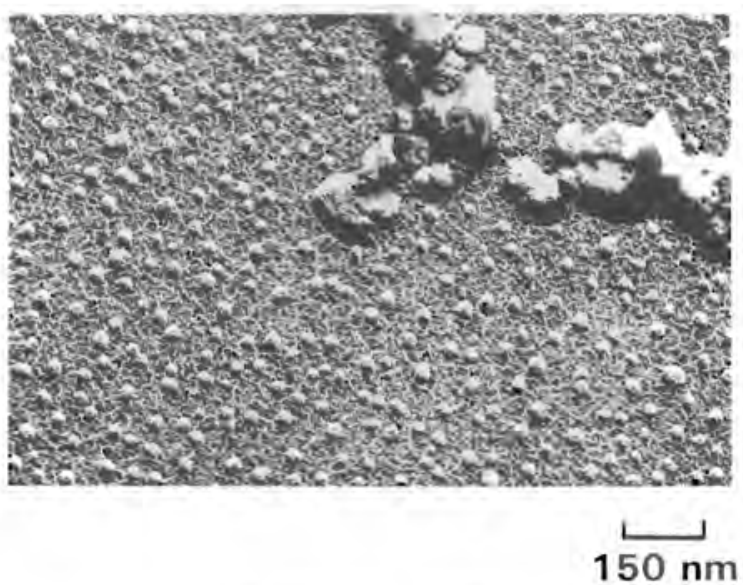

(b) Glass TDS $/ 211,1150^{\circ} \mathrm{C}, 1$ Hour

FIGURE 28. Liquid-Liquid Phase Separation in Reference Nuclear Waste Glasses

Liquid-1iquid phase separation, which is similar to dispersion of oil droplets in water, occurs in all of the borosilicate nuclear waste glasses studied so far. The micrographs of two reference glasses (76-68 and TDS/211) are transmission electron microscope replicates of fractured surfaces etched in acid. The dispersed droplet phase etches more slowly than the matrix, indicating that the droplets are enriched in silica and the matrix is enriched in alkali and boron. Thus, elimination of the phase separation would increase the chemical durability of these glasses. Rapid quenching from the melt does not reduce the phase separation significantly, which indicates that the immiscibility temperature is high. 


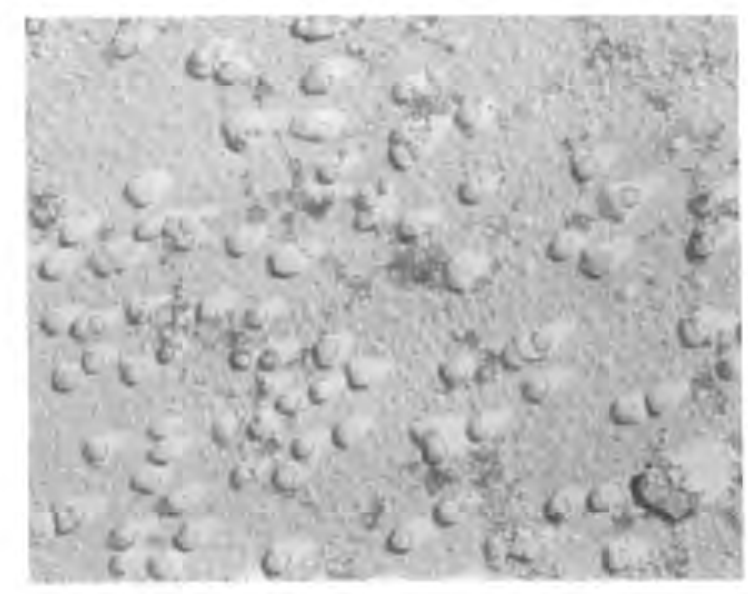

\section{$500 \mathrm{~nm}$}

(a) Glass $77-107,1150^{\circ} \mathrm{C}, 3$ Hours

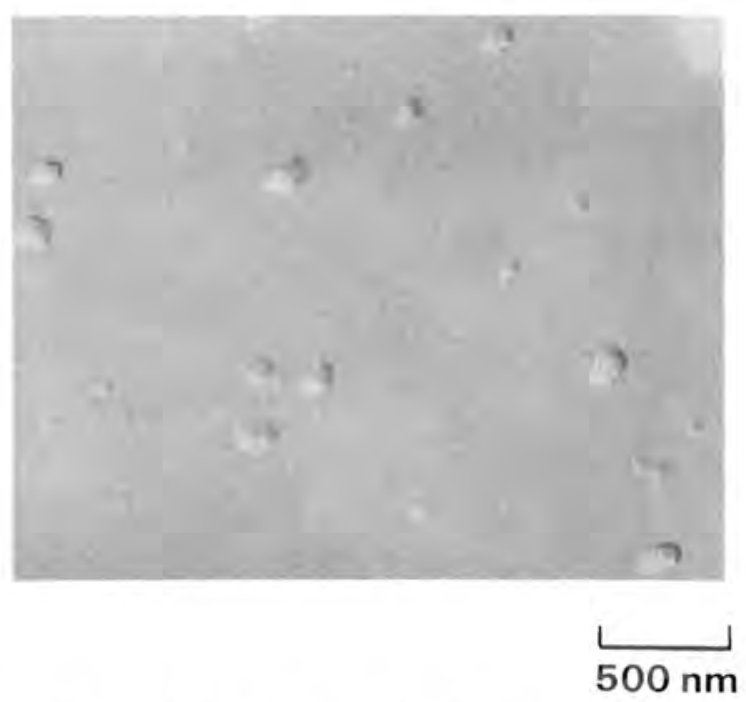

(b) Glass $77-107$ with $0.5 \mathrm{wt} \%$ Carbon, $1150^{\circ} \mathrm{C}, 3$ Hours

FIGURE 29. Reduction of Dispersed Phase Volume Fraction by Adding Carbon

Adding a small amount of carbon to powdered glass before remelting greatly reduces the volume fraction of the dispersed phase. It is believed that this effect is caused by reduction of multivalent cations by the carbon. Studies have shown that decreasing the cationic field strength of a glass decreases its tendency to phase separate. Although leaching tests are not yet completed, it is expected that glass (b) will be more chemically durable than glass (a). 


\section{RADIATION EFFECTS}

Radiation damage effects in a number of nuclear waste forms and specific crystalline materials relevant to waste form development and characterization have been or are being investigated as part of the HLWIP, the AWFP, and the BES program. The results of studies on borosilicate waste glasses have been discussed in previous annual reports.

Current and planned work focuses on investigations of alpha-recoil and alpha particle induced damage in crystalline waste forms and on the effects of transmutation in glasses and crystalline forms. Table 13 presents a list of materials that have been or are now being tested. In addition, an investigation of the annealing of radiation damage by heating of borosilicate glass has been completed.

\section{RADIATION DAMAGE IN CRYSTALLINE CERAMICS}

The primary source of displacement damage in nuclear waste solids results from alpha decay of the long-lived actinide isotopes. In alpha decay, a high-energy alpha particle $(\sim 5.5 \mathrm{MeV})$ and a recoil nucleus $(\sim 0.1 \mathrm{MeV})$ are produced. Since the crystals are generally small in crystalline waste forms $(\sim 0.1-10 \mu \mathrm{m})$, the alpha particle (with a range of $\sim 20 \mu \mathrm{m}$ ) effectively bombards the entire solid, including the nonactinide-containing phases. The recoil nucleus, however, is confined to the phase in which it is chemically incorporated because of its short range $(\sim 0.01 \mu \mathrm{m})$. Most radiation damage studies have been concerned with alpha-recoil damage (i.e., damage due to both alpha particle and recoil nucleus) in the host phase; until now little attention has been given to alpha damage from external bombardment of the nonactinide-containing phases.

As part of the Radiation Damage in Ceramics Program (sponsored by BES-DOE), both internal alpha-recoil and external alpha bombardment damage in several crystal structures are being studied. The work includes studies of damage ingrowth and recovery in several alphairradiated crystalline materials (summarized here). Two papers on these studies have been reported (Turcotte, Weber, and Roberts 1980 and an unpublished work by $W$. J. Weber that has been accepted for publication in the Journal of Nuclear Materials, PNL-SA-8574). Other ongoing studies include the investigation of amorphization in actinide-doped and alphairradiated apatite and the investigation of damage ingrowth in alpha-irradiated pyrochlore, zirconolite, hollandite, and pollucite.

The change in lattice parameter with alpha dose is shown in Figure 30 for several single crystal and polycrystalline materials irradiated with alpha particles emitted isotropically from an effectively semi-infinite ${ }^{238} \mathrm{PuO}_{2}$ source; the experimental techniques are described in the paper by weber. With the exception of $\mathrm{CaF}_{2}$, which exhibits no measurable change, the damage ingrowth follows exponential behavior predicted by a model and described by the relation

$$
\Delta a / a_{0}=A\left[1-\exp \left(-B D_{a}\right)\right]
$$


TABLE 13. Tests Completed or Under Way in Radiation Damage

\begin{tabular}{|c|c|}
\hline ACTINIDE DOPING & $\begin{array}{l}\text { ALPHA PARTICLE } \\
\text { BOMBARDMENT(a) }\end{array}$ \\
\hline \multicolumn{2}{|l|}{ CRYSTALLINE MATERIALS } \\
\hline $\begin{array}{l}\mathrm{PuO}_{2}(\mathrm{a}) \\
\mathrm{CmO}_{2}(\mathrm{a}) \\
\mathrm{Ca}^{2} \mathrm{Nd}_{8}\left(\mathrm{SiO}_{4}\right) \mathrm{O}_{2}(\mathrm{a}) \\
\mathrm{ZrSiO}_{4}(\mathrm{a}) \\
\mathrm{CaZrTi}_{2} \mathrm{O}_{7}(\mathrm{c}) \\
\mathrm{Gd}_{2} \mathrm{Ti}_{2} \mathrm{O}_{7}(\mathrm{c}) \\
\mathrm{ThSiO}_{4}(\mathrm{c}) \\
\text { SUPERCALCINE-SPC-4(b) } \\
\text { SUPERCALCINE SPC-2(c) } \\
\text { CEMENT + } 10 \% \text { PW-9(c) } \\
\text { CELSIAN GLASS CERAMIC (b) } \\
\text { CELSIAN GLASS CERAMIC (c) }\end{array}$ & $\begin{array}{l}\mathrm{UO}_{2} \\
\mathrm{PuO}_{2} \\
\mathrm{BaF}_{2} \\
\mathrm{CaF}_{2} \\
\mathrm{Y}_{2} \mathrm{O}_{3} \\
\mathrm{CsAISi}{ }_{2} \mathrm{O}_{6} \\
\mathrm{CaZrTi}_{2} \mathrm{O}_{7} \\
\mathrm{CeO}_{2} \\
\mathrm{SrF}_{2} \\
\mathrm{NiFe}_{2} \mathrm{O}_{4} \\
\mathrm{Ca}_{2} \mathrm{Nd}_{\mathrm{B}}\left(\mathrm{SiO}_{4}\right)_{6} \mathrm{O}_{2} \\
\mathrm{BaAl}_{2} \mathrm{Ti}_{6} \mathrm{O}_{16} \\
\mathrm{Gd}_{2} \mathrm{Ti}_{2} \mathrm{O}_{7}\end{array}$ \\
\hline \multicolumn{2}{|l|}{ BOROSILICATE GLASSES (b) } \\
\hline \multicolumn{2}{|l|}{$\begin{array}{l}72.68 \\
76-68 \\
77-260 \\
\text { EUROPEAN GLASS } \\
\text { LEAD GLASS }\end{array}$} \\
\hline \multicolumn{2}{|c|}{$\begin{array}{l}\text { (a) FUNDED BY BES } \\
\text { (b) HIGH-LEVEL WASTE IMMOBILIZATION PROGRAM } \\
\text { (c) ALTERNATIVE WASTE FORMS PROGRAM } \\
\text { (d) CONTAINS PW-9 WASTE } \\
\text { (e) CONTAINS PW-4 WASTE }\end{array}$} \\
\hline
\end{tabular}

where $A$ and $B$ are material- and structural-dependent constants and $D_{\alpha}$ is the alpha dose $\left(a / \mathrm{cm}^{2}\right)$. The values for $A$ and $B$ were determined by a least squares $f$ it of the data to the above expression and are given in Table 14 along with the change in unit cell volume $\left(\Delta V / V_{0}=3 \mathrm{a} / \mathrm{a}_{0}\right)$ predicted at saturation. These results illustrate that nonactinidecontaining phases can undergo significant lattice expansion as a result of alpha bombardment from adjacent actinide host phases.

Isochronal annealing studies of the alpha-irradiated single crystals have been carried out to understand the nature of the lattice defects responsible for lattice expansion. The fractional recovery of the lattice parameter for $\mathrm{UO}_{2}, \mathrm{BaF}_{2}$, and $\mathrm{SrF}_{2}$ is shown in $\mathrm{Figure} 31$. Three recovery stages are observed in $\mathrm{UO}_{2}$, suggesting at least three defect types; in $\mathrm{BaF}_{2}$ and $\mathrm{SrF}_{2}$ only a single recovery stage is observed. The nature of the defects responsible for these recovery steps has not been determined; but further studies, including correlation of the results with self-diffusivity data, are continuing. The results do indicate, by the presence of only a single recovery stage in the cases of $\mathrm{BaF}_{2}$ and $\mathrm{SrF}_{2}$, that one or more defect types, which are present in $\mathrm{UO}_{2}$, must be annealing during irradiation in these 


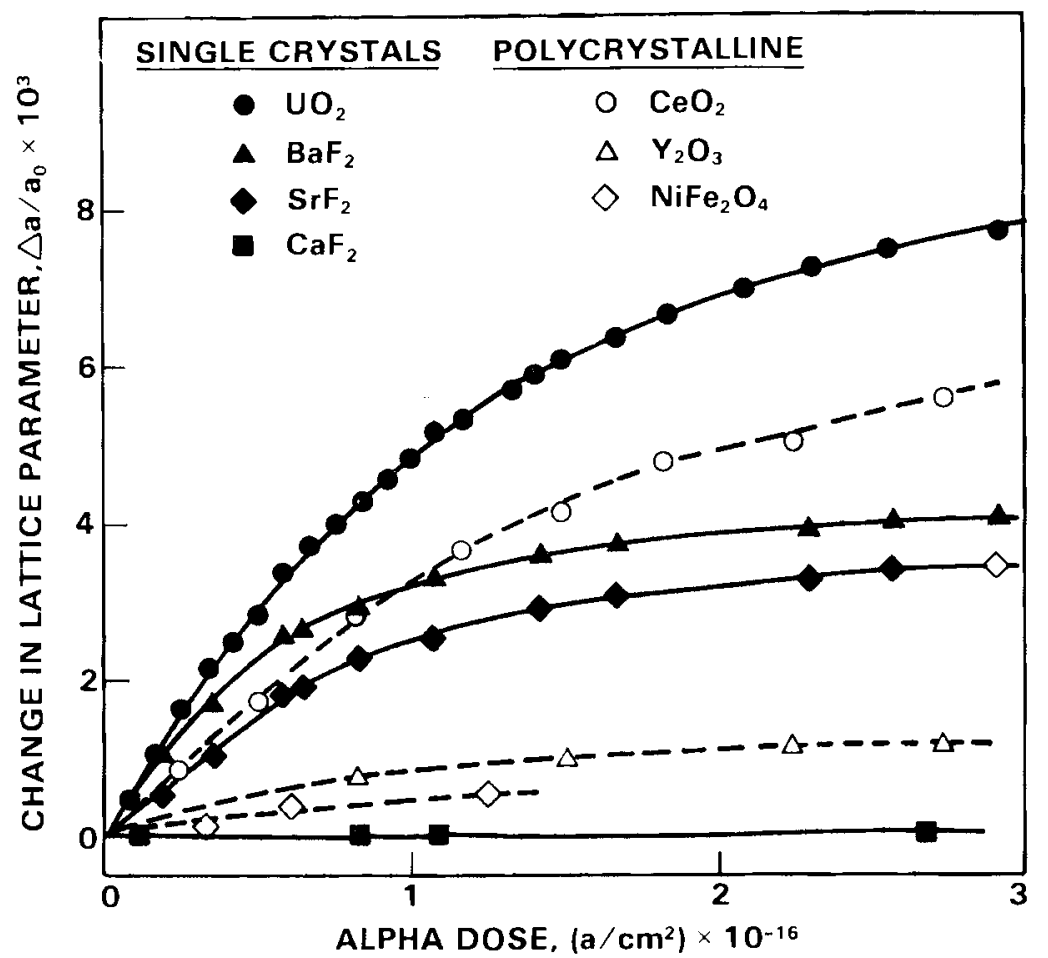

FIGURE 30. Radiation Damage in Crystalline Phases from Alpha Bombardment by an External Source

Changes in lattice parameter with alpha dose are shown for several single crystal and polycrystalline materials irradiated with alpha particles emitted from an external 238pu02 source. With the exception of $\mathrm{CaF}_{2}$, which exhibits no change, the damage ingrowth follows exponential behavior described by the relation: $\Delta a / a_{0}=A\left[1-\exp \left(-B D_{\alpha}\right)\right]$ where $A$ and $B$ are constants and $\mathrm{D}_{\alpha}$ is the alpha dose. These results illustrate that nonactinide-containing crystalline phases can undergo significant lattice expansion as a result of alpha bombardment from adjacent actinide-containing phases.

samples. This partly accounts for the lower lattice expansion observed in these crystals relative to $\mathrm{UO}_{2}$ and also suggests that at slightly elevated temperatures no lattice expansion may occur in $\mathrm{BaF}_{2}$ and $\mathrm{SrF}_{2}$.

The change in lattice parameter in $\mathrm{UO}_{2}$ as a function of displacements per atom (dpa) is shown in Figure 32 for three damage sources. The data clearly establish that alpha damage results in a larger lattice expansion and hence simple defect concentration than that observed under fission damage (wait 1967) or estimated for alpha-recoil damage from the selfdamage studies of other actinide dioxides (Turcotte 1976; Hurtgen and Fuger 1977; Noe and Fuger 1977; Mosley 1971). The extended defect clusters and thermal spikes produced by fission fragments (fission damage) and to a lesser extent by the recoil nuclei (alpha-recoil damage) have a significant effect on the simple defect concentration. The extended defects will act as defect sinks, while the thermal spikes will enhance recombination and defect mobility. These results suggest that the lattice expansion from alpha bombardment in 
TABLE 14. Experimentally Determined Constants for Damage Ingrowth Expression and the Predicted Change in Unit Cell Volume at Saturation

\begin{tabular}{|c|c|c|c|}
\hline SAMPLE & A & B. $\left(\mathrm{cm}^{2}\right)$ & $\mathrm{V} / \mathrm{v}_{0}, \%$ \\
\hline $\mathrm{UO}_{2}$ & $8.4 \times 10^{-3}$ & $0.85 \times 10^{-16}$ & 2.5 \\
\hline $\mathrm{CeO}_{2}$ & $7.3 \times 10^{-3}$ & $0.57 \times 10^{-16}$ & 2.2 \\
\hline $\mathbf{Y}_{2} \mathbf{O}_{3}$ & $1.2 \times 10^{-3}$ & $1.19 \times 10^{-16}$ & 0.4 \\
\hline $\mathrm{BaF}_{2}$ & $4.1 \times 10^{-3}$ & $1.47 \times 10^{-16}$ & 1.2 \\
\hline $\mathrm{SrF}_{2}$ & $3.6 \times 10^{-3}$ & $1.13 \times 10^{-16}$ & 1.1 \\
\hline $\mathrm{CaF}_{2}$ & $0.2 \times 10^{-3}$ & - & 0 \\
\hline $\mathrm{NiFe}_{2} \mathrm{O}_{4}$ & $1 \times 10^{-3}$ & - & 0.3 \\
\hline
\end{tabular}

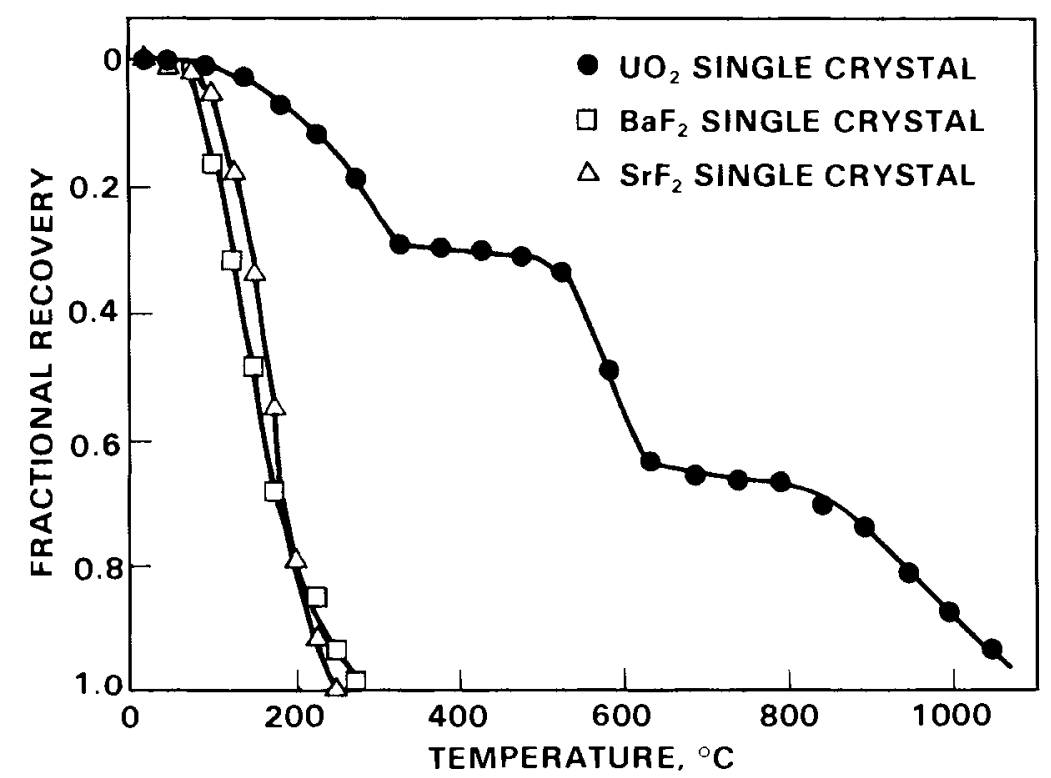

FIGURE 31. Recovery of Radiation Damage in Crystalline Phases by Thermal Annealing

Radiation damage as manifested by changes in the lattice parameter of irradiated crystals can be thermally annealed. The fractional recovery of the lattice parameter in alphairradiated single crystals of $\mathrm{UO}_{2}, \mathrm{BaF}_{2}$, and $\mathrm{SrF}_{2}$ is plotted as a function of annealing temperature. Three distinct recovery stages are observed for $\mathrm{UO}_{2}$, while only a single recovery stage is observed for $\mathrm{BaF}_{2}$ and $\mathrm{SrF}_{2}$. The results indicate that only one defect type may be present in $\mathrm{BaF}_{2}$ and $\mathrm{SrF}_{2}$. This accounts in part for the lower lattice expansion observed in $\mathrm{BaF}_{2}$ and $\mathrm{SrF}_{2}$ relative to $\mathrm{UO}_{2}$ and also suggests that at slightly elevated temperatures no lattice expansion may occur in $\mathrm{BaF}_{2}$ and $\mathrm{SrF}_{2}$.

nonactinide-containing waste phases can be greater than that occurring in actinide-containing phases. In addition, the results clearly establish that alpha and alpha-recoil damage in high-level nuclear waste solids cannot be accurately simulated by fission damage studies. 


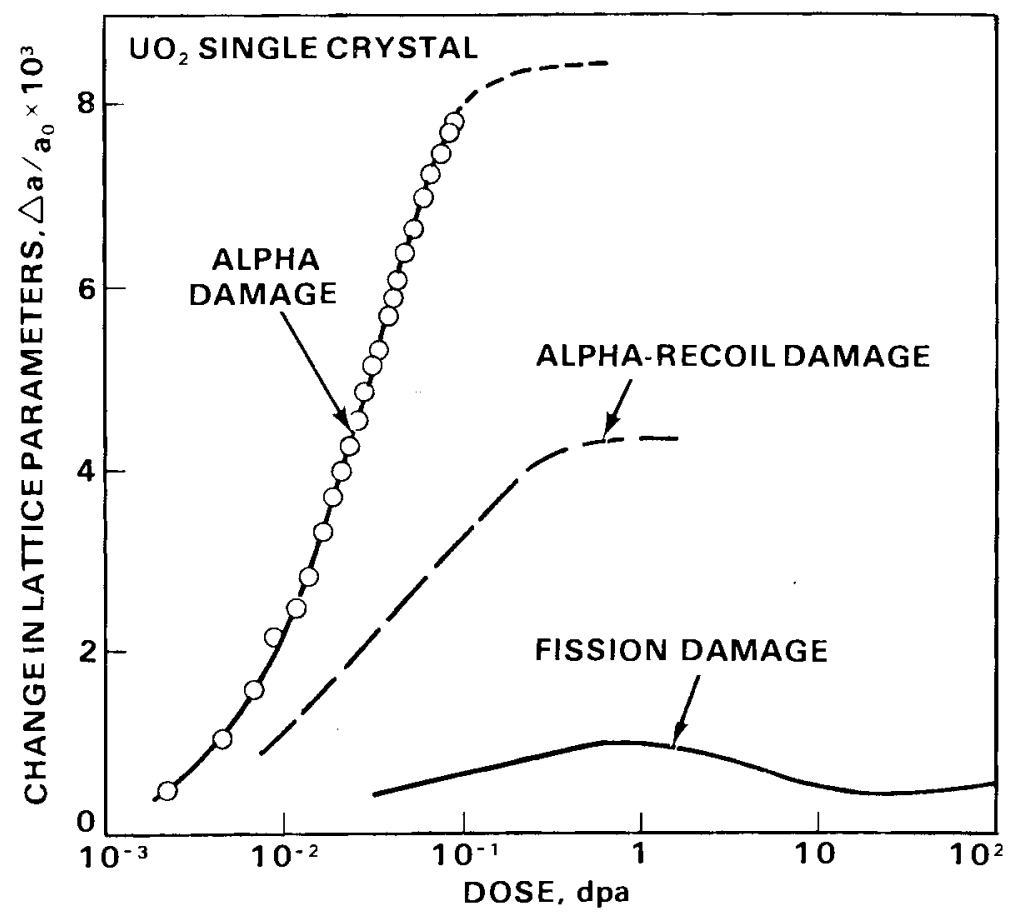

FIGURE 32. Comparison of Lattice Parameter Change Produced by Three Irradiation Sources in Single-Crystal $\mathrm{UO}_{2}$

The change in lattice parameter as a function of displacements per atom (dpa) in single crystals of $\mathrm{UO}_{2}$ is shown for three radiation sources. The data clearly establish that external alpha irradiation results in a greater change in lattice parameter and hence larger simple defect concentration than that observed for fission damage or estimated for alpharecoil damage. The effect of both fission fragments and recoil nuclei is to reduce the net concentration of simple defects by producing defect sinks and localized heating, which enhance the annealing of simple defects.

The results suggest that lattice expansion from alpha bombardment in nonactinidecontaining phases can be greater than that occurring in actinide-containing phases and that fission damage studies may not simulate alpha and alpha-recoil damage in high-level nuclear waste solids.

\section{RADIATION DAMAGE IN GLASS}

Radiation damage in glass is under study in the HLWIP. Previous studies have shown that irradiation-induced changes in borosilicate waste glasses tend to saturate at doses <6 $\times 10^{18}$ alpha decays $/ \mathrm{cm}^{3}$. The ingrowth of damage as measured by density change follows an exponential function similar to that observed for ceramics (see previous section). The fractional density change $\Delta \rho / \rho$ follows the expression

$$
\frac{\Delta \rho}{\rho}=A[1-\exp (-B n)]
$$

where $A$ and $B$ are constants and $n$ is the dose in alpha decays/g. 
The values for $A$ and $B$, obtained by computer-assisted curve fitting, and the saturation density change for the borosilicate glasses under study are presented in Table 15 . The usefulness of the equation for predicting glass behavior is quite limited because of the large variations in the constants for different glasses.

Recovery from radiation damage in the borosilicate glasses was investigated by an isochronal annealing experiment. Samples of five curium-doped glasses were held at temperatures of $100,200,300$, and $400^{\circ} \mathrm{C}$ for 7 days; and the stored energy was determined at each annealing temperature. (Density was also measured; however, the thermal effect on density was large enough to obscure changes resulting from radiation damage annealing.) The fractional recovery at each annealing temperature is shown in Figure 33(a). The differential thermograms obtained at each temperature were nearly identical for all the glasses in the test; those obtained with glass 76-68 are typical and are presented in Figure 33(b). It is clear from the results that damage annealing is quite similar for borosilicate glasses over a wide range of compositions. Recovery is complete at $360^{\circ} \mathrm{C}$; and the annealing curve shows no steps, indicating that recovery proceeds in a single stage.

\section{EFFECTS OF TRANSMUTATION ON WASTE FORMS}

A significant fraction of several of the fission products in high-level waste undergo beta decay and are transmuted to different elements with new valence states and atomic radii. Effects of these transmutations on physical properties are not known but could potentially impact the long-term stability of the waste forms. Several of the principal fission products are stable (Mo or $\mathrm{Nd}$ ) or have very long-lived radioactive components ( $\mathrm{Pd}$ or $\mathrm{Zr}$ ) and will have

TABLE 15. Constants A and B in Alpha Decay Damage Expression and Density Change at Saturation

\begin{tabular}{|c|c|c|c|}
\hline $\operatorname{GLASS}^{(a)}$ & A & B & $\begin{array}{c}\triangle P / P \text { AT } \\
\text { SATURATION, } \%\end{array}$ \\
\hline $72-68\left(8 \% \mathrm{~cm}_{2} \mathrm{O}_{3}\right)$ & $10.0 \times 10^{-3}$ & $2.3 \times 10^{-18}$ & $1.0]$ \\
\hline $72-68\left(1 \% \mathrm{~cm}_{2} \mathrm{O}_{3}\right)$ & $8.33 \times 10^{-3}$ & $2.0 \times 10^{-18}$ & 0.83 \\
\hline 72.68 & $1.33 \times 10^{-3}$ & $1.6 \times 10^{-18}$ & 0.13 \\
\hline EUROPEAN GLASS 6G & $-4.36 \times 10^{-3}$ & $2.6 \times 10^{-18}$ & 0.45 \\
\hline LEAD GLASS P - G & $-9.75 \times 10^{-3}$ & $2.8 \times 10^{-18}$ & 0.98 \\
\hline $77-260$ & (b) & (b) & (b) \\
\hline
\end{tabular}

(a) SEE CLARK (1976) FOR GLASS COMPOSITIONS.

(b) DENSITY CHANGE TOO SMALL FOR ACCURATE DETERMINATION. 


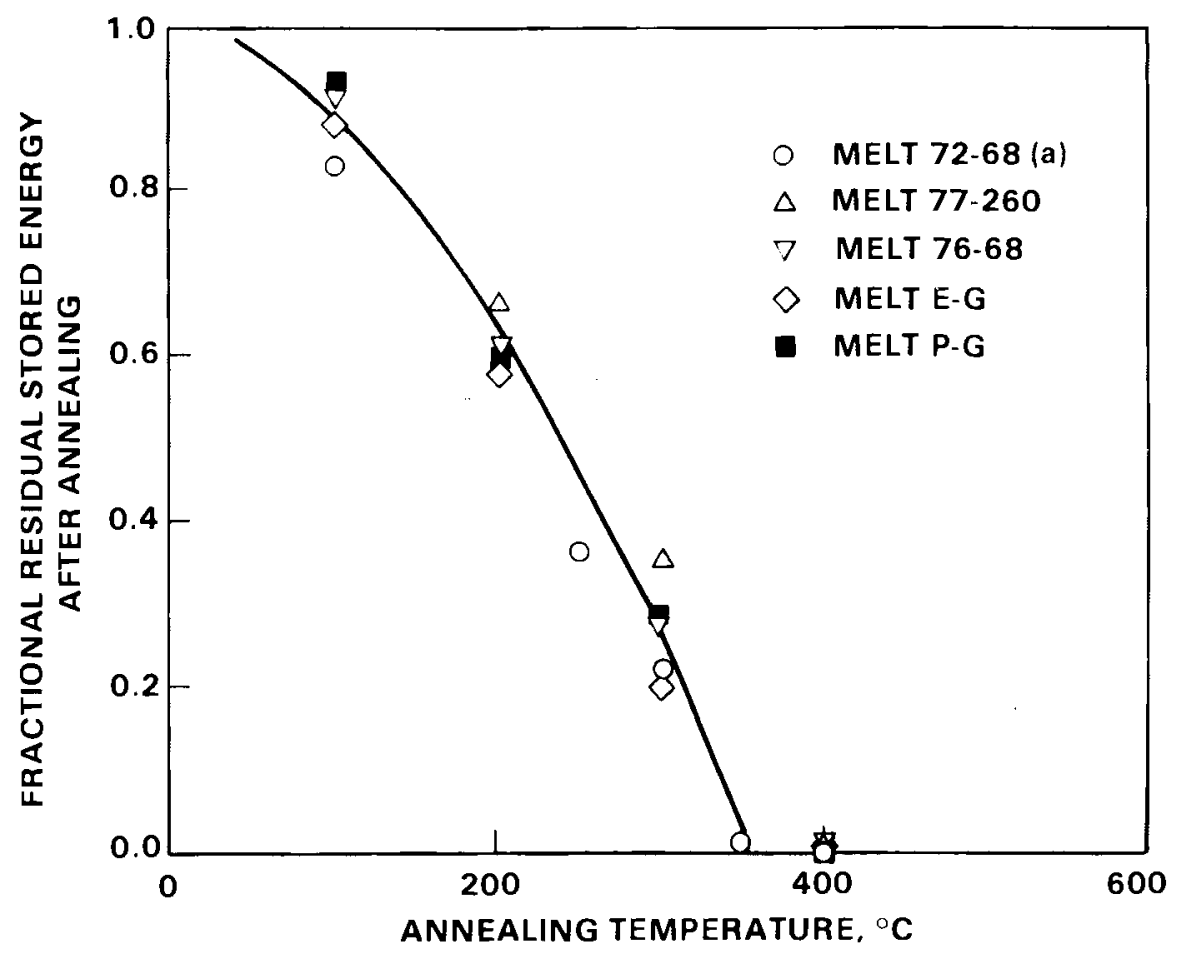

(a) Annealing Behavior of Five Curium-Doped Glasses

FIGURE 33. Recovery from Radiation Damage in Curium-Doped Borosilicate Glasses

Five glasses were doped with curium and allowed to self-irradiate until alpha decay damage reached saturation levels $\left(<6 \times 10^{18}\right.$ alpha decays $\left./ \mathrm{cm}^{3}\right)$. Radiation-induced defects in waste glasses can be eliminated by thermal annealing, which results in a net energy release commonly referred to as stored energy. The magnitude of the stored energy is a measure of the extent of the radiation damage in the material.

All five glasses exhibit nearly identical annealing behavior, Figure (a). Complete recovery occurs at an annealing temperature of $\sim 360^{\circ} \mathrm{C}$ and appears to proceed in a single, continuous stage.

no effect on the waste form. Some (notably $\mathrm{Sr}$ and $\mathrm{CS}$ ) have large relative abundances and radioactive fractions as well as intermediate length lives so that a significantly large change in composition will occur on decay.

Investigation of the effects of transmutation are being carried out in the AWFP using an accelerated approach involving irradiation of simulated waste form specimens in the High-Flux Isotope Reactor (HFIR) at Oak Ridge National Laboratory (ORNL). Because natural cesium is $100 \%{ }^{133} \mathrm{Cs}$ and has a relatively large capture cross section, a substantial fraction is converted to ${ }^{134} \mathrm{Cs}$ in the reactor. This decays to stable Ba with a 2.06-year half-life, thus allowing an accelerated transmutation test. 


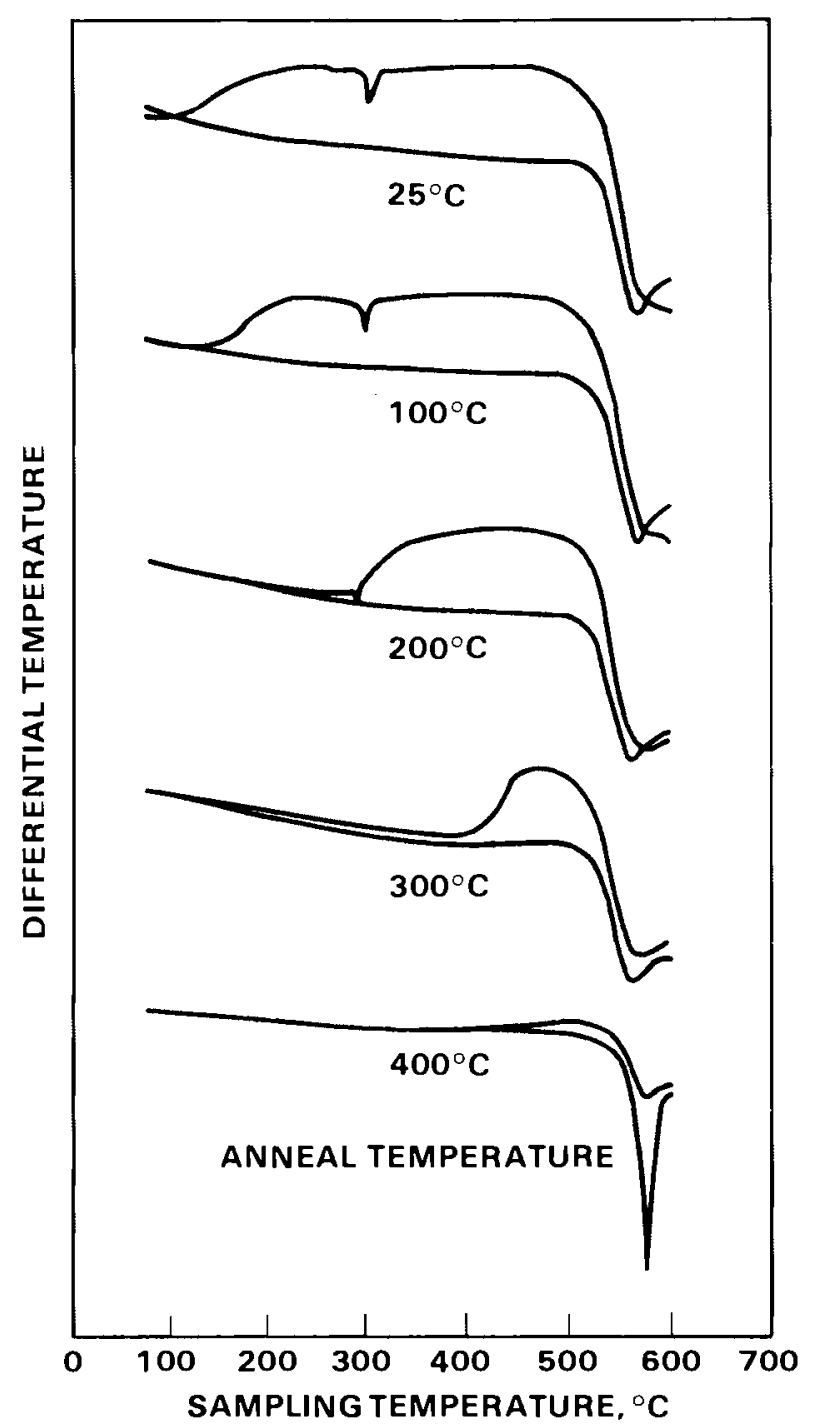

(b) Thermal Behavior of Radiation-Damaged Glasses

FIGURE 33 . contd

The thermal behavior of radiation-damaged glasses is shown by sets of two curves, Figure (b), each of which is a differential thermogram obtained with glass 76-68 samples annealed at five temperatures. The curves are representative of the behavior of all five glasses tested. In each thermogram, the upper curve is the first heating scan, showing the release of stored energy; and the lower curve is a second heating scan, providing a baseline. The area between the two curves is proportional to the amount of stored energy. The endothermic peak at $-300^{\circ} \mathrm{C}$ superimposed on the upper curve is also observed with melts of 77-260 and lead glass $P-G$, but it is not present in unirradiated specimens. The endothermic peak at $\sim 570^{\circ} \mathrm{C}$ is characteristic of all the glasses annealed at $400^{\circ} \mathrm{C}$ including unirradiated specimens. 
Seven simulated waste forms were studied in the test:

- Nominally 76-68 glass with $\mathrm{Cs}_{2} 0$ increased from $\sim 1.0$ to $3.23 \%$ so that the total number of $\mathrm{Cs} \rightarrow \mathrm{Ba}$ transmutations after 4 years decay time would be about equal to those in an actual $76-68$ waste glass after a11 the ${ }^{134} \mathrm{Cs}$ and ${ }^{137} \mathrm{Cs}$ had decayed. The $\mathrm{Cs}_{2} \mathrm{O}$ was substituted for $\mathrm{Na}_{2} \mathrm{O}$ on a molar basis. A sufficient quantity of ${ }^{244} \mathrm{Cm}$ was added so that the ratio of alpha-decay events to Cs transmutations would be about the same as that in actual waste during the first 20 years after solidification (assuming that $1 \%$ of the $\mathrm{U}$ and $\mathrm{Pu}$ remain in the waste stream). The ${ }^{244} \mathrm{Cm}$ was added because the alpha-decay might modify the effects of the CS $\rightarrow \mathrm{Ba}$ transmutations, perhaps by providing the energy necessary for the atoms to rearrange to a more suitable configuration following a transmutation.

- Nominally 76-68 glass except that all the $\mathrm{Na}_{2} \mathrm{O}$ was replaced by $\mathrm{Cs}_{2} \mathrm{O}$ on a molar basis and the amount of $\mathrm{B}_{2} \mathrm{O}_{3}$ was doubled to aid in melting. The large increase in $\mathrm{Cs}_{2} \mathrm{O}$ content was employed so that any effects due to $\mathrm{Cs} \rightarrow \mathrm{Ba}$ transmutations would be more readily detectable than in the glass described above. Again, ${ }^{244} \mathrm{Cm}$ was added so that the ratio of alpha-decay events to $C s \rightarrow B a$ transmutations would be the same as it initially is in actual waste.

- Same as material described above except no actinides were added so that the effect of $\mathrm{CS} \rightarrow \mathrm{Ba}$ transmutations with and without accompanying alpha-decay could be determined.

- An SRL defense waste glass. Composite waste in frit \#411 (comp/411) with 0.91 mole\% $\mathrm{Cs}_{2} \mathrm{O}$ substituted for part of the $\mathrm{Na}_{2} \mathrm{O}$.

- A Hanford defense waste glass. Rockwell Hanford Operations (RHO) residual liquor waste glass with 0.91 mole\% $\mathrm{Cs}_{2} \mathrm{O}$ substituted for part of the $\mathrm{Na}_{2} \mathrm{O}$. This glass and the SRL glass were included to observe the effect of glass composition on transmutation behavior.

- Pollucite $\left(\mathrm{CsAlSi}_{2} \mathrm{O}_{6}\right)$. Pollucite is the principal cesium-bearing phase of several proposed ceramic waste forms.

- Supercalcine (SPC-2 formulation). Supercalcine was included as a representative crystalline waste form.

About 20 specimens of each material were irradiated in HFIR for 4 cycles (95 days) and discharged in April 1979. The materials were then annealed to remove neutron damage effects. Postirradiation testing is now underway and includes $x$-ray diffraction and microscopy (being done at $O R N L)$ as well as leach testing and density measurements. Only preliminary results are available at this time. Final results will be published in subsequent reports. 
Beall, G. H., and H. L. Ritter. 1976. "Basalt Glass Ceramics." Ceramic Bulletin 55:579.

Bradbury, B. T., and B.R.T. Frost. 1967. "Radiation Effects in Ceramic Fuels." In Studies in Radiation Effects on Solids. Vol. 2, p. 159. Gordon and Breach, New York.

Bradley, D. J., C. 0. Harvey, and R. P. Turcotte. August 1979. Leaching of Actinides and Technetium from Simulated High-Level Waste Glass. PNL-3152, Pacific Northwest Laboratory, Richland, Washington.

Bradley, D. J., G. L. McVay, and D. G. Coles. May 1980. Leach Test Methodology for WRIT. PNL-3326, Pacific Northwest Laboratory, Richland, Washington.

Bryan, G. H., and C. R. Palmer. 1980. "Characteristics of Some Transuranium-Contaminated Solid Wastes." In Trans. Am. Nucl. Soc. 34:397-398, Las Vegas, Nevada, June 9-12, 1980.

Bunne11, L. R. 1979. Tests for Determining Impact Resistance and Strength of Glass Used for Nuclear Waste Disposal. PNL-2954, Pacific Northwest Laboratory, Richland, Washington.

Clark, D. W., et al. 1976. "Aqueous Corrosion of Soda Silica and Soda-Lime Silica Glass." J. Am. Ceram. Soc. 59:1-2.

Clark, D. W., C. G. Pantano, Jr., and L. L. Hench. 1979. Corrosion of Glass. Magazines for Industry, New York.

Douglas, R. W., and T.M.M. El-Shamy. 1967. "Reactions of Glasses with Aqueous Solutions." J. Am. Ceram. Soc. 50(1):1-7.

Fullman, H. T. 1979. "Ceramic Materials." In Quarterly Progress Report - Research and Development Activities - High-Level Waste Immobilization Program: April through June 1979, eds. J. L. McElroy et a1. PNL-3050-2, Pacific Northwest Laboratory, Richland, Washington.

Grandstaff, D. E. 1976. "A Kinetic Study of the Dissolution of Uraninite." Economic Geology $71: 1493$.

Gray, W. J. 1980. "Reaction of Graphite with Water and Its Implications for Radioactive Waste Storage." Radioactive Waste Management 1:105.

Hurtgen, C., and J. Fuger. 1977. "Self-Irradiation Effects in Americium 0xides." Inorg. Nucl. Chem. Letters 13:179.

Katayama, Y. B., D. J. Bradley, and C. O. Harvey. March 1980. Status Report on LWR Spent Fuel IAEA Leach Tests. PNL-3173, Pacific Northwest Laboratory, Richland, Washington.

Lutze, W., J. Borchardt, and A. K. De. 1979. "Characterization of Glass and Glass Ceramic Nuclear Waste Forms." In Scientific Bas is for Nuclear Waste Management, ed. G. J. McCarthy. Plenum Press, New York.

Marion, R. H., and J. K. Johnstone. July 1975. A Parametric Study of the Diametral Compression Test for Ceramics. SAND-75-0347, Sandia Laboratories, Atbuquerque, New Mexico.

May, R. P. 1979. "Phase Behavior Studies." In Quarterly Progress Report - Research and Development Activity - Waste Fixation Program, JuTy-September 1979. PNL-3050-3, Pacific Northwest Laboratory, Richland, Washington.

McElroy, J. L. May 1979. Quarterly Progress Reports - Research and Development Activities High-Level Waste Immobilization Program: January-December 1978. PNL-2999-1,2,3,4, Pacific Northwest Laboratory, Richland, Washington.

Mendel, J. E., and W. A. Ross. April 1974. The Chemical Durability of Glasses Containing Radioactive Fission Product Waste. BNWL-SA-4845, Pacific Northwest Laboratory, Richland, Washington. 
Mendel, J. E. 1978. The Storage and Disposal of Radioactive Waste as Glass in Canisters. PNL-2764, Pacific Northwest Laboratory, Richland, Washington.

Mendel, J. E., et al. 1977. Annual Report on the Characteristics of High-Level Waste Glasses. BNWL-2252, Pacific Northwest Laboratory, Richland, Washington.

Mende 1, J. E., et al. 1975. A Program Plan for Comprehensive Characterization of Solidified High-Level Wastes. BNWL-1940, Pacific Northwest Laboratory, Richland, Washington.

Mosley, W. C. 1971. "Self-Radiation Damage in Curium-244 0xide and Aluminate." J. Amer. Ceram. Soc. $54: 475$.

Mularie, W. M., W. F. Furth, and A.R.C. Westwood. 1979. "Influence of Surface Potential on the Kinetics of Glass Reactions with Aqueous Solutions." J. Materials Science 14:2659.

Noe, M., and J. Fuger. 1977. "Self-Radiation Effects on the Lattice Parameter of $244 \mathrm{CmO}_{2} \cdot "$ Inorg. Nucl. Chem. Letters 7:421.

Platt, A. M., and J. A. Powell. June 1980. Nuclear Waste Management Quarterly Progress Report January-March 1980. PNL-3000-5, Pacific Northwest Laboratory, Richland, Washington.

Ross, W. A., and J. E. Mendel. December 1979. Annual Report on the Development and Characterization of Solidified Forms for High-Level Wastes: 1978. PNL-3060, Pacific Northwest Laboratory, Richland, Washington.

Ross, W. A., et al. June 1978. Annual Report on the Characterization of High-Level Waste Glasses. PNL-2625, Pacific Northwest Laboratory, Richland, Washington.

Ross, W. A. 1978. Development of Glass Formulations Containing High-Level Nuclear Waste. PNL-2481, Pacific Northwest Laboratory, Richland, Washington.

Ross, W. A. "Process for Solidifying High-Level Nuclear Waste," U.S. Patent 4,094,809, June 13,1978 .

Rusin, J. M. September 1980. Applicability of Alternative Waste Forms for Immobilization of Alternative Fuel Cycle Wastes. PNL-2775, Pacific Northwest Laboratory, RichTand, Washington.

Rusin, J. M., W. J. Gray, and J. W. Wald. August 1979. Multibarrier Waste Forms, Part II: Characterization and Evaluation. PNL-2668-2, Pacific Northwest Laboratory, Richland, Washington.

Sanders, D. M., and L. L. Hench. 1973. "Mechanisms of Glass Corrosion." J. Am. Ceram. Soc. 56(7): 373-377.

Spriggs, R. M., L. A. Brissette, and T. Vasilos. May 1964. "Tensile Strengths of Dense Polycrystalline Ceramics by the Diametral-Compression Test." Materials Research and Standards, p. 218.

Sun, K. H. 1947. "Fundamental Condition of Glass Formation." J. Am. Ceram. Soc. 30:277.

Takamori, T., and M. Tomazawa. 1978. "HCl Leaching Rate and Microstructure of PhaseSeparated Borosilicate Glasses." J. Am. Ceram. Soc. 61:509.

Tomozawa, M., et al. May 1979. "Phase Separation in Nuclear Waste Glasses." In Proceedings of International Symposium on Ceramics in Nuclear Waste Management, eds. T. D. Chikalla and J. E. MendeT, Cincinnati, Ohio.

Tomozawa, M., and R. H. Doremus. 1979. Treatise on Materials Science and Technology. Academic Press, Inc., New York, $17(2): 41$.

Turcotte, R. P. 1976. "Alpha Radiation Damage in Actinide Dioxides." In Plutonium 1975 and Other Actinides, eds. H. Blank and R. Linder, P. 851. North Holland Publishíng Co., Amsterdam. 
Turcotte, R. P., W. J. Weber, and F. P. Roberts. 1980. "Radiation Damage in Crystalline High-Level Waste Solids." PNL-SA-8196, presented at the 10th International Symposium on Effects on Radiation on Materials, June 3-5, 1980, Savannah, Georgia.

Van Vlack, L. H. 1964. Physical Ceramics for Engineers. Addison-Wesley Publishing Co., Reading, Massachusetts, pp. 59-67.

Weed, H. C., et al. 1979. "Leaching Characteristics of Actinides from Simulated Reactor Waste Glass." Symposium on Science Underlying Radioactive Waste Management, Boston, Massachusetts, November 28-December 1, 1978. UCRL-81147, Lawrence Livermore Laboratory, Berkely, California.

Westsik, J. H., Jr., and R. P. Turcotte. September 1978. Hydrothermal Reactions of Nuclear Waste Solids: A Preliminary Study. PNL-2759, Pacific Northwest Laboratory, Richland, Washington.

Westsik, J. H., Jr., J.W. Shade, and G. L. McVay. 1979. "Temperature Dependence of Hydrothermal Reactions in Waste Glasses and Ceramics." In Scientific Bas is for Nuclear Waste Management, Vol. 2. Plenum Press, New York.

Westsik, J. H., Jr., and C. O. Harvey. 1980. High-Temperature Leaching of a Simulated High-Level Waste Glass. PNL-3172, Pacific Northwest Laboratory, Richland, Washington.

Zachiarasen, W. H. 1932. "The Atomic Arrangement in Glass." J. Amer. Chem. Soc. 54:3841.

Ziegler, D. L., et al. 1977. Status Report: Waste Incineration and Fixation for Waste Management, Production and Reprocessing Division of the Department of Energy. RFP-2655, Rockwell International, Rocky Flats Plant, Golden, Colorado. 


\section{DISTRIBUTION}

No. of

Copies

OFFSITE

UNITED STATES

A. A. Churm

D0E Chicago Patent Group

9800 South Cass Avenue

Argonne, IL 60439

16 DOE Office of Nuclear Waste

Management

NEW, B-107, HQ

Washington, DC 20545

ATTN: C. R. Cooley

G. H. Daly (2)

J. E. Dieckhoner

W. Eister

C. H. George

C. A. Heath

M. L. Lawrence

D. J. McGoff

S. Meyers/R. Romatowski

G. Oertel

A. F. Perge

R. W. Ramsey, Jr.

J. Turi

D. L. Vieth

R. D. Walton

R. E. Cunningham

Office of Nuclear Safety Materials and Safeguards

Nuclear Regulatory Commission

7915 Eastern Avenue, Room 562

Silver Springs, MD 20910

3 Division of Waste Management Nuclear Regulatory Commission Washington, DC 20555

ATTN: J. B. Martin

D. M. Rohrer

R. Dale Smith
No. of

Copies

W. E. Mott

DOE Division of Environmental Control Technology

Washington, DC 20545

S. A. Mann

DOE Chicago Operations and Regional Office

Argonne, IL 60439

J. Neff

DOE Columbus Program Office

505 King Avenue

Columbus, $\mathrm{OH} 43201$

5 DOE Idaho Operations Office

550 2nd Street

Idaho Falls, ID 83401

ATTN: K. A. Carlson

J. P. Hamric

J. W. Peel

J. B. Whitsett (2)

2 S. G. Harbinson

DOE San Francisco Operations

1333 Broadway

Oakland, CA 94612

2 DOE Albuquerque Operations Office P.0. Box 5400

Albuquerque, NM 87185

ATTN: R. Y. Lowrey

A. L. Taboas

2 DOE Oak Ridge Operations Office P.0. Box E

Oak Ridge, TN 37830

ATTN: S. W. Ahrends

D. Large 
No. of

Copies

5 DOE Savannah River Operations Office P.0. Box A Aiken, SC 29801

ATTN: E. S. Goldberg (2)

T. B. Hindman

R. P. Whitfield

B. Wilson

27 DOE Technical Information Center

3 A. L. Lotts

Oak Ridge National Laboratory

P.0. Box $X$

Oak Ridge, TN 37830

4 Oak Ridge National Laboratory

P.0. Box $Y$

Oak Ridge, TN 37830

ATTN: R. E. Blanco

J. 0. Blomeke

D. E. Ferguson

R. S. Lowrie

Los Alamos Scientific Laboratory

P.0. Box 1663

Los Alamos, NM 87544

3 Exxon Nuclear Idaho

P.0. Box 2800

Idaho Fal1s, ID 83401

ATTN: G. L. Ritter

R. A. Brown

File Copy

G. B. Levin

EG\&G Idaho, Inc.

P.0. Box 1625

Idaho Fal1s, ID 43415

2 Allied-General Nuclear Services

P.0. Box 847

Barnwel1, SC 29812

ATTN: J. A. Buckham

A. Williams
No. of

Copies

3 Argonne National Laboratory 9700 South Cass Avenue Argonne, IL 60439

ATTN: J. H. Kittel (2)

M. J. Steindler/

L. E. Trevorrow

7 Battelle Memorial Institute

Office of Nuclear Waste Isolation

505 King Avenue

Columbus, $\mathrm{OH} 43201$

ATTN: A. Brandstetter

W. Carbiener

N. E. Carter

J. 0. Duguid

P. L. Hofmann

M. Kehnemuyi

Beverly Rawles

3 Rockwel1 International

Rocky Flats Plant

P. 0 . Box 464

Golden, C0 80401

ATTN: W. S. Bennett Lawrence J. Smith

E. Vejvoda

2 A. B. Martin Rockwell International 8900 DeSoto Avenue

Canoga Park, CA 91304

12 E. I. du Pont de Nemours and $\mathrm{Co}_{0}$, Inc.

Savannah River Laboratory

Aiken, SC 29801

ATTN: W. H. Baker

M. D. Boersma

J. L. Crandal1

R. G. Garvin (3)

J. Howel

H. L. Hul1

J. A. Kelley

A. S. Jennings

M. P. McGahee

D. L. McIntosh

R. Maher 
No. of

Copies

L. W. Meyer

S. Mirshak

J. K. Okeson

P. H. Permar

M. S. Plodinec

G. Wicks

R. Williams

Electric Power Research Institute 3412 Hillview Avenue

P.0. Box 10412

Palo Alto, CA 94304

Environmental Protection Agency

Technological Assessment Division (AW-559)

Office of Radiation Programs

U.S. Environmental Protection Agency

Washington, DC 20460

R. G. Barnes

General Electric Company

175 Curtner Avenue

(M/C 160)

San Jose, CA 95125

L. H. Brooks

Gulf Energy and Environmental Systems

P.0. Box 81608

San Diego, CA 92138

C. J. Kershner

Monsanto Research Corporation

Mound Laboratory

P.0. Box 32

Miamisburg, $\mathrm{OH} 45342$

J. P. Duckworth

Plant Manager

Nuclear Fuels Services, Inc.

P.0. Box 124

West Valley, NY 14171
No. of

Copies

J. L. Larocca, Chairman

Engineering Research and Development Authority

Empire State Plaza

Albany, NY 12223

3 J. D. Tewhey

Lawrence Livermore Laboratory

P.0. Box 808

Livermore, CA 94550

4 Sandia Laboratories

Albuquerque, NM 87185

ATTN: D. R. Anderson

0 . E. Jones

R. G. Kepler

W. Weart

J. W. Barlett

The Analytical Sciences Corp.

6 Jacob Way

Reading, MA 01867

J. R. Potter

Chem-Nuclear Systems, Inc.

P.0. Box 1866

Bellevue, WA 98009

R. G. Post

College of Engineering

University of Arizona

Tucson, AZ 85721

L. L. Hench

Dept. of Materials Science and Engineering

University of Florida

Gainesville, FL 32611

H. Palmour, II I

2140 Burlington Engineering Laboratories

North Carol ina State University

Raleigh, NC 27607 
No. of

Copies

W. Tope

Westinghouse Electric Corporation

Penn Center, Bldg. 2

Box 355

Pittsburgh, PA 15230

R. Roy

202 Materials Research Laboratory

University Park, PA 16802

F. K. Pittman

3508 Sagecrest Terrace

Ft. Worth, TX 76109

John Pomeroy

Technical Secretary

National Academy of Sciences

Committee of Radioactive Waste

Management

National Research Council

2101 Constitution Avenue

Washington, DC 20418

J. R. Berreth

Allied Chemical Corporation

550 Second Street

Idaho Falls, ID 83401

R. C. Ewing

University of New Mexico

A1buquerque, NM 87131

D. J. Hotaling

Penberthy Electromelt International, Inc.

631 South 96 Street

Seattle, WA 98108

L. Penberthy

Penberthy Electromelt

International, Inc.

631 South 96 Street

Seattle, WA 98108
No. of

Copies

ONSITE

8 DOE Richland Operations Office

E. A. Bracken

P. A. Craig

0. J. Elgert

R. E. Gerton

H. E. Ransom

J. J. Schreiber

M. W. Shupe

M. J. Zamorski

14 Rockwell Hanford Operations

H. Babad

L. C. Brown

R. A. Deju

R. J. Gimera

D. R. Gustavson

B. A. Higley

E. J. Kosiancic

M. J. Kupfer

C. M. Manry

R. A. Palmer

I. E. Reep

J. H. Roecker

D. D. Wodrich

File Copy

United Nuclear Industries

T. E. Dabrowski

Westinghouse Hanford Company

A. G. Blasewitz

107 Pacific Northwest Laboratory

R. P. Allen/H. W. Arrowsmith

R. L. Rodzinski

B. 0. Barnes

W. J. Bjorklund

H. T. Blair

W. F. Bonner

C. Q. Buckwalter 
Pacific Northwest Laboratory (cont'd) M. D. Merz

D. J. Bradley

J. L. Buelt

L. L. Burger

L. L. Cadwell

D. B. Cearlock

L. A. Chick (20)

T. D. Chikalla

J. F. Cline

M. 0 . Cloninger

R. L. Dillon

L. R. Dodd

F. H. Dove

H. Drucker

S. K. Edler

C. E. Elderkin

J. W. Finnigan

R. M. Fleischman

J. A. Franz

J. J. Fuquay

G. W. Gee

W. J. Gray

C. R. Hann

M. S. Hanson

J. N. Hartley

A. J. Haverfield/W. R. Wiley

O. F. Hill

J. H. Jarrett

A. B. Johnson, Jr.

T. L. Jones

Y. B. Katayama

D. E. Knowlton

M. R. Kreiter

L. T. Lakey

D. E. Larson

J. M. Latkovich

R. C. Liikala

R. 0. Lokken

R. P. Marshall

R. P. May

J. L. McElroy

R. W. McKee

G. L. McVay

G. B. Mellinger

J. E. Mendel
I. C. Nelson

R. D. Nelson

J. M. Nielsen/R. W. Perkinds

R. E. Nightingale

D. E. Olesen

C. R. Palmer

P. J. Pelto

A. M. Platt (3)

W. A. Ross

J. A. Powell

R. E. Rhoads

F. P. Roberts

J. V. Robinson

J. M. Rusin

R. J. Serne

J. W. Shade

D. M. Strachan

A. M. Sutey

G. L. Tingey

R. P. Turcotte

C. M. Unruh

H. H. Van Tuyl

J. W. Wald

E. C. Watson

W. J. Weber

J. H. Westsik

M. K. White

R. D. Widrig

L. D. Williams

Technical Information (5)

Publishing Coordination (2) 


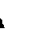

. 